
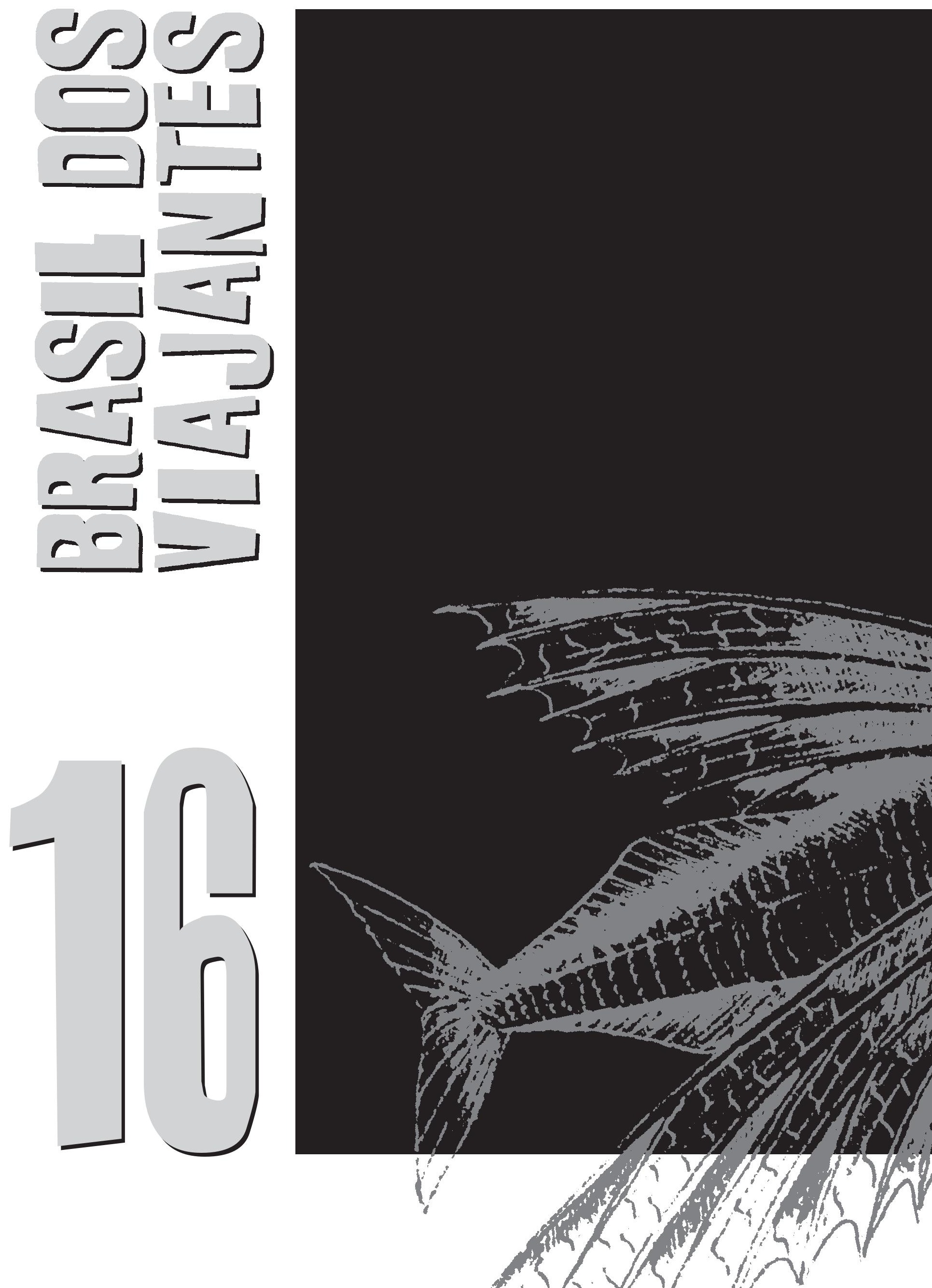
P. E. VANZZ LIN I

\section{A CONTRIBUIÇÃO ZOOLÓGICA \\ DOS PRIMEIROS \\ NATURALISTAS \\ VAJANTES \\ NO BRASIL}




\section{INTRO DUÇÃ O}

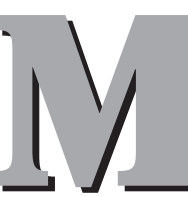

eu tema é a contribuição subs tantiva dos primeiros viajan tes científicos no Brasil para o progresso da Zoologia, tanto sob o aspecto faunístico quanto no campo da sistemática acima do nível de espécie.

Considero substantivas as contribuições intencionais e ponderáveis. Não incluo os inúmeros naturalistas que fizeram coletas incidentais, cujo navio escalou por alguns dias na Bahia, no Rio de Janeiro ou em Florianópolis - embora Darwin ele mesmo tenha coletado uma espécie nova de lagarto no Rio. Levo apenas em conta expedições projetadas e realizadas com o fim precípuo de explorar a fauna brasileira. Incluo apenas um naturalista residente, Marcgrave, por ser o primeiro, e o único pré-lineano. Deixo de incluir outro residente, Lund, porque o tipo de informação que obteve é sui generis, muito diferente (e nisso vejo, aliás, muita grandeza) do que resultava das expedições convencionais. Lund, com Warming, Reinhardt e Winge, é um fenômeno único, idiossincrático, que até hoje não foi devidamente compreendido. Não cabe em uma análise comparativa de sedimentação de conhecimento.

Cinjo-me à zoologia de vertebrados. Éeste o campo que se desenvolvia rapidamente ao tempo dos viajantes cuja contribuição foi significante. Assim, omito Wallace e Bates, com suas esplêndidas coleções de insetos e com suas idéias teóricas revolucionárias - que não têm a ver com Zoologia propriamente dita. Omito Auguste de Saint-Hilaire por ser botânico; embora tenha tido grande visão ecológica, e coletado um pouco, suas coleções não tiveram personalidade suficiente para causar impacto na profissão. Omito d'Orbigny. Trabalhou próximo ao Brasil, mas em outro contexto faunístico; é um autor andino-patagônico, extratropical.

Por razões de certa forma análogas às que causaram estas omissões, incluo duas expedições de importância zoológica muito pequena, a de Langsdorff e a de Agassiz. Essas expedições adquiriram no meio leigo importância tão desproporcional à sua contribuição real que é útil examiná-las sob um ponto de vista mais profissional.

Começo analisando brevemente o estado da Zoologia como ciência no nosso período. Por acordo unânime de seus praticantes, considera-se que a Zoologia Sistemática como disciplina começou com a publicação dos trabalhos de Lineu no século XVIII, resumidos e cristalizados na décima edição do Systema Naturae, de 1758, e estendidos à décima segunda, a última publicada em vida de Lineu.

O Systema, compendiando, de maneira efetiva e original, toda a História Natural do tempo, e implantando o sistema extremamente prático da nomenclatura binominal, determinou uma como que homogeneização do conhecimento zoológico europeu e, assim, um patamar para o progresso da ciência: bem delimitadas as fronteiras do conhecido, tornavase fácil cruzá-las pela simples exploração geográfica de um mundo em boa parte por descobrir. Assimo Systema Naturae, como toda obra seminal, criou as condições para sua própria ultrapassagem, e isso especialmente por intensa atividade faunística, conjugada com a acelerada exploração geográfica, envolvendo muitas viagens de circunavegação no fim do século XVIII e começo do XIX.

O primeiro quartel do século XIX viu o início da exploração científica intensiva, profissionalizada, do Novo Mundo (Papavero, 1971-73). No caso do Brasil, a entrada de pesquisadores foi retardada pela política exclusivista de Portugal (Vanzolini, 1981). A fuga, porém, da família real portuguesa, acossada pelos exércitos napoleônicos, para o Brasil em 1810, tendo, como conseqüências imediatas, a abertura dos portos e a vinda de ponderável corpo diplomático, abriu o território a pesquisadores europeus.

Em 1817 o príncipe herdeiro Dom Pedro (mais tarde Primeiro) casou-se, por procuração, com a arquiduquesa imperial da Áustria, D. Leopoldina. Esta veio para o Brasil em fins do mesmo ano, trazendo em seu séquito uma boa comissão científica, selecionada por E. Schreiber, diretor do Museu de Viena (Ramirez, 1968). Esse evento marca, tanto oficialmente quanto na realidade, o início da atividade profissional zoológica no Brasil. Antes de entrar, porém, na história, há dois precursores a con- pesquisador diretor do Museu de Zoologia da USP. 
siderar: Georg Marcgrave no século XVII e Alexandre Rodrigues Ferreira no XVIII.

\section{OS PRECURSORES}

\subsection{Georg Marcgrave}

Marcgrave, ou Marcgraf, nascido na Saxônia em 1610, veio para o Brasil em 1638, participando do plano de governo de Maurício de Nassau para o Brasil holandês. Veio como astrônomo: para ele fez Maurício construir o primeiro observatório do Novo Mundo. Sua obra astronômica, dita considerável, parece ter-se perdido na quase totalidade (Taunay, 1942) - Marcgrave passou à posteridade por seu trabalho, para ele mesmo aparentemente secundário, de naturalista. Escreveu um dos volumes de uma História Natural do Brasil; o volume companheiro foi escrito por Willem Pies ("Piso"). Marcgrave não viveu para ver sua obra publicada; viajando para a África a serviço, morreu em Angola em 1644. O livro foi publicado por seu amigo, o belga Johannes de Laet, sob o título Historia Naturalis Brasiliae, em Leiden e Amsterdã, em 1648.

É uma lista de animais (245 espécies de vertebrados), contendo o nome vulgar em tupi ou português, ou ambos, uma descrição ao gosto da época e numerosas ilustrações.

Até o começo do século XIX os métodos de preparação e armazenagem de exemplares zoológicos estavam na infância, e as coleções zoológicas constituíam-se em grande parte de pinturas executadas, quando possível, de modelos vivos. A publicação dessas ilustrações era difícil e cara, e por isso nas obras da época elas eram substituídas por xilogravuras. No caso de Marcgrave, as ilustrações constam de xilografias abertas na Holanda, copiando originais a aquarela ou óleo feitos no Brasil. Os originais são magníficos; há debate sobre sua autoria (Taunay, 1942; Albertin, 1985). As xilografias, ao contrário, são cruas. É de fato chocante o constraste entre a gravura em talha doce, opulenta e barroca, da página de rosto da História Natural, e as xilografias, duras, reminiscentes das ilustrações do século XV (Febvre e Martin, 1992). Muitas delas, po- rém, permitem identificação inequívoca, especialmente nos casos em que os contornos do corpo são característicos (por exemplo, peixes - Günther, 1880).

Marcgrave era, como dito, astrônomo. Embora tivesse estudado História Natural em Rostock (Taunay, 1942) e fosse observador minucioso, moderado e honesto, falta, como óbvio para a época, caráter profissional ao seu trabalho. Mesmo assim, este é bem superior aos dos contemporâneos frei Christóvão de Lisboa (livro composto de 1624 a 1627, publicado em 1967), sobre fauna do Maranhão e, especialmente, Zacharias Wagener (composto de 1634 a 1641, publicado em 1964). Este também foi funcionário de Maurício de Nassau, era saxão como Marcgrave e escreveu sobre a mesma fauna. Marcgrave, diz Stresemann (1951, p. 36; 1975, p. 34), havia, como viajante científico, adquirido "imorredoura fama". Sua sobrevivência, contudo, deve-se unicamente a Lineu. Na décima edição do Systema Naturae este incluiu 1.370 espécies de vertebrados: Marcgrave é citado a respeito de 39 destas, 14 mamíferos, 15 aves, 2 répteis e 8 peixes. Em todos os casos, menos dois, Marcgrave é citado entre outros autores, inclusive o próprio Lineu, em

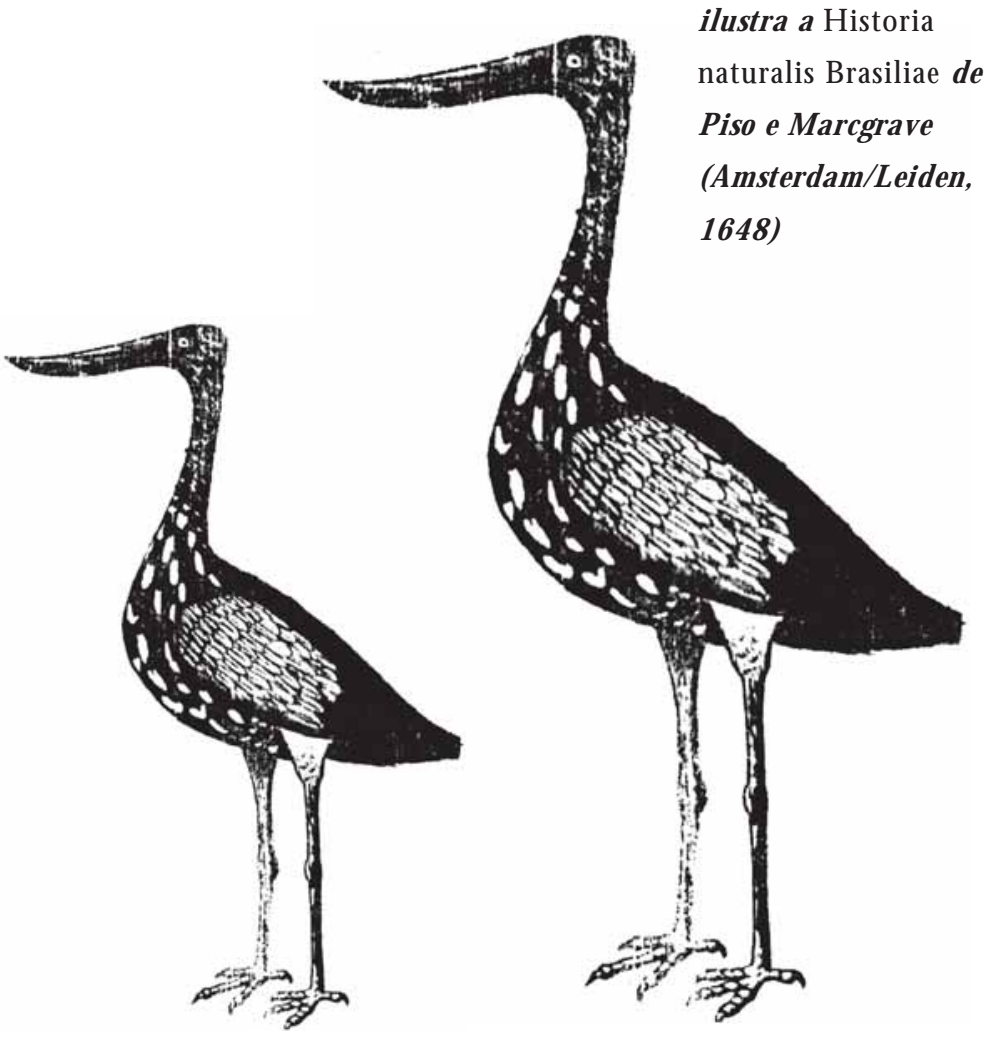

"Jaburu", xilogravura que ilustra a Historia iliae de iso e M arcgrave 1648) 
trabalhos anteriores. Nos dois casos restantes, porém, ele é a única autoridade citada, devendo assim ser considerado responsável pelo conceito lineano da espécie. São elas, o mamíferoLepus brasiliensis (atualmente Sylvilagus, família Leporidae), a lebre ou tapiti, e o peixe Pleuronectes papillosus (agora Syacium), um linguadinho da família Bothidae.

Depois disso Marcgrave caiu no olvido, até que Lichtenstein (1818-26, 1961), descobrindo os originais das ilustrações na Biblioteca de Berlim, atualizou em um longo artigo a identificação das espécies. Levando-se em conta que as formas descritas por Marcgrave são todas comuns, com nomes vulgares firmes, e que as descrições são complementadas por gravuras, compreende-se que nunca tenha havido qualquer dúvida sobre a identidade das espécies marcgravianas, especialmente aquelas referidas por Lineu - as únicas de importância prática. Assim, o trabalho de Lichtenstein vale apenas por levantar do olvido um acervo artisticamente notável. Depois de Lichtenstein, Schneider (1938) apresentou uma excelente nota crítica sobre as estampas e identificou as aves.

Os originais das figuras da História Natural foram vendidos (Rodolfo Garcia, 1922, p. $865)$ por Maurício de Nassau a seu parente Friedrich Wilhelm, Grande Eleitor de Brandemburgo, na biblioteca de quem foram organizados pelo médico Christian Mentzel em quatro volumes, Icones Aquatilium, Icones Volatilium, Icones Animalium e Icones Vegetabilium. Eventualmente foram parar entre os Libri Picturati da Biblioteca de Berlim, de onde foram apressadamente evacuados durante a Segunda Guerra Mundial, ficando desaparecidos por muitos anos, até que em 1977 o ictiólogo Peter Whitehead descobriu a coleção na Universidade Jagelonsquiana, em Cracóvia. Uma editora brasileira, Index, publicou em 1993 esse Theatrum Rerum Naturalium Brasiliae, sem comentários científicos mas com uma história da recuperação da obra. As figuras são muito bem reproduzidas e têm grande valor artístico.Zoologicamente, porém, como dito, quase nada acrescentam, e praticamente não estão comentadas. Uma discussão técnica dos originais é apresentada por Albertin (1985).

\subsection{Alexandre Rodrigues Ferreira}

O segundo precursor, nascido em Salvador, em 27 de abril de 1756, tomou ordens menores "na muito baixa idade" (Tavares da Silva, 1947) de 12 anos, mas imediatamente abandonou a carreira eclesiástica, abraçando as ciências naturais e doutorando-se, com distinção, em Coimbra, sob a direção de Domenico Vandelli.

Há indícios de que D. Maria I, rainha de Portugal, ou alguém forte em seu governo iluminista, gostava de História Natural e tinha interesse na flora e fauna das colônias (Pinto, 1979, p. 46). Provavelmente por um encontro dessa inclinação com interesses administrativos e diplomáticos (Moreira Neto, 1983), decidiu a corte portuguesa empreender uma expedição ao Brasil. Alexandre foi indicado pela universidade para chefiá-la. Veio para o país no segundo semestre de 1783 , radicando-se em Belém do Pará.

Há diversas biografias de Alexandre (lista em Goeldi, 1982). Apenas uma delas, porém (Corrêa Filho, 1939), obra enfadonha por entusiasta e sacarina, dá indicações claras, confirmadas pelo Roteiro de Alexandre (1933 q.v.i.), sobre as funções desempenhadas pelo naturalista no Pará, de outubro de 1783 a setembro de 1784 , quando partiu para o rio Negro: teriam sido de técnico agrícola, como que um extensionista de hoje, e de inspetor geral do serviço público ("vogal nas Juntas de Fazenda e de Justiça”, Pontes, 1858), sob as ordens do governador João Pereira Caldas. Nessas funções visitou a costa de Marajó fronteira a Belém, a baía de Marajó e o baixo Tocantins. Depois seguiu para o Amazonas e Mato Grosso.

No que segue utilizo, resumidamente, um estudo paralelo a este que fiz, especificamente, do itinerário de Alexandre (Vanzolini, em preparo). De acordo com seu Roteiro partiu ele em 19 de setembro de 1784 para o rio Negro. Fez uma viagem relativamente rápida de Belém a Manaus (147 dias), com algumas poucas digressões, na baía de Portel, no Xingu, no Paru e no Tapajós.

No Amazonas fez base em Barcelos, capital da capitania. Em uma primeira viagem subiu o Negro até a pedra extrema de Cucuí, entrando, 
na ida, nos rios Uaupés, Içana e Xié e, na volta, no Cauaburis, no Padauiri e no Aracá.

Entre parênteses, sempre me pareceu, a julgar pelos itinerários e pelo andamento das viagens, que Alexandre tinha, remando para si, a fina flor da indiada. No entanto, Corrêa Filho (1939) conta que por diversas vezes, eespecialmente no Madeira, Alexandre teve que enfrentar duros problemas (comuns nas viagens longas) de motins e de deserção maciça de remadores e mesmo de soldados.

A viagem seguinte foi ao vale do rio Branco, subindo o Uraricoera (um dos formadores) até um pouco além da Ilha de Maracá. Subiu também o Maú, rio da fronteira guianense, e fez uma viagem a pé pelo "lavrado" de Roraima, a vasta extensão dos chamados "campos do Rio Branco", semelhantes a cerrados (Vanzolini e Carvalho, 1991). Levou na exploração do Branco 88 dias, voltando a Barcelos em 3 de agosto de 1787.

Em agosto de 1787 mudou o teatro de suas operações, de Barcelos para Vila Bela da Santíssima Trindade, do Negro para o alto Guaporé. Levou 378 dias de percurso, tendo entrado por distâncias várias nos rios Aripuanã, Araras (Arauá) e Manicoré.

De Vila Bela viajou por terra às lavras de ouro da Serra de São Vicente e de Poconé e à Chapada dos Guimarães. Essa empresa toda de Mato Grosso tomou dois anos e cinco meses.

A viagem final de Alexandre foi de Cuiabá, rio abaixo, até o Forte de Coimbra, com visita à Caverna do Inferno, e regresso a Vila Bela subindo o Jauru e levando ao todo 102 dias.
Verifica-se assim que fantástica experiência de campo adquiriu Alexandre, homem minucioso e perspicaz, ao longo de seis anos e meio de viagem, dos quais pelo menos quatro e meio passados efetivamente no campo, explorando majoritariamente mata amazônica, mas também uma certa medida de cerrado. As coleções feitas, porém, não foram grandes.

Devemos aqui considerar o problema da missão de Alexandre, que trato em mais detalhe em outro artigo (Vanzolini, em preparo). $\mathrm{O}$ atraente título "viagem filosófica" desde sempre cativou as imaginações, e Alexandre é geralmente considerado um pesquisador puro desempenhando uma tarefa científica. Penso diferente. Não tenho dúvida de que os objetivos das viagens ao Negro e a Mato Grosso eram antes administrativos e estratégicos, ligados a questões de fronteiras e de produção de ouro. O título de "philosophica" pode ter sido em parte um disfarce, em parte complacência com as inclinações de naturalista de Alexandre, e provavelmente correspondia aos intuitos iniciais da coroa portuguesa. Que tenha havido intervenção de burocratas envolvidos na administração direta do projeto (leia-se João Pereira Caldas) é mais que provável. De qualquer maneira, é fato que, durante as viagens, Alexandre coletava e mandava desenhar animais, por seus dois “riscadores", José Joaquim Freire e Joaquim José Codina, ambos razoavelmente competentes.

É óbvio que Alexandre tinha recebido instruções de duas ordens, política e técnica. Sobre a primeira já comentei que fica para

\section{Joaquim Freire \\ ou José Codina, \\ "C rocodilu", \\ desenho aquarelado \\ sobre papel, \\ Fundação Biblioteca \\ $\mathrm{N}$ acional, \\ Río de Janeiro}

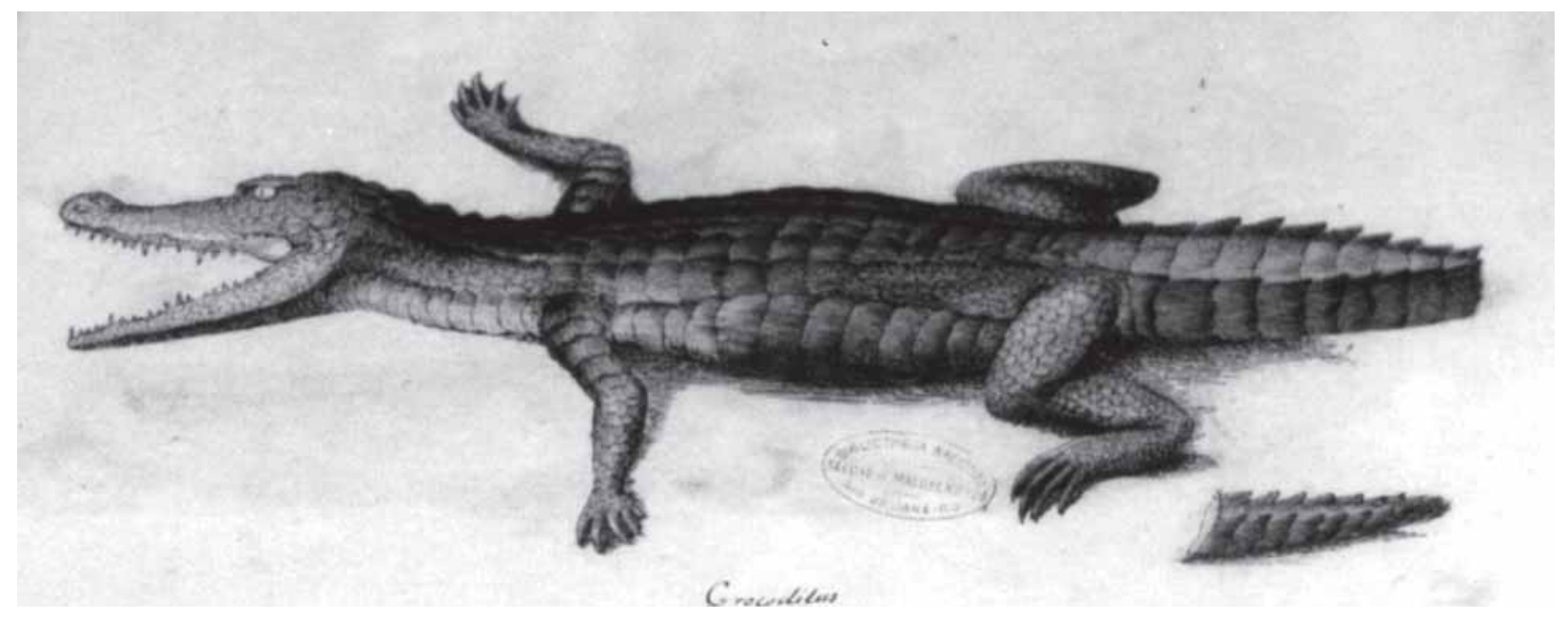


outro artigo (Vanzolini, em preparo). Sobre a parte técnica há uma interessantíssima nota (Mendes, 1946).

As instruções iniciam-se com o que fazer durante a viagem marítima. Os oito primeiros dias (a viagem durava dois meses) seriam de feriado, para acomodação geral, inclusive com o enjôo. Depois disso deveriam os expedicionários dedicar-se à coleta de peixes marinhos, identificando-os ("reduzindo") e desenhando-os. Também, considerando-se o alto investimento da coroa em artes de pesca (linhas, anzóis, etc.), os peixes não poderiam ser desperdiçados, mas sim preparados e conservados para o Real Gabinete.

No caso das viagens por terra (após um mês e meio, início de férias para reacomodação) tudo era estritamente previsto e prescrito: a ordem de marcha (os pretos e índios na frente, para absorverem ataques inesperados), o horário e a qualidade das refeições, o tipo de camas e colchões, etc.

Corrêa Filho (1939) diz que essas instruções, de que viu um manuscrito não assinado, são de autoria do próprio Alexandre. Eu duvido de que um brasileiro nato, homem de bom senso comprovado, prescrevesse para seu próprio uso, em tão impiedoso detalhe, a vida quotidiana de uma expedição de muitas dezenas de índios e vaqueanos no meio de nenhures. Prefiro crer na velha e honrada tradição luso-brasileira de burrice burocrática, interferindo pela primeira vez, mas certamente não pela última, na profissão científica.

As prescrições sobre a feitura e manutenção de diários de campo são também detalhadas e, no geral, sensatas, se bem que ocasionalmente difíceis de entender: "denotar huma Carta Geographica do Paíz em que venhão marcados com sinais chimicos os diferentes minerais e fosseis [...] os habitantes, seus costumes e sua Religião [...] não omitir lugar nenhum beira mar [...]" (Mendes, 1946).

Os materiais coletados eram, na medida das possibilidades, despachados para Lisboa, para o Museu da Ajuda.

Nesse mesmo museu passou Alexandre, de volta a Portugal em 1793, a trabalhar como pesquisador, depois de breve período como oficial administrativo. Sua coleção brasileira, apesar dos anos passados no campo, não era grande. Isso se explica não só por causa das outras funções desempenhadas por ele, mas também pelas próprias limitações da zoologia da época. A ênfase tinha obrigatoriamente que ser posta em peles de mamíferos de tamanho médio, cascos de tartarugas e peças que tais, exigindo pouca delicadeza no preparo e permitindo conservação por via seca.

Relatam os biógrafos que, em Lisboa, Alexandre entrou em progressiva depressão ("fatal melancolia", Pontes, 1858) e que dela faleceu em 1815. O único biógrafo que tentou explicar essa enfermidade foi Corrêa Filho (1939), e não concordo inteiramente com ele.

Alexandre, mostram seus manuscritos remanescentes, planejava publicar sobre todas as suas coleções e apontamentos de campo, zoológicos e etnográficos. O ambiente científico em Portugal era, na época, muito ruim. Com exceção do grande e completo (e muito posterior) José Vicente Barboza du Bocage (1857-1901), nenhum zoólogo português de relevo jamais se ocupou da fauna das colônias. O próprio museu era deficiente quanto a coleções e biblioteca. Corrêa Filho (1939, p. 154) dá para as coleções 96 mamíferos, 1.250 aves (96 do Brasil) e 1.230 peixes. A biblioteca contava com 307 volumes, boa parte dos quais (loc. cit.) de história e literatura. Alexandre lutava para empreender seus estudos, que andavam devagar. Encontram-se na literatura também várias insinuações de que Alexandre teria vida difícil no museu, sofrendo inclusive sabotagem de seus materiais, por inimizade de um colega. Este poderia ter sido o próprio Vandelli (Pires de Lima, 1953, p. 29).

No ano de 1808 , os exércitos napoleônicos, comandados por Junot, invadiram Portugal. Como de costume, acompanhavam o exército alguns savants franceses, encarregados da rapina cultural do país derrotado. Etienne Geoffroy Saint-Hilaire foi o zoólogo que saqueou a Ajuda. (A Grande Encyclopédie Larousse diz que em 1808 Etienne foi encarregado de uma mission scientifique en Espagne et en Portugal.)

Os franceses ao tempo tentavam cobrir com um véu diáfano de legalidade a nudez crua da expropriação: era celebrado um "tratado", trocadas cartas de intenção, dadas ex- 
plicações, passados recibos e mesmo fornecidas duplicatas do Museu de Paris em troca de doações "voluntárias", merecendo assim a admiração dos próprios saqueados (Appel, 1987, p. 92; bárbara coragem ou santa ingenuidade?). De fato, às vezes, a manobra aparentemente funcionava, e os rapinantes acabavam mesmo elogiados por sua moderação e civilidade (Silva Carvalho, 1930, p. 903). Neiva (1929, p. 16) transcreve a ordem de serviço do duque de Abrantes, comandante do exército português, autorizando o museu a retirar das coleções e encaixotar para transporte à França 65 espécies (384 exemplares) de mamíferos, 238 (384) de aves, 25 (32) de répteis e 89 (100) de peixes . Existe um caso idêntico, bem documentado, na literatura: o saque "legalizado" das coleções do Stadholter Guilherme V da Holanda em 1795 (Boeseman, 1930; Pieters, 1980). Para não falar no fantástico saque das antigüidades e história natural do Egito, pelo mesmo Napoleão Bonaparte e seus savants. Mas aí era um país de pretos.

No fim, o material terminava em Paris, bem estudado mas conservado em um museu não muito melhor que a Ajuda, em termos de curadoria.

Até o fim da vida, Etienne Geoffroy SaintHilaire referia-se, com evidentes orgulho e satisfação, a "mon voyage de 1808 au Portugal", do mesmo jeito por que um zoólogo brasileiro poderia referir-se a "minha viagem a Marajó em 1958" - uma maravilhosa oportunidade de coleta. O mesmo orgulho e satisfação revelava o filho e sucessor, Isidore Geoffroy. Foi de fato uma bela excursão, barata e proveitosa.

Não há propósito, a esta altura, em esmiuçar mais este mesquinhoepisódio, mas deve-senotar que há outros exemplos. Schweigger (1812, p. 302), descrevendo a nova espécie Emys geoffroana (hoje Phrynops) diz: "Vidispecimen in museo Parisiensi, quodill. Geoffroy Lisbonae in museo regio collegerat'. Gervais (1855b, p. 90) menciona o exemplar trazido de Lisboa que servia de tipo para Inia geoffrensis, o boto branco ou malhado da Amazônia, originalmente coletado por Alexandre.

Assim, em vez de Alexandre publicar o resultado de suas pesquisas (isto é, à maneira da época, as espécies novas), as novidades foram descritas pelos dois Saint-Hilaire e por Anselme Gaetan Desmarest. Diz E. Geoffroy Saint-Hilaire (1809a) terem sido levados da Ajuda 66 mamíferos e 275 aves; a discrepância entre esta lista e a de Neiva (1929) é pequena, explicável pelas circunstâncias e pela competência das duas instituições envolvidas. Nem tudo, porém, era do Brasil: havia outras colônias no meio. No Catalogue Méthodique da coleção de mamíferos de $\mathrm{Pa}$ ris (I. Geoffroy Saint-Hilaire, 1851) encontramos 18 espécies de macacos como originárias da famosa viagem de 1808 . As seguintes são baseadas em exemplares provavelmente coletados por Alexandre (sinonímia de acordo com Groves, 1993): 1) Saimiri ustus I. Geoffroy, 1843; 2) Cebus cirrifer E. Geoffroy, 1812 = C. apella (L., 1758); 3) Cebusflavus E. Geoffroy, 1812=C. albifrons (Humboldt, 1812); 4) Ateles marginatus E. Geoffroy, 1812; 5) Lagothrix canus E. Geoffroy, $1812=$ L. lagothricha (Humboldt, 1812); 6) Pithecia monachus E. Geoffroy, 1812; 7) Jacchus humeralifer E. Geoffroy, 1812 = Callithrix humeralifer; 8) Jacchus melanurus E. Geoffroy, 1812 = Callithrix argentata (L., 1771); 9) Midas labiatus E. Geoffroy, 1812 = Saguinus labiatus .

Assim, a influência do primeiro naturalista profissional brasileiro no progresso da zoologia pátria foi defletida, passou a indireta, limitada a um único grupo (Primates) e trazendo em si uma história das mais repugnantes. O verdadeiro zoólogo não tem a paixão aguda da novidade. Seu serviço consiste na construção de sistemas simples e lógicos, em que as espécies se insiram com naturalidade e se expliquem mutuamente, dentro de um contexto ecológico e geográfico. Ver esse projeto frustrado, à vista da conclusão, é (pensando como zoólogo) causa suficiente para "melancolia fatal", declínio, misantropia e morte prematura. Essa é a opinião de Corrêa Filho (1939) e também foi a minha, até que o livro de Pires de Lima (1953) atraiu minha atenção para algumas pistas contidas na literatura, sobre problemas médicos anteriores de Alexandre, indicando que a questão não era tão simples.

Em uma carta de 30 de junho de 1784 , 
escrita em Belém, a Martinho de Souza e Albuquerque (Pires de Lima, 1953, pp. 12932), conta Alexandre seus sintomas ("novela que diverte a quem ouve porém aflige a quem figura nella").

"No parecer do Médico do hospital eu não tinha outra coisa mais que melancholia: pelo vóto do Commissario delegado do Proto-Medicáto eu padesso huma cardialgia histerica. [...] No entanto em toda a cidade, pela qual se espalhou que eu não tinha mais que melancholia hum me há tido por scismático, outro por melancholico, e alguns por pateta [...]".

Durante as viagens queixa-se Alexandre continuamente da saúde. A visita à serra dos Cristais, no Rio Branco, havia sido penosa (Pires de Lima, 1953, p. 60). A subida do Madeira e do Guaporé, que durara 13 meses e 18 dias, havia sido muito mais dura ainda; um dos expedicionários morrera ao chegar a Vila Bela (Pires de Lima, 1953, pp. 77-8). A visita à Gruta das Onças, em Mato Grosso, resultara em um longo período de enfermidade para Alexandre (Pires de Lima, 1953, p. 85).

Parece provável, que, ao longo da vida, tenha sofrido Alexandre de uma síndrome de depressão, talvez de pânico. O peso do trauma de 1808 sobre um organismo com tal passado psiquiátrico e tanto depauperamento orgânico deve ter sido com certeza suficiente para desorganizar a sua psique e levá-lo ao alcoolismo e entrevecimento (Pires de Lima, 1953, pp. 22 e 32). O detalhe do alcoolismo realça a relevância da síndrome suspeitada (Lotufo-Neto e Gentil, 1994).

Essa passagem, relatada concisa e dignamente por Pires de Lima (1953), vem sendo cuidadosamente omitida, obviamente por delicadeza, por todos que escrevem sobre Alexandre. Acho um erro. A condição humana não é vergonha; a verdade que não revela desonestidade não enfeia.

\subsubsection{Alexandre Rodrigues Ferreira como zoólogo}

A auto-imagem de Alexandre era a de qualquer sistemata em qualquer tempo: "essa leve tintura que tenho de alguns Estudos Naturaes" (Pires de Lima, 1953, p. 220), ou seja, ele sabe que não sabe nada - e que os colegas sabem menos.

Alexandre obviamente não tinha inclinação para a Ecologia. Passando pelos lugares por onde passou, vendo as paisagens que viu, não tomou uma nota ecológica sequer. Deve ser antes julgado como sistemata, profissão em que não havia sido treinado (Vandelli era muito medíocre), mas para a qual o inclinava seu espírito meticuloso de alistador emérito (inclusive de alfaias de igreja).

Muito da mitologia que cerca Alexandre, obviamente encorajada pelas peculiaridades étnicas e pelos infortúnios da carreira, concerne seu valor como cientista. É ele comumente considerado um gênio frustrado; não conheço, porém, uma avaliação fria de sua qualidade profissional. As pistas que temos para fazê-lo são quatro artigos publicados postumamente e, menos diretamente, a coleção de estampas publicada pelo Conselho Federal de Cultura em 1971 sob o título Viagem Filosófica.

Três artigos, publicados em 1903 nos Archivos do Museu Nacional do Rio de Janeiro (Rodrigues Ferreira, 1903 a-c), com notas de rodapé de Alipio de Miranda Ribeiro, são de pouca importância.

"Sobre o Peixe Pirá-urucu”: curiosamente, uma descrição formal em latim, modelolineano, enxuta, razoável, sem proposta de nome.

"Sobre o Peixe Boy": tem muito pouco conteúdo zoológico, mas mostra um aspecto interessante: ao lado dos usuais comentários, feitos por todos os viajantes, sobre tamanho, amamentação e distribuição geográfica, revela uma preocupação objetiva (característica de Alexandre) com a conservação da espécie, em si e como recurso natural desfrutável.

"Sobre a Yurara-reté": esta é Podocnemis expansa, a tartaruga por excelência da Amazônia, e Alexandre fez com ela o que nenhum viajante jamais deixou de fazer: descreveu a desova, a pesca e o aproveitamento dos ovos. Mas, além disso, também caracteristicamente, deu os primeiros dados estatísticos que se têm da espécie.

"As Pranchas de Animais": o Conselho Federal de Cultura publicou excelentes re- 
produções de 147 pranchas da coleção de Alexandre (Rodrigues Ferreira, 1971). Muitas têm duas figuras, macho e fêmea da espécie ou espécies diferentes. Acompanham um prefácio e uma introdução, ambos um tanto anêmicos, e uma "Explicação das Estampas", que consta apenas de uma lista, não comentada, de identificações e distribuições geográficas generalizadas.

Como projeto de ilustração faunística a escolha das espécies é, no geral, muito razoável: Alexandre, afinal, era um zoólogo. De mamíferos são representadas 50 espécies: 1 marsupial, 16 macacos, 5 xenartros, 12 carnívoros, o peixe-boi, 3 ungulados, 10 roedores e 2 cetáceos (os botos de água doce). Sentese falta apenas de morcegos. Nas aves (50 espécies), 29 famílias estão representadas, das 73 possíveis; a distribuição é muito boa. A representação dos répteis é muito fraca: são animais que na maioria se conservam por via úmida. São citados 3 lagartos, 1 anfisbênio, 1 jacaré e 5 quelônios, incluindo um exemplar bicéfalo de tracajá (Podocnemis unifilis, Pelomedusidae). Não há nenhum anfíbio (de novo o problema da conservação em álcool). Há 58 espécies de peixes fluviais e 7 de peixes marinhos. Os invertebrados, na maneira da época, são representados por 4 insetos (incluindo larvas e um ninho de vespas), um quilópodo um molusco (o turu, Teredinidae).

Cabe aqui uma indagação sobre a procedência geográfica dos exemplares, não explicitada nas figuras e não registrada no Museu da Ajuda. Em um trabalho paralelo a este, sobre as viagens de Alexandre (Vanzolini, em preparo), eu me perguntava sobre a verdadeira missão do naturalista: era a intenção "filosófica" real e primacial, ou, pelo menos em parte, pretexto e disfarce para outras atividades, administrativas e diplomáticas. A lista de animais permite uma verificação indireta. Alexandre demorou 29 meses em Mato Grosso: o que e quanto teria coletado aí? Há na lista de animais 9 espécies que são decididamente extra-amazônicas, restritas a formações abertas - no caso, o cerrado. Entre os répteis, o lagarto Hoplocercus spinosus (Hoplocercidae), o conhecido cuviara, e a sucuri da bacia do Paraguai, Eunectes notaeus (Boidae). Entre as aves há

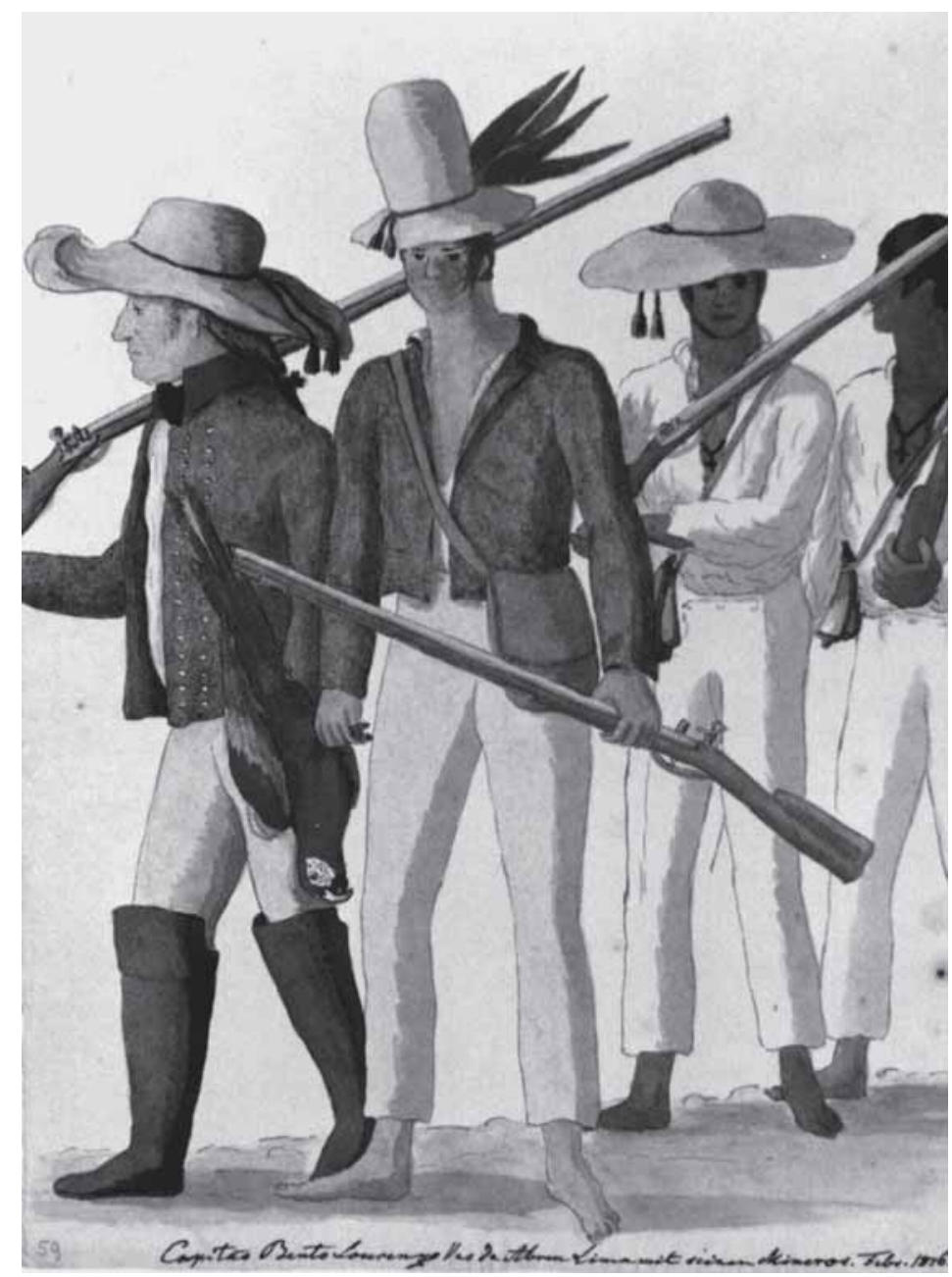

algumas notórias: a ema (Rhea americana, Rheidae), o nhambu-chintã (Crypturellus tataupa, Tinamidae), a perdiz (Rhynchotus rufescens, Tinamidae), a tachã (Chauna torquata, Anhimidae) e a seriema (Cariama cristata, Cariamidae). Entre os mamíferos, o sagüi Callithrix penicillata (Callithrichidae) e o lobo guará (Chrysocyon brachyurus, Canidae). Nove espécies em 115: Alexandre andou por Mato Grosso, mas não coletou muito. Outras coisas terá feito.

Quantoà execução, as estampas sãono geral de valor mediano. Há algumas muito boas (especialmente peixes), outras muito ruins: a do lobo guará, justamente uma das espécies roubadas de Alexandre, é simplesmente horrível. O tatu-peba está mal desenhado e mal identificado (tanto nas estampas quanto na Explicação do Conselho Federal de Cultura): não é um peba, é um galinha - Dasypus e não Euphractus.
Prinz Maximilian zu Wied-N euwied, "C apitão Bento Lourenzo Vas de

Abreu Lima", aquarela sobre papel (1816), Brasilien Bibliothek der Robert Bosch G mebtt, Sttutgart 
Muitos dos desenhos de aves são de exemplares obviamente taxidermizados, dobrados e comprimidos. Não fazem boa ilustração. Finalmente, alguns exemplares de aves e mamíferos são representados recém-atirados, o que é indicado por delicados sangramentos, que, na realidade, dão um certo encanto perverso.

Todas as pranchas, porém, permitem a pronta identificação das espécies; nesse campo nada ficam a dever às similares européias da época, e confirmam o status normalmente profissional de Alexandre Rodrigues Ferreira.

"Os mammaes": a grande monografia de Alexandre, sobre os mamíferos "dos três rios", Amazonas, Negro e Madeira, foi publicada em 1934 pelo Instituto Geográfico e Histórico da Bahia, de forma pura e seca, como se fosse obra contemporânea, sem um comentário sequer de natureza técnica. Carvalho (1965) publicou um comentário, não só sobre esta monografia, mas sobre toda a informação mastozoológica de Alexandre, inclusive manuscritos e estampas então inéditos da Biblioteca Nacional. Esses comentários cingem-se unicamente às identificações, que aparecem uniformemente boas. É, porém, possível ir um pouco mais a fundo. Da leitura da monografia entende-se bem que Alexandre tinha bom domínio da literatura contemporânea e que encarava os problemas de identificação e de descrição com adequado espírito crítico. Suas descrições são profissionais, dentro do padrão comum da época, concentrando-se em feições morfológicas salientes (número de dígitos, presença ou ausência de barba) e no colorido. São descrições comparáveis às de Etienne Geoffroy, o grande beneficiário das coletas de Alexandre.

Goeldi (1895, 1982), que não gostava de brasileiros, disse que a produção científica de Alexandre é "de pequeno calado científico". Como discutido acima, não concordo com essa avaliação: antes a aplicaria à produção do próprio Goeldi, operoso mas irremediavelmente medíocre.

Não têm tampouco valor nenhum para mim afirmações do tipo de que os bichos de Alexandre acabaram por ter ficado melhor em Paris do que em Lisboa, por terem caído assim nas mãos de cientistas mais preparados e melhor equipados (Pinto, 1979, p. 57). Não tenho dúvida, repito, de que Alexandre teria feito um trabalho pelo menos tão bom quanto o de Saint-Hilaire, levando ainda sobre este a vantagem de ser um homem de bem.

Uma consideração final sobre Alexandre como zoólogo diz respeito à etiquetagem dos exemplares e à catalogação na Ajuda. A primeira metade do século XIX foi o tempo do início do alerta quanto aos registros de procedência dos exemplares de museu. Foram exatamente os grandes zoólogos de campo, Wied, Spix, Natterer, Castelnau, que primeiro compreenderam a natureza e a problemática da distribuição geográfica dos animais, e que primeiro se ocuparam em documentar a procedência dos bichos coletados, etiquetandoos individualmente. Essa preocupação demorou ainda um pouco para atingir os gabinetes dos museus, e catálogos de coleção em ordem só aparecem uma geração mais tarde.

Há, porém, evidência publicada de que Alexandre de alguma maneira etiquetava seu material. Na relação (Pires de Lima, 1953) da oitava e última remessa do Negro, expedida da foz do Madeira em 11 de setembro de 1788, lê-se, a respeito do material enviado em frascos: "Numero das contas que levão os Productos, pelas quaes, se saberão os nomes, que lhes correspondem". Cada frasco tem sua sequiência própria; fica claro que Alexandre não mantinha um catálogo geral, mas se ocupava de cada unidade de remessa (caixão, frasco, etc.) individualmente.

Essa etiquetagem perdeu-se. Há comentários (Pires de Lima, 1953, p. 33; Tavares da Silva, 1947, p. 165) sobre sabotagem na Ajuda, havendo suspeitas, mas não revelações, sobre os eventuais criminosos. Contudo, mesmo que essa informação tivesse sobrevivido, seria de pouca utilidade, pois referia-se apenas ao nome vulgar do bicho e à estação de embarque ("Barcellos", "Rio Negro", etc.).

Essa própria informação, no caso da Ajuda, nem sempre é firme. Há, por exemplo, na coleção atribuída a Alexandre (J. Bethencourt Ferreira, 1923) um exemplar de Caiman latirostris, identificado por Bocage e, portanto, provavelmente certo, que não ocorre em nenhuma região onde Alexandre tenha estado.

Quer-me parecer que, com a descrição dos macacos e com a publicação dos "Mammaes" e das pranchas, encerrou-se um ciclo de apro- 
veitamento dos trabalhos de Alexandre Rodrigues Ferreira. Os exemplares e estampas estão esgotados, e resta apenas a exegese dos textos, até hoje muito mal aproveitados.

\subsubsection{As remessas de Alexandre}

Pires de Lima (1953) publicou diversas listas de remessa de animais enviados por Alexandre a Lisboa. Contêm elas algumas espécies que, a julgar pelos nomes vulgares, não foram incluídas na Viagem Filosófica de 1971. Essas listas ampliam, portanto, a dimensão das coleções de Alexandre. Um único caveat é que os nomes vulgares devem ser interpretados. Isto é, contudo, bem menos difícil do que parece: os nomes de espécies comuns são firmes e têm vida longa, especialmente na Amazônia. No caso de Alexandre é possível ainda verificar sua aplicabilidade na comparação com as figuras da Viagem, facilmente identificáveis. No que segue apresento uma lista das formas ("productos") alistados nas remessas, com a minha interpretação. Esta se baseia primeiramente em experiência pessoal de cerca de cinqüienta anos de coleta na Amazônia; em alguns casos, devidamente anotados, recorri à literatura, seja aos catálogos sistemáticos (Pinto, 1938, 1944; Vieira, 1955), seja a obras lingüísticas (Martius; 1867; Tastevin, 1923a-c).

Não usei os nomes vulgares constantes da lista final da Viagem Filosófica (Rodrigues Ferreira, 1971) porque certamente são devidos a quem identificou as estampas, não a Alexandre; ele dificilmente usaria o nome vulgar "mabuia" (p.160). Também contém essa lista erros que Alexandre não cometeria: por exemplo, chamar de "curimbatá" uma espécie de Curimatus, à qual se aplica no Brasil inteiro o nome "saguiru", sendo curimbatá universal para o gênero Prochilodus.

\section{Peixes}

Acará: os peixes pequenos da família Cichlidae; em geral com um qualificativo (por exemplo, acará-doido).

Acari: os cascudos da família Loricariidae.

Anujá: os bagres da família Trachycoristidae.
Arauanã: Osteoglossum bicirrhosum, família Osteoglossidae; também aruanã.

Curumará: Lepidosiren paradoxa, família Lepidosirenidae (Martius, 1867, p. 447)

Jeraqui: Prochilodus brama, família Prochilodontidae; hoje jaraqui.

Jundihá: bagres pequenos e médios da família Pimelodidae, especialmente do gênero Rhamdia; também jandiá.

Mandué: bagres da família Ageneiosidae; mais freqüentemente mandubé.

Mussi (= Mussum): Synbranchus marmoratus, família Synbranchidae.

Pirá-catimbau: Tastevin (1923c, p. 726) em sua clássica monografia sobre o tupi da Amazônia, incluindo nomes de bichos e plantas, oferece a variante pirá-caximbu; os dicionários modernos de fato dão que caximbu é um cachimbo usado no catimbó. Pensa-se, portanto, em acari-cachimbo, nome aplicado a diversas espécies de cascudos (Loricariidae) de cabeça comprida e afilada; entre as pranchas da Viagem háa figura de uma Farlowella, um dos acaris-cachimbo.

Pirá-manha: "Manha" (mãe) é o protetor sobrenatural de cada animal (Tastevin, 1923b, p. 628). "Pirá”é peixe. Mais não pude averiguar.

Puraquê: Electrophorus electricus, peixe elétrico, família Electrophoridae.

Surubim: os bagres grandes da família Pimelodidae, subfamília Sorubiminae.

Tarayraboya (erroneamente alistada como serpente): Lepidosiren paradoxa, família Lepidosirenidae; dita também trairambóia, mais conhecida hoje como pirambóia.

Tareyra: peixes do gênero Hoplias, família Erythrinidae (traíra).

Tucunaré: espécies grandes do gênero Cichla, família Cichlidae.

Uacary: o mesmo que acari.

Uacary pucu: cascudo não identificado; "pucu" quer dizer comprido (Tastevin, 1923b, p. 655; Martius, 1867, p. 85). Poderia ser uma das espécies grandes de Loricariidae, por exemplo do gênero Pterygoplichthys.

Yacundá piranga: "yacundá” (= jacundá) aplica-se às espécies de Crenicichla (família Cichlidae); "piranga" quer dizer "vermelho encarnado" (Tastevin, 1923b, p. 653); não identifiquei a espécie. 
Anfíbios

Aru: Pipa pipa, família Pipidae.

Boya assica (erroneamente alistada como serpente) $=$ boiacica, nome dado na Amazônia às espécies de gimnofionos, especialmente do gênero Siphonops.

Cururu: sapos do gênero Bufo, especialmente na Amazônia Bufo marinus, família Bufonidae.

Cutaca: qualquer anuro pequeno; o equivalente de perereca.

\section{Répteis: Testudines}

Cabeçudo: Peltocephalus dumerilianus, família Pelomedusidae.

Jabutim: quelônios do gênero Geochelone, família Testudinidae; na Amazônia ocorrem G. denticulata e G. carbonaria; a pronúncia corrente é jaboti.

Jabutim juruparigê: Platemys platycephala (Mittermeier, Medem \& Rhodin, 1980).

Jabutim muritinga: não identificado. Martius (1867, p. 72) diz que "morotinga" é coisa branca.

Matamatá: Chelus fimbriatus, família Chelidae.

Muntaumatá (= matamatá, v.s.): Alexandre dá uma boa diagnose em latim.

Pituí (= pitiú), tartaruga-de-cheiro: Podocnemis sextubercu-lata, família Pelomedusidae.

Tartaruga grande: Podocnemis expansa, família Pelomedusidae.

Uirapequê: Podocnemis erythrocephala, família Pelomedusidae; pronúncia corrente irapuca.

\section{Répteis: Crocodylia}

Jacaretinga: Caiman crocodilus, família Alligatoridae.

\section{Répteis: Sauria}

Jacuraru: na Amazônia, lagartos do gênero Tupinambis, família Teiidae.

\section{Répteis: Serpentes}

Acutiboya: hoje se aplica a Oxybelis aeneus, família Colubridae. Martius (1867, p. 434), contanto, explica: "qui Cutiae insidiatur", aquele que embosca a cotia, o que não se aplica a Oxybelis, que se alimenta de lagartos e de pequenos anfíbios.

Araraboya: Boa canina, família Boidae.

Boya assica: engano; ver Anfíbios.

Boya membeca: não identificada; "boya" é cobra; "membeca" quer dizer, ainda hoje, "mole"; possivelmente um gimnofiono, como boiacica, ou um peixe-ápodo.

Boya pinima: não identificada; "pinima" quer dizer pintada; possivelmente uma cobra-coral (q.v.i.), embora este nome seja explicitamente usado por Alexandre. Martius (1867, p. 440) diz "Boi-pinima, Boya pinima i.e. pictus. Elaps".

Cobra de coral: serpentes das famílias Aniliidae, Colubridae e Elapidae com um padrão mimético de anéis pretos, brancos e vermelhos; numerosas espécies amazônicas.

Cujubi boya: não identificada; cujubi é uma ave (q.v.).

Cururu boya: serpente que come sapocururu (Martius, 1867, p. 447). No sul do Brasil aplicado às vezes a Waglerophis merremii, família Colubridae (mais conhecida por boipeva). Na Amazônia possivelmente se refira a uma espécie de Xenodon ou a Hydrodynastes gigas, todas da família Colubridae.

Giboya: Boa constrictor, família Boidae.

Jararaca: Bothrops atrox, família Viperidae.

Parauá boya: Bothrops bilineatus, família Viperidae; o nome tupi não sobrevive, mas sobrevive sua tradução cobra-papagaia (Martius, 1867, p. 467, "serpens colore variegatus Psittaci”).

Purunupàa-boya: possivelmente a jibóia, Boa constrictor, família Boidae (Tastevin, 1923c, p. 742).

Sacahyboya: diversas serpentes ágeis da família Colubridae, que se diz açoitarem as pessoas ("surradeiras"-já em Tastevin, 1923, passim).

Sucuruju: Eunectes murinus, família Boidae.

Tarayraboya: engano, é um peixe, q.v.

Aves

Acurao: aves das famílias Nyctibiidae e Caprimulgidae; equivalente a bacurau.

Andorinha ou muriny: nome genérico para 
as aves da família Hirundinidae, freqüentemente mal aplicado a outras aves de vôo semelhante.

Antim-antim ou gaivota: Tastevin (1923c, p. 693) tem átianti, gaivota; Martius (1867, p. 439) tem "atyaty, Larus, gaivota dos portugueses". Na Amazônia aplica-se a Phaetusa simplex e Sterna superciliaris, família Laridae.

Anum: gênero Crotophaga, família Cuculidae.

Araçari: tucanos pequenos dos gêneros Pteroglossus e Selenidera, família Ramphastidae.

Arapaçu: designação coletiva dos passarinhos da família Dendrocolaptidae.

Arara: Psittacídeos grandes dos gêneros Anodorhynchus e Ara.

Arara encarnada: Ara macao, família Psittacidae.

Auapé assoca: Jacana jacana, família Jacanidae (Martius, 1867, p. 435, aquapeaçoca).

Caracaraí: Daptrius ater, família Falconidae (Pinto, 1938).

Carará: Anhinga anhinga, família Anhingidae.

Corica (= curica): papagaios pequenos do gênero Amazona, família Psittacidae. O nome quer dizer rouco (Martius, 1867, p. 135, ajurucurica).

Coroca: Crotophaga major, família Cuculidae. Também anu-coroca.

Cujubim: Pipile pipile, família Cracidae.

Galo da serra: Rupicola rupicola, família Cotingidae.

Garça: espécies brancas e cinzentas da família Ardeidae.

Gavião: aves das famílias Accipitridae e Falconidae.

Ierena ou corta-água: família Rynchopidae (Pinto, 1938).

Inambu toró: Tinamus major, família Tinamidae.

Itaã (= itã): alistada como ave; conheço apenas como molusco bivalvo fluvial.

Jacamim: gênero Psophias, família Psophiidae; há na Amazônia três espécies.

Japiim: aves do gênero Cacicus, família Icteridae; há na Amazônia duas espécies.

Macucaua: tinamídeos da mata, principal- mente do gênero Crypturellus, mas também Tinamus.

Maguary: Ardea cocoi, família Ardeidae.

Massarico: designação genérica para a família Charadriidae.

Murucututu: corujas grandes do gênero Pulsatrix, família Strigidae.

Mutum: gênero Crax, família Cracidae; três espécies na Amazônia.

Papagaio corica: ver Corica.

Parauá: papagaios, Psittacidae de tamanho médio.

Parauá-hy: Psittacidae do gênero Pionus (Pinto, 1938, p. 212, tem a leitura errada "paraná-i").

Pavão: termo aplicado a diversas aves vistosas; geralmente acompanhado de um determinativo (por exemplo, pavão-do-pará).

Pequi (= Ipequi): Heliornis fulica, família Heliornithidae.

Periquitos: as espécies de Psittacidae de pequeno tamanho, especialmente do gênero Forpus.

Picaçu: pomba grande, geralmente Columba cayennensis, família Columbidae.

Picapau: designação genérica para as aves da família Picidae e, na Amazônia, também Dendrocolaptidae (pinica-pau).

Piranha-uirá: Tyrannus savanna, família Tyrannidae, tesourinha (tradução literal do nome: "piranha" é tesoura, Tastevin, 1923b, p. 653).

Quiquiá: não identificado.

Sahi: designação aplicada a espécies de pássaros pequenos de cor azul (Tastevin, 1923c, p. 730), especialmente sanhaços, família Thraupidae (Martius, 1867, p. 473, Thraupis sayaca).

Saracura: designação geral das aves paludícolas da família Rallidae.

Sigana (=cigana): Opisthocomus hoatzin, família Opisthocomidae.

Suiriri: Tyrannus melancholicus, família Tyrannidae.

Surucuá: designação coletiva das aves da família Trogonidae.

Suriti (= juriti): Leptotila verreauxi, família Columbidae (na época era freqüente a substituição de $s$ por $j$ ou $x$ : o rio Xeruini já foi Serevini).

Tamburupará: aves do gênero Monasa, 
família Bucconidae. Outras formas: tangurupará, tango-do-pará, todas derivadas (diz Tastevin, 1923c, p. 736) de tunguri-pará.

Tauató: designação de vários gaviões escuros da família Accipitridae.

Tayassu-uirá: Martius (1867, p. 478) diz "Tajasu, Tayaçu-uira (guira) isto é, avis Dicotylis (Rio Branco) - avis Cozzygus: Natterer". Aparentemente seria Coccyzus minor, família Cuculidae, que Natterer coletou no Pará (Pinto, 1938, p. 170). Tastevin (1923c, p. 740) copia Martius, mas ajunta "avepescadora". Esta espécie habita os manguezais e, como os outros anus, ocasionalmente pesca (Sick, 1984, p. 318). O problema é que Alexandre, nesta fase da sua vida, não andou perto de nenhum manguezal. Possivelmente o nome se aplicasse, no interior, a outros cucos.

Tucano: espécies grandes da família Ramphastidae.

Tuiuiu: Jabiru mycteria, família Ciconiidae.

Uanambé (= Anambé): designação aplicada a diversas formas da família Cotingidae, geralmente acompanhada de qualificativo (por exemplo, anambé-roxo).

Uanambu-assu (= nambu guaçu): Crypturellus variegatus, família Tinamidae.

Uarirama-assu: Ceryle torquata, família Alcedinidae, martim-pescador-grande, ariramba-açu.

Uirá membu: Cephalopterus ornatus, família Cotingidae (Pinto, 1944, uiramembi).

Uirá pagé: Piaya cayana, família Cuculidae, alma-de-gato (Pinto, 1944).

Uirá tatá: passarinhos vistosos do gênero Phoenicircus, família Cotingidae (Pinto, 1944).

Uru: aves galiformes do gênero Odontophorus, família Phasianidae; duas espécies na Amazônia.

Urubitinga-y: urubitinga, urubu branco, hoje, na Amazônia a despeito da freqüente atribuição na literatura a gaviões grandes, é o urubu-rei (Sarcoramphus papa), família Catarthidae. Não sei a que viria o sufixo "y", diminutivo.

Urubu: as espécies dos gêneros Coragyps e Catarthes, família Catarthidae.

Yaçaná (= jaçanã): Jacana jacana, família Jacanidae.
Yereua (= jereba): urubu (q.v.s.).

Yriúa: não identificada.

\section{Mamíferos}

Acutypuru: designação coletiva para os roedores da família Sciuridae (esquilos, caxixes, caxinguelês, serelepes).

Acutypuru pardo: diversas espécies de Sciurus de pele avermelhada.

Acutypuru preto: Sciurus do grupo aestuans.

Acuti-yaua-reté: não identificado.

Boto: ocorrem na Amazônia dois cetáceos, Inia geoffrensis, família Platanistidae, botobranco, boto-vermelho ou boto-malhado, e Sotalia fluviatilis, família Delphinidae, botopreto ou tucuxi.

Cayarara: Cebus albifrons, família Cebidae.

Cutynayas: provável corruptela de acutiwaya, cotia-de-rabo, Myoprocta, família Dasyproctidae (Tastevin, 1923b, p. 641).

Irara (macaco): Eira barbara, família Mustelidae. Obviamente não é um macaco, embora até hoje a confusão seja feita.

Japuçá (= Uapuçá): espécies de Callicebus, família Cebidae; na Amazônia ocorrem diversas.

Jurupixuna: espécies do gênero Saimiri (mico-de-cheiro), família Cebidae, várias espécies na Amazônia.

Lontra: Lutra longicaudis, família Mustelidae.

Macaco de boca preta: ver Jurupixuna.

Macaco de prego ou itupuhá: espécies de Cebus (três na Amazônia), família Cebidae.

Macaco Uyapeçá: ver Japuçá.

Maracajá: gatos pintados do gênero Leopardus, família Felidae, desde o pequeno L. tigrinus até a jaguatirica, ou maracajá-açu, L. pardalis.

Mucura: designação coletiva dos marsupiais da família Didelphidae, especialmente do gênero Didelphis; na Amazônia, D. marsupialis.

Mucura-xixi: Philander opossum, família Didelphidae.

Onça pequena: ou jovem de Panthera onca ou adulto de jaguatirica (Leopardus pardalis).

Paca: Agouti paca, família Agoutidae.

Parauacu: macacos do gênero Pithecia, 
família Cebidae.

Peixe-boi: Trichechus inunguis, família Trichechidae.

Preguiça: designação coletiva dos Bradypodidae.

Preguiça de lato ou ahy-sauiá: "ahy" é preguiça; "sauiá" (sawiya) é rato (Tastevin, 1923c, pp. 691 e 732). A palavra "lato" poderá ser um erro de leitura ou de imprensa por "rato". O bicho não é exatamente identificável, com certeza, mas sugere-se um rato-de-espinho, roedor arbóreo do gênero Echimys, família Echimyidae.

Tamanduá: Myrmecophaga tridactyla, família Myrmecophagidae.

Tamanduahy: Cyclopes didactylus, família Myrmecophagidae.

Tatu: designação coletiva da família Dasypodidae (seis espécies na Amazônia).

Yauara-caá-pera: provavelmente a irara ou papa-mel (Eira barbara, Mustelidae), ou seja, o cachorro (yauara) da caipora (caapera) do folclore indígena.

\section{SÉCULO XIX}

Os dois precursores, Marcgrave e Alexandre Rodrigues Ferreira, homens dos séculos XVII e XVIII, têm alto interesse histórico, mas tiveram pouco impacto científico. Este só começou a ser sentido no primeiro quartel do século XIX. A Zoologia fez nessa época, dentro da nossa óptica, rápidos progressos, pela interação de dois mecanismos: aceleração no conhecimento de faunas, levando também a uma conscientização zoogeográfica, e aperfeiçoamento da sistemática, por meio de obras no estilo do Systema Naturae, cobrindo de forma diagnóstica, seja toda a Zoologia, seja uma classe ou ordem.

O progresso no conhecimento de faunas obviamente se dava de duas maneiras. Por um lado, o simples acúmulo de exemplares nos grandes museus possibilitava melhores revisões sistemáticas. Por outro lado, a publicação dos resultados de expedições extensas e demoradas não só fornecia rica matéria-prima para revisões, como facilitava a identificação de materiais, melhorando o acervo dos museus e ampliando o acesso à pesquisa em sistemática.
Estudaremos sob este ponto de vista cinco grandes expedições que se realizaram no Brasil no século XIX: Spix e Martius, Maximilian zu Wied-Neuwied, Johannes Natterer e a missão austríaca, Castelnau e Deville. Mencionaremos ainda duas expedições de pouca importância zoológica, Langsdorff e Agassiz.

\subsection{Spix e Martius}

A expedição de Spix e Martius (para um estudo um pouco mais detalhado, com itinerário, ver Vanzolini, 1981) foi, como dito, em parte uma consequiência da invasão de Portugal pelos exércitos napoleônicos. A mudança da corte portuguesa para o Brasil (trazendo junto um volumoso e ativo corpo diplomático) tornou impossível a política de fechamento do país aos estudiosos do mundo. Por exemplo, Langsdorff, cônsul da Rússia, nesse caráter realizou sua abortada expedição. $\mathrm{O}$ episódio fundamental, porém, foi o casamento do príncipe D. Pedro com a arquiduquesa Leopoldina da Áustria. Não só trouxe ela no seu séquito uma ponderável força-tarefa de pesquisa biológica, como também vieram, de arrasto, os dois inexcedíveis naturalistas bávaros. Spix tinha 36 anos ao começar a viagem em 1817, Martius apenas 23. Viajaram ininterruptamente por trinta meses, seguindo o itinerário mais inteligente que se possa imaginar.

Um aspecto de viagem que não tem merecido atenção, e é difícil atacar com os recursos de biblioteca do Brasil, é que a leitura do livro que relata a viagem (a Reise, Spix e Martius, 1823-36, 1938) indica que Martius havia feito um eficiente estudo de considerável bibliografia, de natureza diversa, que havia na Europa sobre o Brasil.

É necessário também ressaltar, como no caso de Alexandre Rodrigues Ferreira, a concomitância de altos interesses científicos com questões mais mundanas, tais como agropecuária, comércio e, principalmente, mineração. A Reise contém dentro de si um verdadeiro compêndio de economia brasileira no início do século XIX.

Spix e Martius começaram, como todos, pelos arredores do Rio de Janeiro (trecho 


\section{Litografia aquarelada do livro de Johann Baptiste von Spix Simiarum et $V$ espertilionum B rasiliensium species novae.. \\ (M unique, 1823), Biblioteca do IE B - U SP}

muito rico, aliás, da Mata Atlântica), visitando especialmente a Fazenda Mandioca, de Langsdorff, na Serra da Estrela. Em seguida vieram para a província de São Paulo, onde pararam em Ipanema (próximo a Sorocaba), como todos os teutófonos, na fundição de ferro operada por metalúrgicos alemães. Daí seguiram para as minas de ouro e diamantes em Minas Gerais, atravessando a seguir a Bahia e cortando as caatingas para o norte, até Oeiras, então capital do Piauí. Terminaram o trecho em São Luís do Maranhão, de onde seguiram embarcados para Belém, para iniciar uma última fase, de extensa exploração da hiléia, subindo o Amazonas até Tabatinga, o Japurá até Araracoara, na Colômbia, e o Negro até Barcelos.

Esse itinerário deu-lhes a oportunidade de ver quase toda a diversidade ambiental do Brasil: mata atlântica, cerrado, caatinga e hiléia. Deixaram de ver os pinheirais e as pradarias mistas do Rio Grande do Sul; tratando-se, porém, de faixas extratropicais de menor expressão geográfica, essa lacuna não prejudicou a extraordinária sistematização feita por Martius das paisagens maiores do Brasil - sistematização que ainda constitui, na sua inteireza, a base dos conceitos correntes de domínios morfoclimáticos (Ab'Sáber, 1977; Seibert, 1983).

Spix foi o responsável pelos relatórios zoológicos da viagem. Morreu em 1826, debilitado pelas moléstias tropicais contraídas na Amazônia, sem ver a obra completamente publicada: o fiel Martius encarregar-se-ia disso.

\subsubsection{As obras de Spix}

Spix publicou sobre mamíferos: macacos e morcegos (1823), sobre aves (1824a), sobre anfíbios (1824b, 1840a) e, entre os répteis, sobre quelônios (1824b, 1840b), crocodilianos (como lagartos) e lagartos (1825). As serpentes e anfisbenas foram descritas por Johann Wagler (Spix, 1824c) e os peixes por Louis Agassiz (Spix, 1829), com parte das espécies especificamente atribuída a Spix.

Convém neste ponto explicitar os critérios aqui usados para avaliação da contribuição dos viajantes ao progresso da Zoologia brasileira. Como ficou dito, e é obvio, a pri-

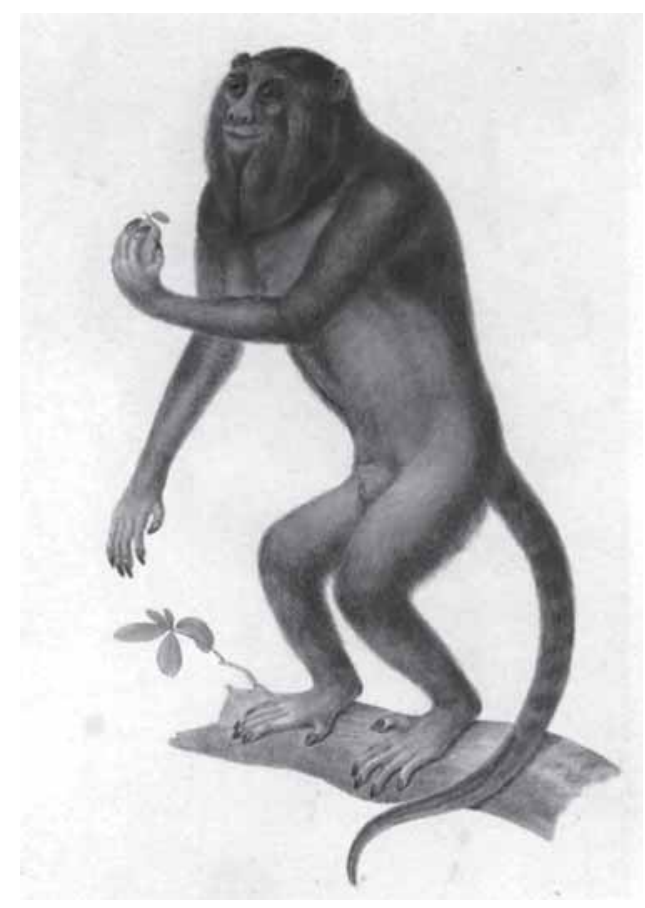

meira importância das expedições pioneiras residia na ampliação do conhecimento das faunas. Não se estranhe, portanto, a insistência em species novae nos títulos dos livros de Spix: é a constatação de uma realidade. Por esse tempo começa a afirmar-se a consciência da inteireza das faunas e de suas relações ecológicas e geográficas, mas Spix neste aspecto ainda pertence à pré-História: o valor de seu trabalho residia, como ainda reside, na boa descrição e ilustração das espécies e no registro das localidades-tipo.

Durante a Segunda Guerra Mundial (193945) Munique foi duramente bombardeada, e as notícias contemporâneas (Lorenz Müller, in litt.) eram de que as coleções estavam em grande parte perdidas. Mais tarde verificouse que a situação era menos grave, e que muitos materiais haviam sobrevivido, em Munique e em outros museus. Notícias detalhadas são dadas na obra em homenagem a Spix editada por Fittkau (1983).

\subsubsection{Mamíferos, Primates}

Os macacos são um dos grupos mais precocemente conhecidos no Brasil: das 62 espécies reconhecidas hoje (Groves, 1993) 33, ou seja, mais de $50 \%$, já eram conhecidas 
quando da publicação do livro de Spix. É fácil de compreender: são animais diurnos, arborícolas, gregários, altamente conspícuos. São visualmente orientados, o que torna fácil seu reconhecimento pelo homem, também um primata visualmente orientado. (É mais difícil a sistemática de animais orientados pelo som, como os anuros, ou por sentidos químicos, como certos peixes.) O tamanho dos exemplares e a boa resistência das peles dos símios facilitam a preparação, ainda mais que os nativos de regiões florestadas costumam ter prática de coureá-los.

Cinco autores apenas eram responsáveis pelas 33 espécies de macacos então conhecidas: Lineu $(1758,1766)$ com 10 espécies; Hoffmansegg (1807), com 3; Etienne Geoffroy Saint-Hilaire (1806, 1809a,b, 1812), com 10, Humboldt (1812) com 8; e Kuhl (1820), com 2 espécies.

De acordo com as Regras Internacionais de Nomenclatura Zoológica, deve fazer parte da descrição de qualquer nova espécie a designação de um exemplar "tipo". O termo é infeliz, pois pode levar a crer que se trata de um exemplar que de alguma maneira "tipifique" a espécie. Não se trata disso: o tipo é um exemplar que ancora o nome da espécie. Qualquer dúvida a qualquer tempo sobre a aplicabilidade de um nome deve ser resolvida por referência ao tipo. Nos casos em que, no passado, a designação tenha sido omitida, há mecanismos para designação supletiva. Os tipos são especialmente importantes no caso de espécies antigas, sumária ou insuficientemente descritas, ou sem localidade explícita.

Kraft (1983) reviu os tipos restantes de macacos de Spix; infelizmente, baseou-se fundamentalmente, para atualização da taxonomia, na lista de Cabrera (1958), que é especialmente insegura no que diz respeito a subespécies de mamíferos tropicais, assunto de que Cabrera não tinha experiência pessoal. Revisando o material à luz de literatura recente (especialmente Groves, 1993), podemos dizer que Spix descreveu como novas 28 espécies de macacos; citou 7 como de descrição alheia, mas coletadas e reconhecidas por ele. Das 28 espécies descritas como novas, 8 são hoje válidas e 20 consideradas sinôni- mos. Não se pode atribuir esse alto número de sinônimos a desconhecimento da literatura: as obras relevantes eram de amplo conhecimento geral e os cientistas mantinham boas relações pessoais. A elevada sinonímia deve ser antes atribuída a dificuldades intrínsecas dos grupos (variação sexual, ontogenética e residual da coloração da pelagem) e à falta de ilustrações nas descrições originais. Relativamente ao problema da variabilidade das formas, Spix descreveu sob 4 nomes diferentes a espécie Cebus apella (L., 1758) e sob dois nomes Cebus albifrons (Humboldt, 1812). Até hoje, porém, não existe nenhuma revisão suficiente de Cebus, gênero sobre o qual não há consenso (Groves, 1993). Adicionalmente, Spix descreveu Lagothrix lagothricha (Humboldt, 1812) como duas espécies novas, bem como Pithecia monacha e Callicebus personatus (E. Geoffroy, 1812). Callicebus e Pithecia são gêneros difíceis até hoje; Lagothrix nem tanto.

Pode-se resumir a contribuição de Spix à primatologia neotropical dizendo-se que ajuntou 8 espécies às 33 então conhecidas, o que contribuiu sensivelmente, pela qualidade de suas descrições e ilustrações, para a melhoria do nível da pesquisa.

\subsubsection{Mamíferos, Chiroptera}

Os morcegos constituíam um grupo difícil para o zoólogo do início do século XIX. São animais voadores de vida noturna, difíceis de capturar antes do aparecimento das mist nets: das 15 espécies coletadas por Spix, 6 foram obtidas dentro de habitações humanas. A taxidermia deforma bastante partes moles dos morcegos importantes para a sistemática, tais como o focinho e as orelhas. Os exemplares taxidermizados são frágeis e sofrem na coleção (Lawrence e Genett, 1988). Acresce que é um dos grupos em que os caracteres externos e a fisionomia são menos úteis à identificação, os melhores caracteres residindo no crânio e, principalmente, na dentição - isso apenas começava a ser percebido no tempo de Spix.

Sob outro ponto de vista, muitas espécies de morcegos têm vagilidade extrema, migrando por longas distâncias (Eptesicus) ou ocu- 
pando territórios muito grandes (Myotis). Estes fatos levam o zoólogo a erros, decorrentes de óptica regional: julga serem novas espécies já anteriormente descritas de outras áreas, às vezes remotas. Na realidade, a sistemática dos morcegos neotropicais ainda está longe da saturação, ocorrendo a todo instante descrição de espécies novas e reajustes da sistemática, tanto no nível específico quanto no genérico.

Segundo Koopman (1993), ocorrem no Brasil cerca de 120 espécies de quirópteros: 28 já eram conhecidas ao tempo de Spix, que descreveu como novas 9 , das quais subsistem 5: Tonatia bidens, Trachops cirrhosus, Diphylla ecaudata, Thyroptera tricolor e Promops nasutus. A revisão dos tipos de Spix por Kraft (1983) nada ajunta ao dito acima.

Além das dificuldades inerentes ao grupo, deve-se ainda relevar que a literatura sobre morcegos era muito dispersa: as 28 espécies haviam sido descritas em 15 trabalhos, de variada natureza, por 11 autores. O único a descrever mais que Spix foi Etienne Geoffroy de Saint-Hilaire, que descreveu 10 espécies em 4 trabalhos.

\subsubsection{Aves}

A sistemática tradicional de aves difere da de todos os demais grupos de vertebrados (menos talvez da dos anfíbios) pela falta de caracteres objetivos. É baseada em peles sem ossos, e os caracteres importantes não são enumeráveis ou (com exceção de algum raro bico ou tarso) mensuráveis. Os gêneros são definidos por consenso - na realidade é uma curiosidade para os zoólogos em geral o consenso que existe na Ornitologia. Há poucos estudos da estrutura geográfica das assim chamadas subespécies reconhecidas: há que aceitá-las na base da confiança.

Estabelecidos estes caveats, podemos dizer, grosseiramente, que ao tempo de Spix cerca de $30 \%$ eram conhecidos das aproximadamente 2.400 formas de aves aceitas hoje para o Brasil. Haviam escrito, antes de Spix, autores de amplo compasso: além de Lineu, houve Vieillot, Gmelin, Temminck, Boddaert, P. S. Müller, Latham e alguns outros de menor volume. No que segue baseio-me no artigo de
Hellmayr (1906) sobre os tipos de Spix, atualizado na medida do possível. A revisão dos tipos spixianos por Reichholf (1983) e a lacônica avaliação publicada na mesma obra por Sick (1983) pouco ajuntam à história que se pode colher da literatura geral, começando com a primeira revisão (Hellmayr, 1906) dos tipos.

Spix ilustrou e descreveu 326 espécies de aves, uma das mais ponderáveis contribuições de qualquer tempo. Oitenta e nove formas eram anotadas como não sendo suas; às vezes a atribuição é explícita, às vezes precisamos recorrer a Hellmayr (1906). Das 237 formas descritas como novas, temos informação segura sobre 220, das quais 67 (30\%) são hoje consideradas válidas e $153(70 \%)$ caíram na sinonímia (Sick, 1983). É uma excelente porcentagem para a época; o valor da contribuição é realçado pela qualidade da ilustração.

\subsubsection{Répteis e anfíbios}

Houve um problema inicial com a coleção de Spix ao regressar à Europa (Vanzolini, 1981): insinuaram-se nela três espécies européias de serpentes, uma de anfisbenídeo e uma de tartaruga. Todas foram descritas como brasileiras e como novas, a tartaruga por Spix, as cobras e o anfisbenídeo por Wagler (uma delas duas vezes). Das 35 espécies de serpentes brasileiras realmente presentes, cinco eram de outros autores, uma com proposta de nome novo. Das 34 espécies descritas por Wagler como novas 16 eram válidas, 4 eram as formas européias já mencionadas, 12 são consideradas sinônimos e sobre 2 há dúvidas. Ainda misturado com as serpentes havia um gimnofiono, uma espécie de Mikan (q.v.i.), não explicitamente citada mas reconhecível.

Trinta e oito espécies de lagartos são alistadas por Spix, sendo 3 declaradamente de outros autores. Das 35 que ele se atribui 11 são válidas (2 descritas 2 vezes cada) e as demais sinônimas. Spix na realidade descreveu 7 espécies duas vezes consecutivas, 1 espécie três vezes e uma espécie cinco vezes.

Dos 4 jacarés listados apenas um é válido: exatamente ojacaré-açu, Melanosuchus niger.

Quanto aos sapos, 53 espécies estão alistadas, das quais 20 são realmente novas; as 
ilustrações são de qualidade regular. Aqui também Spix descreveu algumas formas mais de uma vez como novas: duas vezes (três casos), quatro vezes (dois casos) e cinco vezes (um caso).

De um modo geral, pode-se dizer que a contribuição herpetológica de Spix e Wagler, embora incluindo algumas espécies importantes, é de qualidade apenas mediana. Militam muito contra o não terem reconhecido espécies européias comuns e as múltiplas descrições sinônimas de formas muito características: Iguana iguana recebeu cinco nomes, Bufo marinus recebeu quatro. O que realmente restou do seu trabalho foram as espécies protegidas pela novidade da fauna.

Os tipos remanescentes foram estudados por Hoogmoed e Gruber (1983). Mais uma vez lembro que as poucas novidades que resultam da revisão dos tipos de Spix testemunham a boa qualidade de suas descrições; os necessários ajustes foram sendo feitos a seu tempo, sem necessidade de recurso aos tipos.

\subsubsection{Peixes}

Como dito, as espécies novas de peixes são atribuídas explicitamente a Agassiz ou a Spix - 54 e 21 espécies respectivamente. Agassiz é responsável por 34 das 36 espécies marinhas - a primeira contribuição ao campo no Brasil - infelizmente sem dados de distribuição geográfica. Das espécies de água doce, Spix descreveu 19 e Agassiz 20. Dez espécies são de outros autores, mais ou menos claramente citados, e sobre 8 não consegui informação suficiente.

Terofal (1983) dá uma lista das espécies descritas por Spix e Agassiz, com as atribuições correntes. É uma lista útil, mas nada adiciona aos catálogos de Fowler (1941, 1948-54).

Seria de esperar que o número de espécies válidas fosse relativamente maior para água doce que para o mar, dadas as possibilidades de endemismos em bacias diversas. As espécies marinhas, ao contrário, e especialmente as pelágicas, têm no geral ampla distribuição, com a decorrente maior probabilidade de já haverem sido descritas de outras paragens. Isso no entanto não se dá:

\begin{tabular}{|lccc|}
\hline \multicolumn{3}{|c}{ Água doce } & Marinha \\
\hline Válidas & 25 & 21 & 46 \\
\hline Sinônimas & 14 & 15 & 29 \\
\hline & 39 & 36 & 75 \\
\hline
\end{tabular}

O valor de $\chi^{2}$ para esta tabela é .0758 , obviamente não significante: não há associação entre o ambiente das espécies e a proporção de validez.

A contribuição de Spix e Agassiz à ictiologia mundial e brasileira não é fácil ao leigo de julgar; os especialistas, contudo, consideram-na muito importante.

\subsubsection{Invertebrados}

A citada obra editada por Fittkau (1983) contém diversos interessantes capítulos sobre as coleções de invertebrados feitas por Spix e Martius. Seu interesse para mim reside principalmente no fato de demonstrarem que a simples disponibilidade de materiais não é suficiente para o progresso da pesquisa. É indispensável um certo grau de maturidade: a despeito das coleções reunidas, nada foi feito na época com respeito aos invertebrados que se compare ao estudo dos vertebrados.

Há uma interessante característica da obra de Spix, que concorre com o dito na introdução deste trabalho, ou seja, que nenhum dos viajantes trouxe contribuição conceitual ou metodológica à Zoologia. Spix pertencia (Stresemann, 1951, p. 176; 1975, p. 175) à escola idealista germânica da Naturphilosophie. Publicou trabalhos dentro dessa orientação, nenhum, porém, relacionado com a viagem ao Brasil: o trabalho de campo modera as fantasias do homem inteligente.

\subsection{Maximilian, Príncipe de Wied-Neuwied}

Maximilian Alexander Phillip, Prinz zu Wied-Neuwied (Prinz Max para os colegas zoólogos), foi um nobre da Renânia que, aos 32 anos de idade, terminadas as guerras napoleônicas, trocou a carreira das armas pela 
vida científica. Influenciado por Humboldt, como tantos outros, decidiu empreender uma expedição ao Brasil, recém-aberto a pesquisadores estrangeiros.

A expedição durou de 1815 a 1817. Saindo do Rio de Janeiro, subiu ao longo da costa até Ilhéus, onde cortou para o interior, na direção de Vitória da Conquista, voltando ao Rio através do estado de Minas Gerais. Entre o Rio de Janeiro e Vitória no Espírito Santo contou com a colaboração de Georg Wilhelm Freyreiss e Friedrich Sellow, coletores profissionais a soldo de vários museus da Europa, principalmente do de Berlim (Papavero, 1971, p. 58).

Wied coletou vertebrados terrestres e publicou sobre eles. Teve a particularidade de publicar muitas espécies novas no livro que escreveu sobre a viagem (Reise, 182021). Não se trata de descrições formais, porém de diagnoses curtas (nenhuma espécie, porém, é duvidosa), enriquecidas pelo contexto geográfico e ecológico. Entre a publicação da Reise (1820-21) e os subseqüentes trabalhos de Wied decorreram alguns anos, durante os quais outros autores, combinados (v.i.) ou não com Wied, publicaram diversas espécies do príncipe como novas. Assim, "salvaram-se" aquelas descritas na Reise, "perderam-se" as das Beitraege (q.v.i.).

Publicou também Wied (por exemplo, 1820) alguns artigos nas revistas científicas do tempo. A massa estruturada das observações, porém, foi publicada de 1825 a 1833 em um livro de quatro volumes, Beitraege zur Naturgeschichte Brasiliens, uma das mais ricas e mais agradáveis obras zoológicas jamais escritas sobre a América do Sul. O livro foi publicado parceladamente e acompanhado por uma série autônoma de estampas (182231), "Abbildungen zur Naturgeschichte Brasiliens", algumas das quais contêm a descrição de espécies novas. Essas estampas constituem um certo problema bibliográfico: não são numeradas nem datadas. Sua seqüência só pode ser restabelecida acompanhando as notícias e recensões da imprensa científica contemporânea, especialmente a revista publicada em Jena por Lorenz Oken, a famosa Isis von Oken. Algumas das pranchas de Wied, como dito, são acompanhadas por um texto, de desenvolvimento vário, às vezes contendo informações relevantes. Como se vê, a bibliografia de Wied não é simples. O presente artigo funda-se nas Beitraege, a obra de síntese.

Abramos um parêntese para dizer que essa viagem ao Brasil, o sonho dourado do Wied militar, matou nele o zoólogo. Sua convivência com os índios do Espírito Santo e Bahia acendeu uma insopitável paixão antropológica. Assim que terminou a publicação dos resultados brasileiros, embarcou para os Estados Unidos, onde realizou, de 1832 a 1834, uma longa e justamente famosa expedição de cunho puramente etnográfico. Não voltou às regiões tropicais e não voltou à zoologia.

Wied morreu aos 85 anos, em 1867, aparentemente lúcido e ao corrente do movimento científico: pouco antes de morrer, provavelmente prevendo que os materiais seriam vendidos após a morte, preparou listas (com a sistemática atualizada) de suas coleções, que mantinha no castelo da família. Eu trabalhei com o catálogo dos répteis: a letra é firme e legível, e não se encontram erros.

Quero começar a apreciação da influência do príncipe por um aspecto de ordem geral, usualmente negligenciado. Ele foi um pioneiro da zoogeografia ecológica no âmbito intracontinental. A Mata Atlântica estende-se da Paraíba (cerca de $07^{\circ} 30^{\prime} S$ ) ao norte do Rio Grande do Sul (cerca de 30³0'S): aproximadamente 2.500 quilômetros, 23 graus de latitude. É óbvio que a temperatura deve ser o fator predominante na distribuição das espécies animais, uma vez que a precipitação é uniformemente alta (é o que permite que exista mata atlântica). Nas Beitraege Wied ocupa-se freqüentemente dos limites latitudinais das espécies. Diz, por exemplo (1825, p. 118) que a iguana não ultrapassa o paralelo de $14^{\circ} \mathrm{S}$, e que Enyalius catenatus (p. 136), outro lagarto, é limitado pelo paralelo de $16^{\circ} \mathrm{S}$. Não quero dizer que ele tenha estudado sistematicamente as distribuições, ou que tenha resolvido alguma questão corológica maior. Apenas que demonstrou clara consciência de uma problemática nova para o tempo, cuja apreensão tinha que ser muito dificultada pelo seu sistema de trabalho, viajando para a frente e pegando poucos bichos. 
Antes de analisar numericamente a contribuição de Wied à faunística do Brasil, fazse necessária uma pequena digressão. Não sei se o fato é conhecido fora da esfera profissional, mas as todo-poderosas "regras de nomenclatura zoológica", publicadas pela International Commission on Zoological Nomenclature (última edição 1985), não têm conteúdo intelectual nenhum. Muitas vezes a sua aplicação agride o senso estético e o próprio bom senso dos pesquisadores sujeitos a elas. São, porém, indispensáveis à boa ordem da casa zoológica. É por isso que são universalmente adotadas, com resmungos e reclamações (como estes), mas sem nunca ter havido cisma ou dissidência. Ao contrário, numerosos zoólogos escrevem, sobre e em torno delas, trabalhos que talvez até julguem ser de pesquisa.

Um dos pilares básicos das "regras" é o princípio de prioridade, que diz que, exceptis excipiendis, o único nome válido de toda e qualquer forma animal é o mais antigo nome legalmente aceitável, proposto após $1^{\circ}$ de janeiro de 1758 , data convencionada de publicação do Systema Naturae. Nomes são de fato essenciais à comunicação; sua estabilidade é fundamental, e toda a ênfase da nomenclatura (como o nome indica) recai sobre nomes, não sobre conceitos.

O princípio de prioridade estabeleceu-se em 1842, em um primeiro conjunto de regras de nomenclatura proposto pelo ornitólogo inglês Hugh E. Strickland e adotado inicialmente na Inglaterra. Foi o germe das presentes "regras" (Stresemann, 1951, p. 266; 1975, p. 263). Até essa época não havia consenso, e cada um agia de acordo com sua própria cabeça.

A cabeça do príncipe era caracteristicamente liberal e generosa. Comunicava-se abertamente com colegas, trocava informações e exemplares - e cada um publicava livremente. Este último detalhe resultou em alguma confusão. Por exemplo, Wied certa vez mandou a seu amigo, o ilustre Blasius Merrem, de Marburg, que Wied muito respeitava na sistemática acima do nível de espécie, um exemplar da cobra-coral venenosa da Mata Atlântica, sem dúvida chamando sua atenção sobre tratar-se de uma espécie nova e das mais lindas. Merrem concordou, e ambos concordaram ainda que, desde que se tratava de uma cobra-coral, o nome corallinus caberia muito bem. Os dois publicaram: a mesma espécie, com o mesmo nome, baseado no mesmo exemplar, e quase na mesma data(Roze, 1966). Um sinônimo-homônimo! Os amantes da nomenclatura vibram com esses casos; as pessoas sensatas aplicam com naturalidade o princípio de prioridade (Merrem publicou um pouco antes e a espécie é atribuída a ele) e não se impressionam demais com a autoria nomenclatural. Todos conhecem a história, todos sabem que o conceito original é de Wied, que foi ele quem coletou o tipo e reconheceu, no campo, a nova espécie. Aliás, todos os pesquisadores da época, despreocupados de formalismos legalistas, atribuíam a espécie a Wied. $\mathrm{Na}$ realidade, sobre ela, dadas as particularidades, não poderia haver dúvida alguma a não ser quanto à prioridade.

Quando, no começo deste século, desencadeou-se na nomenclatura um forte movimento legalista - em parte por ser realmente necessário, em parte pela muleta psicológica que representa para os praticantes - todos esses velhos casos foram resolvidos pela Comissão Internacional de Nomenclatura Zoológica, que publicou, com abundância, suas decisões. Os nomes foram atribuídos estritamente de acordo com as "regras", lastimando-se mas nada se fazendo em casos como o da cobra-coral.

Dessa exata maneira "perdeu” Wied inúmeras espécies novas, que havia comunicado a amigos que estavam preparando obras de caráter geral, nas quais ele achava que as novidades deveriam ser incluídas. Pelos acasos das datas de publicação perdeu ele espécies para Merrem, para Schinz e para Temminck - espécies que ele mesmo depois publicou como novas. Não eram novas, embora sem dúvida fossem dele, uma distinção que, já foi dito, no tempo não existia. Essas sinonímias não representam incompetência de Wied, apenas ângulos especiais de um momento histórico. Por isso, no que segue, pensando na influência de Wied, não prestarei atenção à autoria formal das espécies, mas, apenas, à prioridade na obtenção das cole- 
ções e no reconhecimento das formas: à parte conceitual de preferência à formal.

Considero uma vergonha que até hoje não se haja feito no Brasil um estudo estruturado da obra zoológica de Wied. Biografias não faltam (Ratzel, 1885 - a melhor; Amaral, 1931; Baldus, 1941; Karl Viktor Prinz zu Wied, 1954; Schaden, 1955; Rocha, 1971; Hartmann, 1975; Cascudo, 1977). Quanto à zoologia, porém, há apenas três trabalhos: as revisões dos tipos de aves, por Allen (1889), dos tipos de mamíferos, por Avila-Pires (1965) e dos tipos de répteis e anfíbios, por Vanzolini e Myers (em publicação). As espécies descritas na Reise, especialmente as de aves, foram identificadas e brevemente comentadas por Pinto na edição brasileira (1940) da obra. Uma boa análise das Beitraege, com sua imensa riqueza, porém, ainda é devida. Para este artigo tive que usar ampla e dispersa literatura e, na realidade, não me satisfiz.

O itinerário de Wied foi analisado por Bokermann (1957). As lacunas desse trabalho foram na maior parte supridas por Vanzolini (1992).

Wied passou algum tempo nas caatingas da Bahia e nos "campos gerais" (cerrados) de Minas Gerais, mas a maior parte de sua atividade desenvolveu-se na Mata Atlântica, e esta deve preponderar na avaliação do seu impacto científico.

\subsubsection{Mamíferos}

Na área da Mata Atlântica onde Wied coletou ocorrem cerca de 110 espécies de mamíferos. A sistemática de quase todos os grupos é firme, restando dúvidas (poucas) quanto a morcegos e (muitas) quanto a ratos-do-mato (família Muridae, subfamília Sigmodontinae). Excetuando os ratos (de que Wied descreveu uma espécie importante, Wiedomys pyrrhorhinus) são relevantes cerca de 80 espécies, das quais ele descreveu 58, o que mostra a qualidade do seu trabalho faunístico; devese lembrar que o único instrumento de coleta era a espingarda de carregar pela boca. Das 27 espécies cujo primeiro conhecimento Wied atribui a si mesmo, 18 são válidas: 9 são atribuídas formalmente a ele, 6 foram "perdidas" como comentado acima, e 3 receberam dele nomes pré-ocupados. (Como a correspondência entre nome e espécie, de acordo com as "regras", deve ser biunívoca, ou seja, um e um só nome para cada espécie, um nome utilizado inadvertidamente pela segunda vez no mesmo gênero, dito "homônimo", deve ser automaticamente substituído, a autoria da espécie passando para o autor da substituição: é outra maneira de "perder" uma espécie.)

Nove formas descritas por Wied como novas eram sinônimos "puros", isto é, ele não tinha conhecimento de que tivessem sido anteriormente descritas e nomeadas, ou cometeu enganos de julgamento sobre o valor de diferenças percebidas. Como de costume, Cebus apella aparece 4 vezes; outras 3 espécies aparecem com 2 sinônimos cada; são casos (Callicebus personatus e Nasua nasua) que só foram resolvidos recentemente. Resta como engano puro o caso de 2 nomes para Noctilio leporinus.

\subsubsection{A ves}

Vimos que Wied foi bom mastozoólogo; veremos abaixo que se deu bem na Herpetologia. Seu melhor campo de trabalho foi, porém, a Ornitologia.

Joel Asaph Allen (1889), na sua revisão dos tipos de aves de Wied, conservados desde 1870 no American Museum of Natural History, em Nova York, diz:

\begin{abstract}
"Maximilian, for the time in which he lived and worked, was an excellent ornithologist, combining ample field experience with a good technical knowledge of his subject. He not only took careful measurements, and notes of the color of the eyes, bill and feet, etc., from the freshly-killed bird, but his published descriptions, in respect to minuteness of detail and the careful discrimination of nice points, are not excelled, and rarely equaled, in our best modern works".
\end{abstract}

Os volumes de aves das Beitraege constituem um dos mais completos e equilibrados levantamentos faunísticos jamais feitos. O nível técnico é superior; além dos aspectos citados por Allen, que são pontos relevantes 
para a Sistemática, há uma riqueza de observações em outros campos. Sobre a biologia das espécies são citados dados de reprodução, conteúdo estomacal, canto (expresso no pentagrama), etc. Não se trata de achados ocasionais, mas de uma filosofia de trabalho: por exemplo, Wied às vezes lamenta não ter encontrado o ninho de uma determinada espécie, apesar de tê-lo buscado. A única coisa de caráter esporádico são notas anatômicas, obviamente eventuais. Analisaremos portanto também a contribuição de Wied preferencialmente sob o ponto de vista da faunística.

A sistemática de aves ainda está em evolução no âmbito de família e gênero. Adotei para este estudo um esquema relativamente conservador, que me permite usar sem grandes traumatismos os catálogos de Pinto (1938, 1944, 1978) e de Schauensee (1966). Ocupome apenas das aves continentais, excluindo as marinhas (sem significado regional), das quais Wied tratou 14 espécies.

Dentro desse esquema, ocorrem na região trabalhada por ele 65 famílias de aves. Dessas deixou de coletar representantes de 4: Colymbidae, Oxyruncidae, Cyclarhidae e Compsothlypidae.

As 61 famílias coletadas por Wied variam em número de espécies presentes na região, desde muitas famílias com apenas uma espécie, até Tyrannidae com 59. Fizumaregressão, tomando como variável independente $(x)$ o número de espécies de cada família, e como variável dependente $(y)$ o número de espécies daquela família coletadas por Wied. Se a amostragem fosse perfeita, cada $y$ seria igual ao correspondente $x$, e teríamos uma linha reta passando pela origem ( $a$ da equação da reta, $y^{\prime}=\mathrm{a}+\mathrm{bx}$, igual a zero), com coeficiente de regressão $b$ igual a 1 e coeficiente de determinação, $r^{2}$, também igual a 1 . Obtive uma reta, passando pela origem $(\mathrm{a}=$ $.754+$ ou -.888 ), mas com coeficiente de regressão $(b=.589+$ ou -.0263$)$ significantemente menor que 1.0. O coeficiente de determinação, $\mathrm{r}^{2}=.8948$, é muito bom. Como se vê pelo gráfico, duas famílias de bom porte numérico tiveram representação completa, Accipitridae (21 espécies) e Psittacidae (19 espécies). Uma família, Trochilidae, mostrou o maior déficit (12 sobre 35).

Esses dados estão de acordo com as expec- tativas. O coeficiente de regressão menor que 1 indica que, quanto mais espécies contenha a família, menor a probabilidade de ser completamente representada, o que é intuitivo. As famílias de melhor amostragem (Accipitridae e Psittacidae) são representadas por aves conspícuas, grandes e bem conhecidas dos caçadores regionais. Os beija-flores são na realidade difíceis de coletar, especialmente com espingarda de carregar pela boca.

Passando ao nível de espécie, Wied descreveu nas Beitraege 444, das quais 63 (14\%) das caatingas e campos da Bahia e de Minas. Incluiu portanto 381 espécies da Mata Atlântica. O número máximo aproximado para a área seria de 500: ele obteve mais que 3/4 da fauna regional - um resultado excelente.

Na Reise e nas Beitraege são propostas como novas 125 espécies, quase um terço do total estudado. Dessas mantêm-se como válidas 58; 59 são sinônimos claros; 8 não são identificáveis, principalmente por se terem perdido os tipos (Allen, 1889).

Finalmente, consideremos o aspecto das sinonímias múltiplas, ou seja, o insucesso no reconhecimento de espécies, com a conseqüente atribuição de mais de um nome a cada uma. Este é um indicador seguro da competência do zoólogo, embora a competência de um mesmo indivíduo possa variar de grupo para grupo. Já tivemos ocasião de ver, por exemplo, quanto se iludiram os zoólogos, de todos os tempos, com a variação de pelagem do macaco-prego, Cebus apella. No caso de Wied, pode-se aprofundar um pouco mais a análise, com base nos dados de Allen (1889) sobre os tipos sobreviventes.

Sete vezes descreveu Wied a mesma espécie de ave sob 2 nomes, nenhuma sob 3 ou mais. Em 3 dos 7 casos foi traído por fases de plumagem ou por mudanças ontogenéticas; em 1 caso tratava-se de um albino; em 1 caso o problema era de dimorfismo sexual. Engano puro e simples ocorreu em 2 casos. Sobre 444 espécies, uma performance admirável: o que se chama "um sistemata nato".

\subsubsection{Répteis}

Ocorrem quatro espécies de tartarugas marinhas nas costas do Brasil. Wied alista as 
quatro, mas comete um engano: sua Chelonia mydas é Caretta caretta, como se pode ver na descrição de uma bela gravura na Reise (Wied de roupa social e cartola, olhando a tartaruga desovar) e pelo fato de que $C$. mydas não desova no Brasil. As outras três espécies estão corretas.

Quanto aos cágados (Chelidae) Wied incluiu Emys depressa (Merrem) = Phrynops geoffroanus (Schweigger) e Emys radiolata (Mikan) (Acanthochelys). Faltou-lhe apenas uma espécie, Phrynops tuberculatus. Descreveuum dos jabotis, Geochelone denticulata(L.).

O jacaré, claramente Caiman latirostris (Daudin), está mal identificado como Crocodilus sclerops $=$ Caiman crocodilus (L.).

No que segue não farei comparações numéricas, pois a Mata Atlântica é avara de seus répteis e uma viagem como a de Wied, sempre para a frente, não permite boas amostragens.

A contribuição ao estudo dos lagartos é fraca. Inclui 16 nomes, representando um máximo de 14 espécies. Hemidactylus mabouia é descrito duas vezes (Gekko incanescens e Gekko armatus); na discussão Wied mostra ter-se convencido da individualidade das formas, iludido pela variação do padrão de colorido. O macho (Anolis gracilis) e a fêmea (A. viridis) de A. punctatus são descritos como espécies diferentes. O Cnemidophorus incluído (Teius cyanomelas) não é reconhecível, nem as duas espécies (se forem) de Mabuya, alistadas como Scincus sloanei S. striatus, ambas de Daudin. Como Gymnophthalmus quadrilineatus é apresentada a espécie mais tarde descrita como Micrablepharus maximiliani (Reinhardt \& Luetken). Polychrus marmoratus (L.), Enyalius pictus (Wied), Enyalius catenatus (Wied), Tropidurus torquatus (Wied), Tupinambisteguixin(L.), Ameiva ameiva(L.) e Kentropyx striata (Daudin) são apresentados, às vezes sob outros nomes, mas reconhecíveis.

Dois anfisbenídeos são incluídos entre as serpentes: Amphisbaena punctata $($ Wied $)=$ Leposternon microcephalum (Wagler) e $A$. flavescens $=$ A. alba (L.).

De nível muito superior é a contribuição ofiológica. Seis espécies de outros autores são descritas e imediatamente reconhecíveis: Boa constrictor (L.), Boa cenchria (L.) (Epicrates), Boa aquatica $(\mathrm{L})=$. Eunectes murinus (L.), Coluber nattereri (Mikan) (Thamnodynastes), Dipsas cenchoa (L.) (Imantodes), Crotalus horridus (Daudin) (engano por $C$. durissus ssp. - engano aliás natural para a época). A serpente descrita como Scytale coronata (Merrem) estava mal identificada e foi descrita mais tarde como Pseudoboa neuwiedii (Duméril, Bibron e Duméril). (Era, e ainda é costume, quando corrigindo um colega, homenageá-lo com a dedicação de um nome.)

Dezesseis espécies de cobras foram descritas como novas e como tal se mantêm: Coluber poecilostoma (Pseustes sulphureus poecilostoma), C. liocercus (Leptophis ahaetulla liocercus), C. bicarinatus (Chironius), C. pyrrhopogon(Chironius), C. laevicollis (Chironius), C. carinicaudus (Helicops), C. plumbeus (Clelia), C. undulatus (Liophis), C. merremii (Liophis miliaris merremii), C. rabdocephalus (Xenodon), C. poecilogyrus (Liophis), C. formosus (Oxyrhopus), C. venustissimus (Erythrolamprus), Lachesis rhombeata, Cophias jararaca (Bothrops), Cophias bilineatus (Bothrops).

Oito espécies descritas como novas revelaram-se sinônimos: Coluber variabilis $=$ Spilotes pullatus (L.); C. lichtensteinii = Mastigodryas bifossatus (Raddi); $C$. acuminatus = Oxybelis aeneus (Wagler); $C$. dictyodes = Liophis miliaris $(\mathrm{L}) ;$.$C . pileatus$ e C. herbeus, ambos Philodryas olfersii (Lichtenstein); C. saurocephalus $=$ Xenodon severus (L.); C. doliatus, o jovem de Liophis poecilogyrus (Wied); Elaps corallinus, sinônimo e homônimo de Micrurus corallinus (Merrem), como comentado acima; Elaps marcgravii = Micrurus ibiboboca (Merrem), caso idêntico ao anterior.

Cabem aqui duas observações. Coluber aeneus só recentemente veio a substituir Oxybelis acuminatus. As razões são puramente nomenclaturais, tendo o conceito da espécie se formado e aperfeiçoado em torno do nome de Wied. C. doliatus, como dito, é o jovem de C. poecilogyrus; Wied desconfiou 
do caso, mas acabou cometendo sua única dupla sinonímia em serpentes.

Finalmente, há 7 nomes de Wied cujos tipos não sobreviveram e cujas descrições originais não resultaram em caracterização de espécies: Coluber testaceus, C. modestus, C. collaris, C. marginatus, C. erythrogaster, Cophias holosericeus, Typhlops leucogaster.

Tive, como dito, recentemente a oportunidade de rever os répteis sobreviventes da coleção de Wied no American Museum of Natural History. É realmente impressionante a precisão das medidas e das contagens de escamas feitas por Wied e a qualidade das ilustrações, quanto aos detalhes técnicos. Reconhece-se sem a menor dificuldade qualquer exemplar descrito nas Beitraege.

\subsubsection{Anfíbios}

Como se poderia esperar de uma viagem para a frente, feita antes do advento da lanterna elétrica, a coleta de anfíbios de Wied foi fraca, e ele pouco se dedicou à coleção. Não se preocupou sequer com a citação cruzada entre Beitraege e Reise, tão cuidada e tão útil no caso das aves.

Apenas 16 espécies são citadas, compreendendo Mata Atlântica e regiões interiores; 10 são propostas como novas. Destas, 6 permanecem: Bufo crucifer, Hyla faber, $H$. crepitans, H. elegans (Scinax), Ceratophrys boiei (Proceratophrys). Os 4 sinônimos são Bufo fuliginosus $=$ B. ictericus $($ Spix); B. cinctus $=$ B.crucifer $($ Wied $) ;$ Ceratophrys dorsata $=$ C. aurita (Raddi) e Rana sibilatrix = Leptodactylus fuscus (Schneider). A sinonímia entre $B$. cinctus e $B$. crucifer é a única sinonímia dupla de Wied em anfíbios. Em resumo, um finíssimo zoólogo.

\subsection{A missão austríaca}

Por ocasião do casamento de D. Pedro (futuro Primeiro) com D. Leopoldina, em 1817 , veio ao Brasil no séquito da noiva uma luzida comissão técnica - aliás, três luzidas comissões técnicas. Um conjunto de valor comensurável com o da nova imperatriz.

O grupo mais numeroso, o austríaco, era constituído pelo naturalista tcheco Johann
Christian Mikan, pelos coletores Johann Natterer e Dominick Sochor, pelo jardineiro (encarregado da introdução de plantas vivas na Europa, uma tarefa de primeira importância na época) Heinrich Schott, pelos pintores Thomas Ender, Franz Joseph Frübeck e Johann Buchberger, e pelo bibliotecário e curador de coleções Rochus Schüch, ninguém menos que o futuro primeiro barão de Capanema (Ramirez, 1968).

O segundo grupo, bávaro, era o já comentado de Spix e Martius, imensamente superior aos demais. O terceiro grupo constava unicamente do naturalista italiano Giuseppe Raddi.

Empregando o critério de relevância zoológica, podemos descartar de início Mikan (1820-25) e Raddi (1820, 1822). Publicaram alguns poucos trabalhos sem expressão, contendo espécies novas, mas sem impacto que se diga. Do ponto de vista zoológico o homem forte da expedição foi Natterer. Por 18 anos coletou ele no Brasil quase inteiro (Vanzolini, 1993) acompanhado por Sochor, até que este morreu de malária em Mato Grosso, em 1826. Natterer continuou firme até 1835 , quando voltou (casado naturalmente com brasileira) à Áustria, para estudar seu material - uma das melhores e mais bem preparadas coleções jamais feitas no mundo. Natterer foi não só um bom taxidermista (ver exemplos de suas peças em Schifter, 1983), mas, mais importante, foi um dos introdutores de anotar-se, em uma etiqueta individual para cada espécime, localidade, data, sexo, medidas e informações sobre a cor das partes moles (Stresemann, 1975, p. 209; estranhamente não encontro este trecho no original alemão; talvez se trate de uma interpolação silenciosa de G. W. de Cottrell, o comentador da tradução de 1975.)

Natterer não viveu para descrever seus materiais; o que publicou foi pouco e sem grande importância. Aparentemente não era tão bom no museu quanto no campo. Além disso, havia passado 18 anos longe da civilização, longe do movimento científico, justamente durante uma fase explosiva do conhecimento das avifaunas. Deve ter perdido o contato. Morreu em 1843, tendo publicado apenas dois trabalhos. Um, em colaboração com L. Fitzinger (Natterer, 1840), sobre os 
jacarés do Brasil, lindamente ilustrado e contendo dados principalmente de biologia e distribuição (Vanzolini, 1977, p. 60). O outro trabalho (Natterer, 1837) versa sobre a pirambola, que havia sido descrita por Fitzinger (1836) com base em um exemplar coletado por Natterer (ver também Fitzinger, 1837).

Jacob Heckel (1840) publicou uma primeira memória (sem continuidade) sobre os peixes fluviais de Natterer. Ocupou-se apenas de uma fração da coleção: 50 espécies, das quais 48 de Cichlidae, 1 de Sciaenidae e 1 de Polycentridae. Quarenta e nove espécies são descritas como novas.

É muito ilustrativo considerar o problema das sinonímias de Heckel. Nenhuma de suas espécies é sinônimo de forma anteriormente descrita. Por outro lado, sua sinonímia interna é desoladora. Duas espécies receberam 5 nomes cada; duas receberam três; nove receberam dois nomes. Vê-se que era uma fauna nova e muito individualizada, estudada por um autor inexperiente.

As localidades não eram muitas: rio $\mathrm{Ne}$ gro (sem mais), Marabitanas, Manaus, Rio Branco (sem mais), rio Guaporé em Vila Bela, rio Paraguai em Cáceres, Cuiabá.

Os demais peixes, os répteis e os anfíbios das coleções de Natterer foram parceladamente estudados por diversos autores, especialmente Kner (peixes) e Steindachner.

Coube a August von Pelzeln desfrutar as coleções brasileiras de aves e mamíferos, publicando aqueles em 1868-70 e estes em 1886. Os artigos de Pelzeln são compactos e proficientes; colocam ordem em um belo acervo de 12.293 peles de aproximadamente 1.200 espécies. Dá ele sempre escrupulosamente crédito a Natterer por espécies que este tenha deixado reconhecidas em notas de campo. Levantou inestimáveis dados sobre os itinerários. Infelizmente, ao saírem os artigos, estava quebrado o fio do pioneirismo. As faunas já estavam bem caracterizadas; a necessidade passara a ser de trabalhos de caráter monográfico, não-faunístico e, principalmente, faunísticos de uma área tão grande e heterogênea quanto o Brasil. Pelzeln, indispensável à ornitologia brasileira, sequer é mencionado na História da Ornitologia de Erwin Stresemann (1951,1975).

\subsection{Castelnau}

Francis de la Porte, conde de Castelnau, misto de diplomata de carreira e naturalista, veio à América do Sul chefiando uma missão científica oficial do governo francês, parte do grande ciclo de explorações geográficas empreendido pela França. Completavam a equipe Émile Deville, preparador do Museu de Paris e zoólogo, Eugène Osery, engenheiro de minas (morto no Peru pelos índios jeberos), e Hugh A. Weddell, botânico.

O extenso itinerário ("do Rio de Janeiro a Lima, e de Lima ao Pará”) teve duas fases brasileiras (Papavero, 1971). A primeira, entre o Rio de Janeiro, que deixaram em outubro de 1843, e a entrada na Bolívia, por Casalvasco, próximo a Vila Bela da Santíssima Trindade, em fins de junho de 1845. As etapas foram: (i) do Rio de Janeiro a Belo Horizonte; (ii) a Goiás Velho; (iii) ao rio Araguaia, descendo o rio Crixás a partir da vila de Crixás, em Goiás; (iv) descendo o Araguaia até a confluência com o Tocantins e subindo este até Peixe; (v) volta por terra a Goiás Velho; (vi) a Cuiabá; (vii) descendo os rios Cuiabá e Paraguai até Forte Olimpo, no Paraguai; (viii) subindo o rio Paraguai até Cáceres; (ix) a Vila Bela da Santíssima Trindade; (x) por Casalvasco à Bolívia. Ao todo pouco mais de vinte meses.

Na Bolívia a expedição subiu os Andes via Potosi e Oruro até La Paz e o lago Titicaca, realizando, além dos trabalhos de história natural, importantes explorações arqueológicas pioneiras. Do altiplano boliviano seguiram para Puno, no Peru; daí por Arequipa passaram à costa, onde separaram-se em dois grupos; um seguiu para Lima embarcado, o outro por terra.

De Lima seguiram para Cuzco, pelo antigo caminho dos Incas. De Cuzco desceram o rio Urubamba e, sucessivamente, o Ucayali e o Amazonas até Belém, que alcançaram em meados de março de 1847.

Considero a reentrada em nossa área de interesse (segunda fase brasileira) como acontecendo em Sarayacu, no Ucayali, importan- 
tíssima localidade-tipo da expedição (incluindo a vizinha Pampa del Sacramento, na estrada Pucallpa-Tingo Maria), e lugar de fauna francamente amazônica; excluo destas notas apenas o material puramente andino. Depois de uma parada em Pebas, no Solimões, pouco foi coletado até Belém, de onde a expedição seguiu para as Guianas, e destas para as Antilhas, regressando a Paris em julho de 1847, gastos cerca de 49 meses no campo.

Castelnau voltou ao Brasil pouco depois, como cônsul da França em Salvador, de onde ainda mandou a Paris material herpetológico, como narrado abaixo. Aí teria ainda (Papavero, 1971) escrito a narrativa da viagem, cujo primeiro volume foi publicado em 1850. São ao todo seis volumes, os quatro primeiros dedicados ao Brasil; o sexto, por Weddell, relata suas pesquisas, principalmente paleontológicas, na Bolívia.

A narrativa de Castelnau (1850-51, 1949) é precisa e minuciosa; não deixa dúvidas quanto aos lugares visitados e contém sólida informação ecológica.

Depois de Salvador, Castelnau assumiu outros postos consulares, na África do Sul e na Austrália, tendo publicado sobre os peixes e os insetos de ambas as regiões. Morreu na Austrália em 1880.

O outro zoólogo da expedição, Émile Deville, após publicar alguns artigos científicos em Paris, voltou ao Brasil, e morreu em 1853 no Rio de Janeiro, de febre amarela, moléstia que pretendia estudar (Des Murs, 1855-56, p. 2).

A publicação dos resultados da expedição seguiu o então novo modelo adotado pelos grandes empreendimentos franceses, ou seja, caráter enciclopédico, com a colaboração de numerosos especialistas. (Para uma idéia mais precisa, ver British Museum, 1904, sob "France [Voyages \&c.]".) Note-se, especialmente (do ponto de vista do Brasil), a inclusão, pela primeira vez, de um forte contingente de zoologia de invertebrados: insetos, aracnídeos, crustáceos, miriápodos, moluscos e outros grupos marinhos.

Como dito, os quatro primeiros volumes tratam da viagem. Há na série volumes especiais sobre vues et scènes, arqueologia incaica, geologia, geografia (inclusive iti- nerários) e botânica. A parte da viagem referente ao Brasil foi publicada pela "Brasiliana" (Castelnau, 1949) em tradução simples, sem comentários.

Em outubro de 1844 Castelnau havia escrito uma carta ao ministro da Instrução Pública, relatando suas viagens em Goiás, descendo o Araguaia e subindo o Tocantins; esse relatório foi publicado pelo Instituto Histórico e Geográfico Brasileiro em 1866.

A proclamação da República francesa em fevereiro de 1848 e o golpe de Napoleão III em dezembro de 1852, com inevitável perturbação da ordem pública, atrasaram a publicação da obra. Por isso os zoólogos da equipe publicaram em revistas parte dos resultados zoológicos: Deville (1849, 1851, 1852a, 1852b); Deville e Des Murs (1849a, b); Deville e Sclater (1852); I. Geoffroy SaintHilaire (1850, 1851a); I. Geoffroy SaintHilaire e Deville (1848). Des Murs (1855-56, p. 1) queixa-se da antecipação das descrições originais de espécies.

Um detalhe é que, no tratamento conjunto, nem sempre a ordem dos autores é a mesma que no título do trabalho em revista. Também Castelnau recebe freqüente crédito por trabalhos que não assinou.

Os dois volumes da obra total, publicados em livraisons em 1855 e 1856, tinham como título geral Animaux Nouveaux ou Rares Recueillis Pendant l'Expédition dans les Parties Centrales de l'Amérique du Sud, de Rio de Janeiro a Lima, et de Lima au Para; Exécutée par Ordre du Gouvernement Français Pendant les Années de 1843 a 1847 , sous la Direction du Comte Francis de Castelnau. As datas das livraisons foram recuperadas por Sherborn e Woodward (1901), que acompanho aqui.

O primeiro volume contém os mamíferos e as aves.

\subsubsection{Mamíferos}

Isidore Geoffroy e Deville publicaram em 1848 oito novas espécies de macacos (notese mais uma vez a ênfase da época, nos macacos e morcegos). Das oito espécies sobrevive Chiropotes albinasus, o cuxiú. Em 1850 Isidore publicou mais três espécies. Uma, 
como podemos dizer, "de costume", é sinônimo de Cebus apella, e duas de Saguinus fuscicollis - completando três sinônimos (double employ) de Isidore para esta espécie, que ocorre no Brasil.

Deville descreveu em 1849 um macaco novo da Bolívia, sinônimo também de Saguinus fuscicollis e em 1852 um gênero e espécie novos de roedores (Lasiusomys villosus), sinônimo de Isothrix histriata (Wagner).

Na obra geral o tratamento dos mamíferos é mal organizado e confuso. Sou forçado a dar uma tabela explicativa.

\section{“ANIMAUX NOUVEAUX OU RARES, TOME PREMIER}

Anatomie (P. Gervais)

Recherches sur les mammifères fossiles de l'Amérique du Sud (P. Gervais) [a palavra 'fossiles' é omitida no índice].

Description ostéologique de l'Hoazin, du Kamichi, du Cariama et du Savacou, suivie de remarques sur les affinités naturelles des oiseaux (P. Gervais).

Ostéologie de la tête du Vastrès et du Mylétès ( $P$. Gervais).

Remarques ostéologiques sur les genres Brachyure et Callitriche de la tribu des singes américains (P. Gervais).

Anthropologie, Note explicative des planches consacrées àl'Anthropologie ( $P$. Gervais).

Mammifères (P. Gervais).

Primates (Isidore Geoffroy Saint-Hilaire) Documents zoologiques pour servir à la monographie des Cheiroptères sud américains (P. Gervais).

Description des trois espèces de dauphins qui vivent dans la région du haut Amazone (P. Gervais).

Sur quelques points de l'histoire zoologique des Sarigues, et, plus particulièrement, sur leur système dentaire (P. Gervais).

Description d'un nouveau genre de Rongeurs, sous le nom de Lasiuromys ( $E$. Deville).

Énumeration des principales espèces de Mammifères recueillis pendant l'expédition dans les parties centrales de l'Amérique du Sud (P. Gervais)".

O trabalho de Gervais sobre mamíferos fósseis, baseado principalmente em uma bela coleção feita por Weddell, não nos concerne aqui, mas é muito bonito e importante.

As descrições do Hoazin, etc., tratandose de aves, serão tratadas no contexto.

O "Vastrès" (pirarucu) e o "Mylétès" (pacu) são peixes e ficam também para a ocasião.

Os gêneros Brachyurus (= Cacajao) e Callitrix (= Callicebus) são cebídeos, e as notas de Gervais são importantes. (No índice do volume está grafado, por engano, "Lagotriche" em vez de "Callitriche".)

As pranchas antropológicas são de crânios indígenas, com exceção de uma, linda, de uma cabeça mumificada pelos índios mundurucus. É característico do pensamento europeu da época as raças indígenas serem estudadas por mamalogistas.

O capítulo de Isidore Geoffroy sobre primatas encaixa os macacos da expedição em um sistema genérico baseado em caracteres externos. Vinte e uma espécies são alistadas; nenhuma é descrita como nova, as novidades já havendo sido apresentadas por Geoffroy e Deville (1848). Éum trabalho sem importância.

Os "documentos zoológicos" são um pródromo da sistemática dos morcegos sulamericanos. São comentadas, em diversas profundidades, 55 espécies, apenas 13 coletadas na viagem; dessas, 4 descritas como novas. Duas subsistem: Micronycteris minuta e Lasiurus ega.

No trabalho sobre botos, Gervais reconhece corretamente Inia geoffrensis ("le dauphin rapporté de Lisbonne", ver acima 
Alexandre Rodrigues Ferreira) e descreve duas vezes como novo o tucuxi, Sotalia fluviatilis.

O artigo sobre "sarigues" (didelphídeos) é uma excelente contribuição ao estudo dos marsupiais sul-americanos ao nível de gênero.

O trabalho de Deville (já então falecido) sobre Lasiuromys é uma republicação do artigo de 1852.

Finalmente, a enumeração das 11 "espécies importantes" coletadas é acompanhada de comentários sem grande interesse.

\subsubsection{A ves}

A coleção de aves de Castelnau é numericamente modesta, especialmente considerando-se que ele viajou durante mais de quatro anos por mata atlântica, cerrado, pantanal, pré-cordilheira e cordilheira andinas, costa do Pacífico e hiléia. Des Murs, o responsável pela obra de conjunto em aves, alista 73 espécies, das quais 62 do Brasil ou de regiões assimiladas (preponderantemente de Sarayacu, no Ucayali). Parece ter havido perdas de material em viagem (Guichenot, 185556, p. 1).

Dessas 62 espécies 28, quase a metade, foram descritas como novas e 18 assim se mantêm. Há apenas um caso de sinonímia interna (uma mesma espécie descrita duas vezes como nova). É um resultado cientificamente bom, embora faunisticamente pobre.

Há, porém, na coleção e na obra de Castelnau, três aspectos não-faunísticos muito fortes: observações ecológicas, dissecções anatômicas, no campo, de peças frescas, e coleção de esqueletos completos.

As observações ecológicas, incidentais e desprovidas ainda de orientação teórica, não são importantes em si, mas marcam uma tendência. Ao contrário, os estudos anatômicos, rigorosamente na escola de Cuvier, são importantes. Deles resultaram contribuições expressivas à sistemática acima do nível de espécie. Refiro-me aqui principalmente ao estudo sobre a cigana ("hoazin", Opisthocomus hoatzin), a anhuma ("kamichi", Anhima cornuta), a seriema ("cariama", Cariama cristata) e o arapapá ("savacou”,

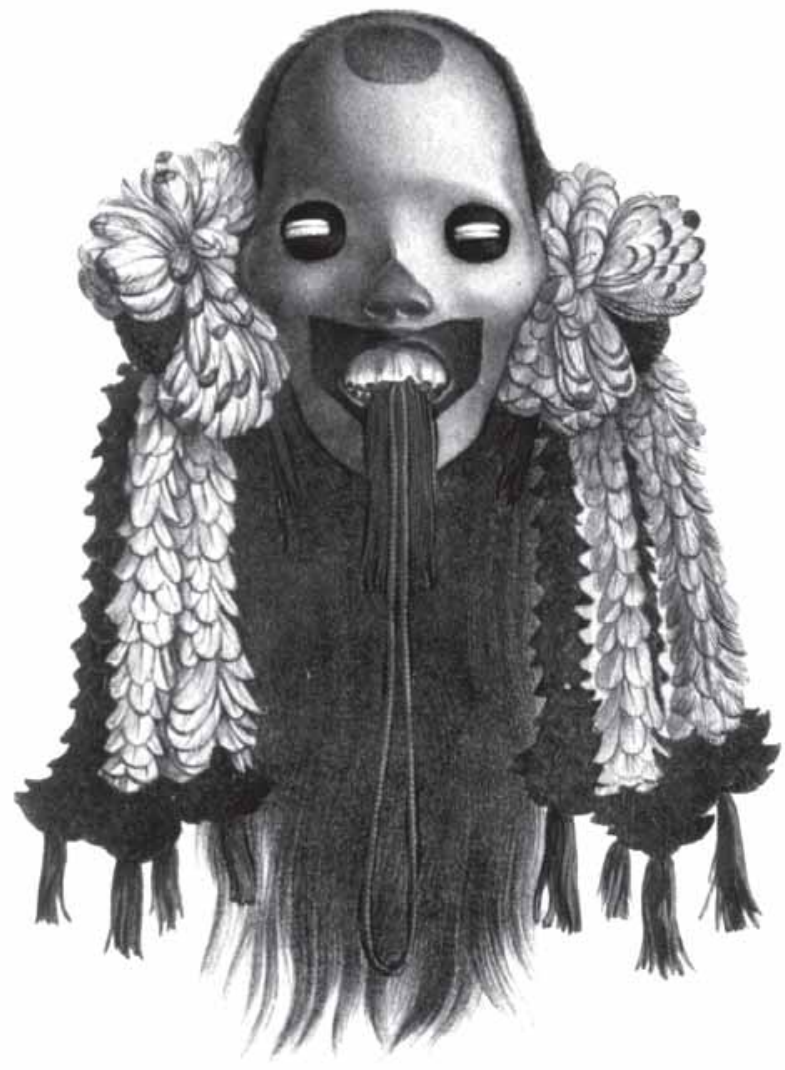

Cochlearius cochlearius). São aves de posição sistemática peculiar, pertencentes a grupos monoespecíficos, cujas relações só podem ser analisadas à luz da anatomia. A própria consideração dos resultados parciais levantou problemas de ordem geral, interessando a todo o sistema das aves e levando a mudanças e aperfeiçoamentos. Paul Gervais era eminentemente qualificado para a tarefa (paleontólogos são tradicionalmente finos osteologistas), mas o discernimento em planejar e executar as coletas e preparar os materiais foi obviamente dos zoólogos de campo. Não está claro quem tenha realizado as dissecções; provavelmente Deville, que era preparador de seu ofício. Os dados, porém, foram colocados à disposição dos sistematas, para uso eficiente.

\subsubsection{Répteis}

A coleção de répteis da expedição de Castelnau não é de primeira ordem, seja pela quantidade, pela qualidade, ou pelo tratamento. Inclui 10 espécies de tartarugas, uma de jacaré, 26 de lagartos e 40 de serpentes. Dessas espécies, 10 não foram coletadas durante
Litografia do livro

Expéditions dan les parties centrales de I'Amerique du Sud..., do conde de C astelnau(Paris, 1850-59), Biblioteca do IE B - USP 
a viagem, mas enviadas posteriormente da Bahia por Castelnau. Duas foram coletadas na Guiana, mas são aqui incluídas por terem ampla distribuição no Brasil.

Guichenot (1855-56, p. 1), como dito, refere perda de materiais em viagem. Não entendo, porém, Castelnau ter atravessado o altiplano da Bolívia sem fazer chegar a Paris sequer um Liolaemus do grupo multiformis.

Nas publicações anteriores à obra de conjunto, quatro espécies novas haviam sido descritas sobre materiais da viagem: Anolis transversalis (Duméril e Duméril, 1851); Apostolepis flavotorquata (Duméril, Bibron e Duméril, 1854); Bothrops castelnaudi (Duméril, Bibrone Duméril, 1854)e Bothrops alternatus (Duméril, Bibrone Duméril, 1854). $\mathrm{Na}$ obra de conjunto a parte herpetológica ficou a cargo de A. Guichenot, herpetologista de vôo mediano, que descreveu três espécies novas: Gymnodactylus (= Gonatodes) humeralis; Enyalus (= Enyalioides) laticeps e Enyalus planiceps, sinônimo da anterior, e da mesma localidade.

Há alguns problemas aborrecidos. As espécies nominais Salvator merianae e $S$. nigropunctatus são explicitamente ditas ocorrerem em simpatria em "várias localidades" brasileiras (não especificadas). Salvator é um sinônimo de Tupinambis e não há localidade brasileira onde dois Tupinambis sejam simpátricos.

Na realidade, há diversos outros problemas sérios de localidades na coleção. As localidades peruanas de Pebas e Nauta são mais de uma vez atribuídas ao Brasil. Na descrição original de Bothrops castelnaudi (Duméril, Bibron e Duméril, 1854, p. 1511) é declarado que a localidade-tipo não era conhecida; Guichenot (1855-56, p. 76) diz que o exemplar vem de Goiás; a espécie não ocorre em Goiás. Outras espécies são assinaladas em áreas onde se sabe que não ocorrem: Platemys hilarii do rio Amazonas; Neusticurus bicarinatus de Nauta; Leposternon scutigerum do rio Araguaia; Anilius scytale e Xenodon severus da Bahia; Bothrops jararaca de Mato Grosso e Goiás. Essas discrepâncias podem dever-se, no geral, a dois tipos de causa: erros de identificação ou de rotulagem (má curatoria). No caso de $B$. jararaca poderia ter havido confusão com B. moojeni, que viria a ser descrita muito mais tarde. No caso do Leposternon também poderia ter havido confusão com L. infraorbitale; o gênero é difícil. Nos demais casos, porém, não é crível que o Museu de Paris errasse as identificações; no caso de $P$. hilarii, sobretudo, há no livro uma linda prancha que não deixa dúvida sobre a determinação, além do que o tipo está em Paris. Somos obrigados a crer em confusão de localidades na coleção de Castelnau. Além disso, há 27 espécies (34\% do total de 79) sem localidade ou (o que dá no mesmo) com a localidade vaga "Brésil".

\subsubsection{Anfíbios}

Não houve publicação prévia sobre anfíbios de Castelnau; há apenas o tratamento por Guichenot, no mesmo capítulo dos répteis. São alistadas poucas espécies (15), todas comuns e plausíveis, nenhuma nova. Não há comentário de significância; é um capítulo muito bem ilustrado e morto.

Tenho a impressão de que, após o ponto alto representado pela Erpétologie Générale de Duméril e Bibron, este capítulo de Guichenot marca o início da decadência da herpetologia francesa no século XIX.

\subsubsection{Peixes}

A coleção de peixes de Castelnau, que não foi objeto de publicação prévia, e que foi tratada na obra de conjunto pelo próprio Castelnau, é tão grande que só é possível, nos limites deste trabalho, tratá-la estatisticamente. Aliás, isto em si já é um comentário sobre a importância do material.

São alistadas 264 espécies; 5 são de fora de nossa área e 30 não consegui identificar; os cálculos abaixo são feitos sobre 229 espécies.

São descritas como novas 95 (41\%), das quais $35(37 \%)$ consideradas correntemente como válidas. São números consistentes com os dos grandes viajantes da época.

Os sinônimos apresentam alguns aspectos interessantes. Há apenas 7 espécies descritas duas vezes e uma descrita três vezes, Geophagus brasiliensis, o acará mais comum e mais amplamente distribuído do Brasil. 
Dezesseis nomes são sinônimos de espécies cujos tipos estavam no Museu de Paris. Penso que isso reforça a hipótese de que Castelnau não tenha escrito sua obra no museu.

Sendo esta a única coleção de Castelnau que tem interesse faunístico, é necessário considerar as localidades.

No caso de peixes marinhos apenas duas localidades são citadas: Rio de Janeiro, o início da expedição, e Bahia, sem dúvida a fase consular de Castelnau em Salvador. São alistadas 124 espécies, pertencentes a 14 famílias. Vinte são descritas como novas, 8 são válidas.

Quanto às localidades fluviais, o Amazonas é mencionado a respeito de 50 espécies, a bacia do Araguaia 47 vezes, o Ucayali (incluindo o Urubamba) 22 e o Tocantins 13. Houve alguma coleta de água doce na Bahia (6 espécies) e coleta ocasional em localidades de Minas Gerais (bacias do São Francisco e do Paraná).

Como se vê, uma contribuição fundamental.

O capítulo (Gervais, 1856) sobre a anatomia craniana do pirarucu (Arapaima gigas) e de um pacu grande (Colossoma bidens) é puramente descritivo, sem contribuição à anatomia comparada ou à sistemática.

\subsubsection{Comentário}

A contribuição de Castelnau mostra três faces distintas. Os mamíferos e aves têm pouca importância faunística, ou seja, para o conhecimento da fauna sul-americana; a contribuição à sistemática acima do nível de espécie é importante. Os peixes têm grande importância faunística, comparável à de Spix e Agassiz, mas não ensejaram outros tipos de estudo. Os répteis e anfíbios são medíocres sob ambos aspectos.

\subsection{Langsdorff}

A expedição do barão alemão e cônsul russo Georg Heinrich (ou Grigori Ivanovich, como preferiam os soviéticos) Langsdorff tornou-se notória por diversas razões, nenhuma delas zoológica. A história da viagem seria até pitoresca, não fossem dois dolorosos acontecimentos, a morte no campo do jovem artis- ta plástico Aimé-Adrien Taunay e a rápida e completa deterioração mental de Langsdorff, que terminou a viagem louco e inválido.

Langsdorff, que tinha conhecido o Brasil de passagem, como membro da viagem de Krusenstern (Papavero, 1971, p. 50), conseguiu o lugar de cônsul russo no Rio de Janeiro (falava português por ter servido como médico militar em Portugal) com a intenção de ter acesso contínuo à natureza tropical. Chegou em 1813 e ficou, em uma primeira fase, até 1820. Tinha uma confortável casa na cidade e, principalmente, uma finíssima casa de campo, a fazenda Mandioca, na rampa da Serra dos Órgãos, em plena Mata Atlântica. Ali recebia com generosidade e em ambiente culto os viajantes científicos que começavam a afluir ao Brasil; praticamente todos se referem ao fato em suas memórias de viagem. Foi na casa de Langsdorff que o príncipe de Wied conheceu os coletores Freyreirs e Sellow (Papavero, 1971, p. 58).

Contei em Sherborn (1902) 42 nomes específicos homenageando Spix, 36 Langsdorff, 9 Max zu Wied-Neuwied e 6 Castelnau. Parece-me óbvio um forte componente afetivo nas homenagens a Langsdorff, em número tão desproporcional a sua importância científica.

Langsdorff ficou no Rio de Janeiro de 1813 a 1820, quando voltou à Europa. Veio de novo ao Brasil em 1822, saindo para uma longamente sonhada expedição em 1826, depois de diversos adiamentos e peripécias. Nesse ínterim realizou duas excursões de média duração a Minas Gerais, seguindo a estrada real daqueles tempos, por Juiz de Fora e Barbacena a Ouro Preto, capital da província. Em junho de 1826 deu a saída à expedição propriamente dita.

O itinerário (Papavero, 1971) foi dos mais interessantes, e vem descrito com muito charme por Hercules Florence (1875-76, 1929, 1941). Uma primeira fase foi de Porto Feliz em São Paulo a Cuiabá no Mato Grosso. Previamente, de Porto Feliz fizeram uma digressão pela estrada das tropas até Castro no Paraná. Não deixaram, como bons alemães, de visitar a fábrica de ferro de Ipanema. Em seguimento, a expedição fez o velho caminho das monções paulistas: descendo o Tietê até 
o Paraná, subindo este e entrando pelo Pardo até as cabeceiras do pequeno afluente Camapuã, passando por terra (duas léguas e meia no carro-de-boi) para as cabeceiras do Coxim e por ele abaixo, e pelo Taquari, até o rio Paraguai; subindo sucessivamente este, o São Lourenço e o Cuiabá até a cidade.

Em Cuiabá pararam dez meses, sendo empreendida uma viagem colateral por Cáceres até Vila Bela da Santíssima Trindade. Durante esta viagem Taunay afogou-se no alto Guaporé. Riedel, que estava com ele, desceu o Guaporé e o Mamoré até o Madeira, para o Amazonas e Belém. O resto da expedição, com Langsdorff, tomou de novo o caminho dos bandeirantes, descendo o Preto, a partir de Diamantino (no divisor de águas entre as bacias do Amazonas e do Prata) e depois o Arinos, o Juruena e o Tapajós até Santarém.

Havia um propósito de seguir para Manaus e subir o Negro, saindo nas Guianas (Garcia, 1922, p. 885), mas as condições de saúde de Langsdorff não permitiram. Em Santarém foi dada a expedição por terminada, em primeiro de julho de 1828.

Langsdorff, por todos testemunhos, um homem culturalmente muito interessante, teve (não simultaneamente) a colaboração de três excelentes ilustradores, Johann Moritz Rugendas, Aimé-Adrien Taunay e Hercules Florence. As obras desses artistas, desde manchas e esboços até retratos acabados, constituem um inapreciável documentário, social e etnográfico, daquele Brasil desconhecido - isso sem mencionar a fina qualidade artística. Em 1988, a Academia de Ciências da então União Soviética fez publicar essa iconografia, em três álbuns, um para cada artista, com um excelente histórico da viagem por Boris N. Komissarov (ver também 1988) e farta bibliografia (ver, na Bibliografia abaixo, Expedição Langsdorff ao Brasil, 1821-1829).

A expedição contava com um astrônomo (na conjuntura com funções de geógrafo), $\mathrm{N}$. G. Rubsov, que não entra na nossa história; com um botânico, Ludwig Riedel, homem metódico e cumpridor, que coletou muito e, quando exigido, assumiu as responsabilidades de Langsdorff enfermo; tampouco parti- cipa da saga zoológica. Esta é a província de Edouard Ménétriès e dos ilustradores.

Ménétriès foi contratado como zoólogo da expediçãoaindana Rússia. VeiocomLangsdorff ao Brasil, onde, antes da expedição, trabalhou bastante nos estados do Rio de Janeiro e Minas Gerais. No Rio desentendeu-se comLangsdorff e, em fevereiro de 1825 (Pinto, 1952, p. 6) voltou à Rússia, onde se estabeleceu até a morte. Para substituí-lo na expedição foi contratado Christian Hasse. Este, contudo, meteu-se em complicações amorosas (a moça casou-se com Florence e entroncaram uma família ilustre em Campinas) e abandonou a expedição (Garcia, 1922, p. 886). Langsdorff cruzou o Brasil sem zoólogo.

Na década de 1980, como dito, houve um curioso e intenso esforço propagandístico do governo soviético, de toda maneira promovendo a expedição, com exposições internacionais, acompanhadas por combativos intelectuais, edição de catálogos e panfletos, culminando na publicação da obra acima referida, em três volumes (ver também Chur, 1981). A apresentação desses álbuns começa da seguinte maneira: “A expedição Langsdorff (1821-29) representa um dos mais importantes acontecimentos culturais e científicos do Brasil [...]". Zoologicamente falando, nada mais errado. Ressalvado o valor dos desenhos e aquarelas, o demais da expedição foi um triste fracasso.

Strauch (1889) escreveu, por ocasião do qüinquagésimo aniversário, uma detalhada história e descrição do museu de São Petersburgo. Langsdorff é mencionado três vezes, por "valiosas" ("beträchtlich", um termo convencional) coleções de peles (“Bälgen") de mamíferos, aves e peixes (pp. 147, 172, 205). Komissarov (1988, p. 33) afirma que há no museu cerca de mil exemplares coletados por Langsdorff. Acredito, mas o relevante no presente contexto é saber que uso foi feito desses materiais, em época útil, para adiantar a pesquisa zoológica.

Tanto quanto pude averiguar, foram publicados dois artigos de pesquisa sobre materiais zoológicos de Langsdorff. Um é a revisão das aves do grupo das Myiotherinae (então na família Formicariidae) por Ménétriès (1835). O outro é um trabalho de Brandt 
(1835), diretor do museu de São Petersburgo.

Em sua revisão (que abrange, na verdade, por critérios atuais, três famílias) Ménétriès descreveu onze espécies novas. Seu trabalho foi revisto por Chrostowski (1921) e Hellmayr (1924). São consideradas válidas oito dessas formas, uma excelente proporção. É óbvio que todos os exemplares vieram da coleção de Langsdorff, mas não obrigatoriamente da expedição propriamente dita. Muitos devem ter sido coletados por Langsdorff e Ménétriès durante a estada do primeiro como cônsul no Rio de Janeiro.

De fato, as localidades-tipo são Cuiabá (3 espécies), Rio de Janeiro (2), São João del Rei (1) e Minas Gerais (2), sem mais. Com exceção de Cuiabá as localidades indicam claramente coleta anterior à expedição, durante a residência de Langsdorff no Rio de Janeiro.

Quanto a Cuiabá, que seria uma localidade normal, dado que a expedição lá demorou dez meses, há problemas. Aparentemente, alguns dos exemplares atribuídos por Ménétriès a essa localidade pertencem a formas que aí não ocorrem. Reinhardt (1870, p. 366) acompanhado por Hellmayr (1924, p. 204) pensa que "Cuyaba" no caso não seja a cidade mato-grossense, mas uma mina de ouro "não longe" de Sabará (na realidade em Caeté), onde Langsdorff possivelmente tivesse estado. Acho essa hipótese fraquíssima.

A existirem razões ornitológicas muito fortes para duvidar da localidade-tipo, é sempre preferível deixá-la como duvidosa a substituí-la por outra, proposta engenhosamente mas sem apoio factual, ou seja, sem referência a um exemplar-tipo. Aliás, se a localidade não fosse a cidade de Cuiabá, de todos conhecida, e sim uma obscura mina em outro estado, Ménétriès, que conhecia muito bem o Brasil, teria sido o primeiro a chamar a atenção para o fato.

Para mim este caso significa apenas que não se pode ter confiança completa na etiquetagem. Ou, é claro, em Hellmayr. Finalmente, esse tipo de mudança de localidade-tipo não tem valor junto às "regras". Localidade-tipo é a localidade do tipo, e o tipo é um indivíduo físico, é um exemplar, não um conceito.
O mesmo Hellmayr (1924, p. 27) descarta Cuiabá como localidade-tipo de outra espécie de Ménétriès, Conopophaga melanogaster, e propõe que seja substituída por "rio Madeira". A tolice aqui é dupla. A nova localidade é de novo proposta sem discussão dos eventuais indícios que a tornariam, senão provável, ao menos aceitável. Quem desceu o Madeira foi Riedel (o resto da expedição desceu o Tapajós); não há documentação publicada de sua viagem. Não se sabe, por exemplo, sequer, se esse botânico coletou aves. Em segundo lugar, o rio Madeira não é uma "localidade": tem cerca de 1.300 km de extensão. Cientistas dogmáticos, como Hellmayr, por mais competentes que sejam, acabam cometendo disparates desses.

O artigo de Brandt (1835) é heterogêneo, tanto quanto à abrangência sistemática (inclui várias subordens de roedores) quanto à geográfica (cobre 4 continentes). Das 17 espécies tratadas 11 são sul-americanas, 6 descritas como novas. A autoria de uma delas é explicitamente atribuída a Langsdorff, em uma carta escrita de Ipanema - que eu saiba o único testemunho da competência científica de Langsdorff. Essa carta não mais existe (N. Komissarov, comunicação pessoal). Uma das espécies novas é válida, a presente Galea flavidens. Um novo gênero proposto, Holochilus, é válido, embora a espécie-tipo seja um sinônimo. Os materiais declaradamente atribuídos à coleção de Langsdorff referem-se a 8 espécies. Uma é válida (a citada Galea) e uma tem situação complicada até hoje (Mus anguya, um Oryzomys). Ménétriès contribuiu com uma espécie. Não é muito.

\subsubsection{Comentário}

Curiosamente, a literatura sobre Langsdorff é muito sectária, apaixonada em desproporção com a importância científica da contribuição. Contudo, nem os mais exaltados defensores (em 1985 um dos debatedores russos quase me agrediu fisicamente) sustentam que a expedição tenha trazido algum sensível progresso às ciências naturais. Alguns alegam que os materiais conservados em São Petersburgo ainda têm 
grande valor potencial para eventuais estudos sobre a evolução (ou depauperação) da fauna brasileira. A hipótese é remota. O problema das potencialidades da expedição pode, porém, mesmo frente à magreza da publicação científica, ser até certo ponto analisado com base nas aquarelas e desenhos dos álbuns de 1988.

A qualidade e a quantidade das ilustrações zoológicas e botânicas indicam que Langsdorff pretendia publicar pelo menos um livro sobre a história natural da viagem. Os três desenhistas ilustraram 156 espécies de vertebrados, uma quantidade apreciável. Como não existe inventário do material de Langsdorff, publico (Tabela 1) a lista dos álbuns. Dessas 156 espécies, 140 podem ser identificadas sem hesitação. Aceitando (com duas exceções estatisticamente insignificantes) as identificações dos álbuns, fica possível verificar que importância teriam tido as coleções, no campo da faunística, se adequadamente estudadas.

Das 140 espécies identificáveis, 100 já haviam sido anteriormente descritas. Assim teria tido Langsdorff em mãos um máximo de 40 espécies novas de vertebrados, quase $30 \%$ das identificáveis, uma proporção normal para a época.

Pode-se tirar mais alguma informação do desdobramento desses dados. A Tabela 2 mostra que, como de costume, a contribuição dos anfíbios é mínima. Estavam esperando o lampião de querosene para começar a comparecer.

Verifica-se também como estava relativamente adiantada a sistemática de aves: $92 \%$ das espécies ilustradas já não eram novas. Nota-se entre elas a ausência de pequenos passeriformes: possivelmente não oferecessem atrativos pictóricos (pouco provável, há espécies lindas) ou fossem de mais difícil coleta e preparação.

Os mamíferos também já estavam relativamente bem conhecidos na época: $83 \%$ das espécies já eram descritas. Não há diferença estatística com relação às aves $\left(\chi^{2}=.524\right.$ para 1 grau de liberdade, probabilidade cerca de .50).

No caso dos peixes fluviais (só 4 espécies marinhas comuns são ilustradas, por Rugendas), as proporções são inversas: dois terços das espécies ainda eram desconhecidos da ciência. A diferença entre peixes de um lado e mamíferos e aves, do outro, é altamente significante $\left(\chi^{2}=40.777\right.$ para 2 graus de liberdade, probabilidade menor que .001).

Quanto às localidades, as espécies assim se distribuíam: bacia do Prata, 36 (Alto Paraná, 20, Alto Paraguai, 16), bacia do Amazonas (Tapajós), 9. Uma distribuição das mais promissoras, pois a ictiologia da alta bacia do Prata era desconhecida na época. Vemos assim que, pelo menos nos peixes, teria tido Langsdorff, se ajudado pela sorte, uma boa oportunidade de contribuir para o conhecimento da fauna brasileira.

\subsubsection{Conclusão}

A contribuição de Langsdorff ao conhecimento da fauna brasileira não está no nível da dos demais zoólogos aqui discutidos. Amadorismo e má sorte conspiraram para que a aventura quase nada representasse zoologicamente. Uma interessante lição colateral que se tira é que coleções têm seu tempo de maturação; ultrapassado este, o valor decai e acaba por desaparecer. A coleção ictiológica de Langsdorff, estudada no tempo certo, poderia ter sido valiosa. Hoje não é mais; nem valor histórico tem. Há indícios de que a coleção de mamíferos também pudesse ter tido algum interesse. Está igualmente ultrapassada.

Ménétriès cita localidades exatas anteriores à expedição; Brandt não. Qual era a prática da expedição ficamos sem saber, e esse é um elemento importante na avaliação das potencialidades, especialmente tendo em vista os dados geográficos de Spix, de Wied e de Castelnau.

Não sabemos o tamanho da coleção. Temos apenas uma lista dos exemplares desenhados, e não há informação sobre o destino desses exemplares após a coleta (coleção, panela ou volta ao rio), nem sobre que porcentagem da pesca para fins de coleção eles representavam. Uma coisa, porém, sabemos: por maior que seja o número de exemplares em São Petersburgo (e não tem como ser grande), a coleção remanescente não passa hoje de uma curiosidade científica. 


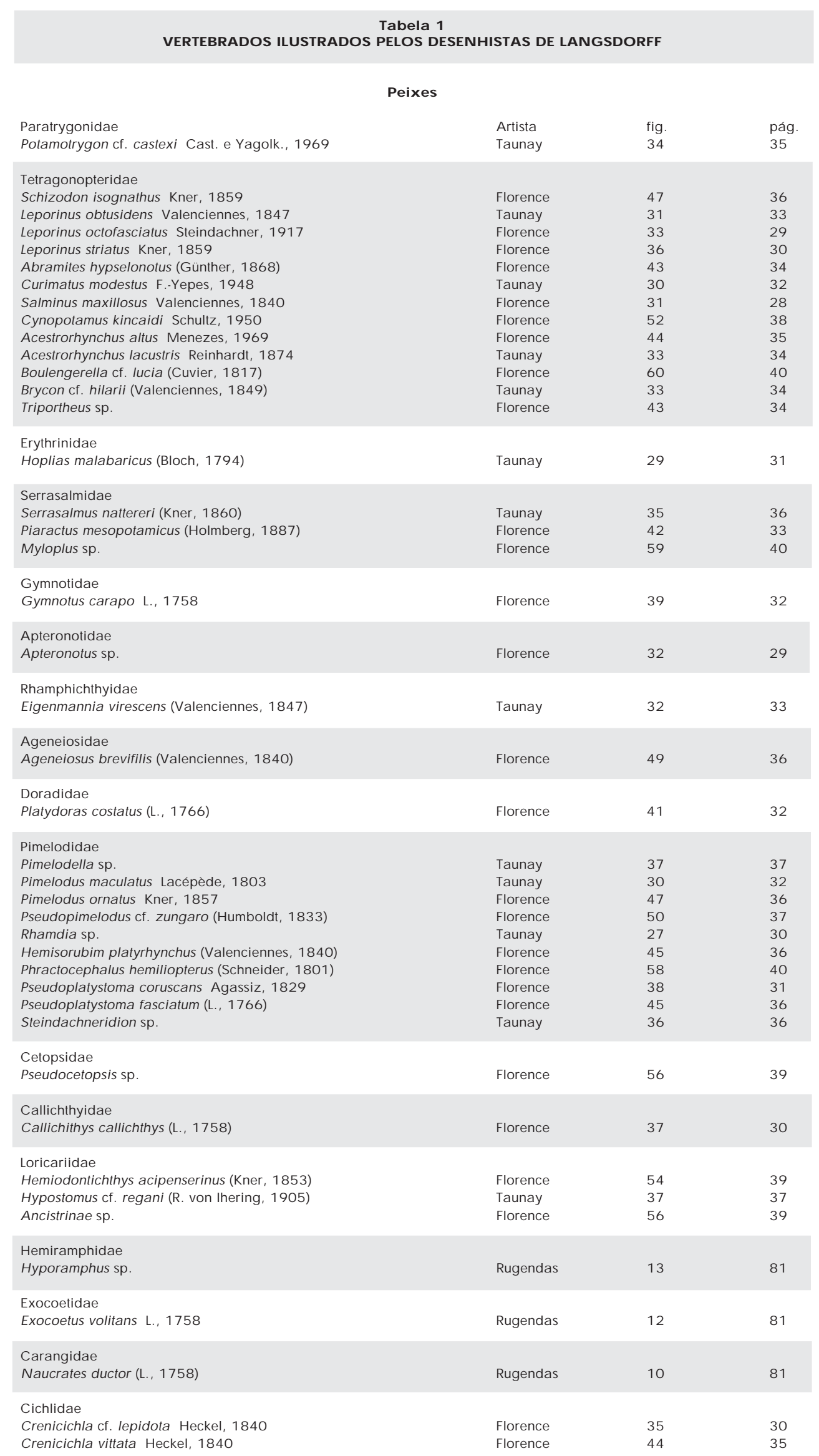




\begin{tabular}{|c|c|c|c|}
\hline Crenicichla sp. & Florence & 53 & 38 \\
\hline Cichlidae indeterminado & Florence & 34 & 30 \\
\hline $\begin{array}{l}\text { Diodontidae } \\
\text { Chilomycterus spinosus (L., 1758) }\end{array}$ & Rugendas & 11 & 81 \\
\hline \multicolumn{4}{|c|}{ Anfíbios } \\
\hline $\begin{array}{l}\text { Bufonidae } \\
\text { Bufo ocellatus G ünther, } 1859\end{array}$ & Florence & 62 & 42 \\
\hline $\begin{array}{l}\text { Leptodactylidae } \\
\text { Proceratophrys boiei (W ied, 1825) }\end{array}$ & Rugendas & 14 & 82 \\
\hline $\begin{array}{l}\text { Ceciliidae } \\
\text { Siphonops annulatus (Mikan, 1820) }\end{array}$ & Florence & 69 & 45 \\
\hline
\end{tabular}

Répteis

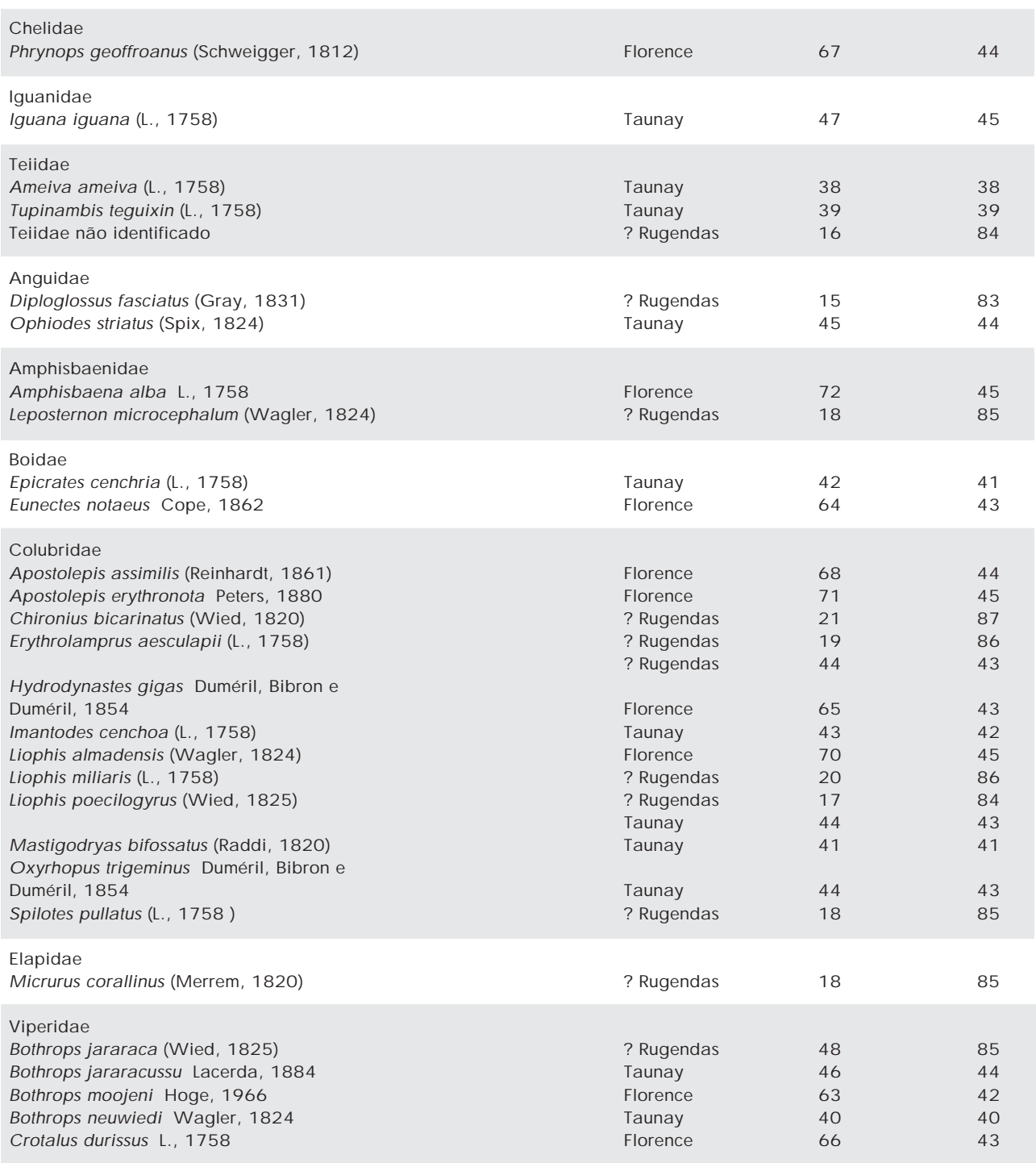

Aves

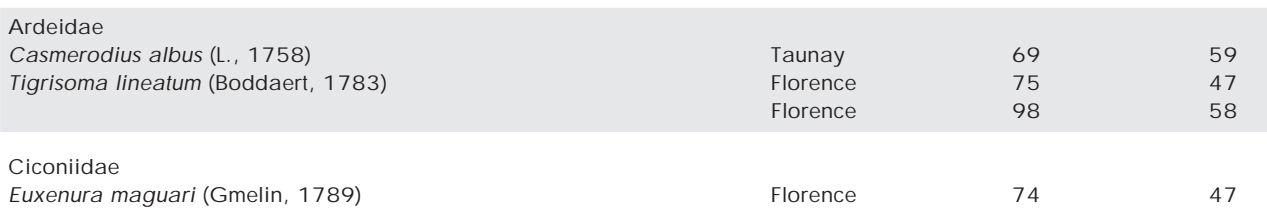




\begin{tabular}{|c|c|c|c|}
\hline $\begin{array}{l}\text { Threskiornithidae } \\
\text { Phimosus infusca tus (Lichtenstein, 1823) }\end{array}$ & Florence & 86 & 52 \\
\hline $\begin{array}{l}\text { A nhimidae } \\
\text { A nhima cornuta (L., 1758) } \\
\text { Chauna torquata (O ken, 1816) }\end{array}$ & $\begin{array}{l}\text { Taunay } \\
\text { Florence }\end{array}$ & $\begin{array}{l}78 \\
85\end{array}$ & $\begin{array}{l}64 \\
51\end{array}$ \\
\hline $\begin{array}{l}\text { A natidae } \\
\text { A mazonetta brasiliensis (G melin, 1789) } \\
\text { Cairina moschata (L., 1758) }\end{array}$ & $\begin{array}{l}\text { Taunay } \\
\text { Florence }\end{array}$ & $\begin{array}{l}64 \\
76\end{array}$ & $\begin{array}{l}55 \\
48\end{array}$ \\
\hline $\begin{array}{l}\text { Cathartidae } \\
\text { Sarcoramphus papa (L., 1758) }\end{array}$ & Taunay & $\begin{array}{l}23 \\
77\end{array}$ & $\begin{array}{l}27 \\
63\end{array}$ \\
\hline $\begin{array}{l}\text { Accipitridae } \\
\text { Chondrohierax uncinatus (Temminck, 1822) } \\
\text { Gampsonyx swainsonii (Vigors, 1825) } \\
\text { Rosthramus sociabilis (Vieillot, 1817) }\end{array}$ & $\begin{array}{l}\text { Florence } \\
\text { Florence } \\
\text { Taunay }\end{array}$ & $\begin{array}{l}88 \\
89 \\
96 \\
62\end{array}$ & $\begin{array}{l}53 \\
53 \\
57 \\
53\end{array}$ \\
\hline $\begin{array}{l}\text { Momotidae } \\
\text { Momotus momota (L., 1766) }\end{array}$ & $\begin{array}{l}\text { Florence } \\
\text { Florence }\end{array}$ & $\begin{array}{l}24 \\
77\end{array}$ & $\begin{array}{l}25 \\
49\end{array}$ \\
\hline $\begin{array}{l}\text { Bucconidae } \\
\text { Nystalus maculatus (G melin, 1788) }\end{array}$ & Florence & 24 & 25 \\
\hline $\begin{array}{l}\text { Ramphastidae } \\
\text { Pteronotus castanotis Gould, } 1833 \\
\text { Ramphastos toco P. L. S. M üller, } 1776 \\
\begin{array}{l}\text { Ramphastos tucanus L., } 1758\end{array}\end{array}$ & $\begin{array}{l}\text { Taunay } \\
\text { Taunay } \\
\text { Taunay } \\
\text { Florence }\end{array}$ & $\begin{array}{l}70 \\
68 \\
76 \\
99\end{array}$ & $\begin{array}{l}59 \\
58 \\
62 \\
59\end{array}$ \\
\hline $\begin{array}{l}\text { Picidae } \\
\text { Dryocopus lineatus (L., 1766) } \\
\text { M elanerpes cruentatus (Boddaert, 1783) }\end{array}$ & $\begin{array}{l}\text { Taunay } \\
\text { Taunay }\end{array}$ & $\begin{array}{l}59 \\
74\end{array}$ & $\begin{array}{l}52 \\
60\end{array}$ \\
\hline $\begin{array}{l}\text { Furna riidae } \\
\text { Furnarius rufus (G melin, 1788) } \\
\text { Schoeniophylax phryganophila (Vieillot, 1817) }\end{array}$ & $\begin{array}{l}\text { Florence } \\
\text { Florence }\end{array}$ & $\begin{array}{l}84 \\
87\end{array}$ & $\begin{array}{l}50 \\
52\end{array}$ \\
\hline $\begin{array}{l}\text { Formicariidae } \\
\text { Formicivorus colma Boddaert, } 1783\end{array}$ & Taunay & 48 & 46 \\
\hline $\begin{array}{l}\text { Rhinocryptidae } \\
\text { Melanopareia torquata (W ied, 1831) }\end{array}$ & $\begin{array}{l}\text { Taunay } \\
\text { Taunay }\end{array}$ & $\begin{array}{l}72 \\
79\end{array}$ & $\begin{array}{l}59 \\
65\end{array}$ \\
\hline $\begin{array}{l}\text { Falconidae } \\
\text { Herpetotheres cachinnans (L., 1758) } \\
\text { Milvago chimachima (Vieillot, 1816) } \\
\text { Polyborus plancus (M üller, 1777) }\end{array}$ & $\begin{array}{l}\text { Florence } \\
\text { Taunay } \\
\text { Taunay }\end{array}$ & $\begin{array}{l}94 \\
60 \\
55\end{array}$ & $\begin{array}{l}55 \\
53 \\
50\end{array}$ \\
\hline $\begin{array}{l}\text { Cracidae } \\
\text { Ortalis canicollis (W agler, 1830) } \\
\text { Penelope ochrogaster Pelzeln, 1870 } \\
\text { Penelope superciliaris Temminck, } 1815 \\
\text { Pipile grayi (Pelzeln, 1879) }\end{array}$ & $\begin{array}{l}\text { Florence } \\
\text { Florence } \\
\text { Taunay } \\
\text { Florence }\end{array}$ & $\begin{array}{l}81 \\
82 \\
56 \\
79\end{array}$ & $\begin{array}{l}50 \\
50 \\
50 \\
49\end{array}$ \\
\hline $\begin{array}{l}\text { Phasianidae } \\
\text { Odontophorus capueira (Spix, 1825) }\end{array}$ & Taunay & 56 & 50 \\
\hline $\begin{array}{l}\text { Rallidae } \\
\text { Micropygia schomburgkii (Schomburgk, 1848) } \\
\text { Porphyrula martinica (L., 1758) }\end{array}$ & $\begin{array}{l}\text { Taunay } \\
\text { Taunay } \\
\text { Taunay }\end{array}$ & $\begin{array}{l}71 \\
79 \\
61\end{array}$ & $\begin{array}{l}59 \\
85 \\
53\end{array}$ \\
\hline $\begin{array}{l}\text { Heliornithidae } \\
\text { Heliornis fulica (Boddaert, 1780) }\end{array}$ & Florence & 80 & 49 \\
\hline $\begin{array}{l}\text { Charadriidae } \\
\text { Vanellus chilensis (M olina, 1782) }\end{array}$ & Taunay & 63 & 54 \\
\hline $\begin{array}{l}\text { Rynchopidae } \\
\text { Rynchops nigra L., } 1758\end{array}$ & $\begin{array}{l}\text { Florence } \\
\text { Florence }\end{array}$ & $\begin{array}{l}73 \\
97\end{array}$ & $\begin{array}{l}46 \\
58\end{array}$ \\
\hline $\begin{array}{l}\text { Columbidae } \\
\text { Columba speciosa G melin, } 1789 \\
\text { Uropelia campestris (Spix, 1825) }\end{array}$ & $\begin{array}{l}\text { Florence } \\
\text { Florence }\end{array}$ & $\begin{array}{l}93 \\
95\end{array}$ & $\begin{array}{l}54 \\
56\end{array}$ \\
\hline
\end{tabular}




\begin{tabular}{|c|c|c|c|}
\hline Psittacidae & & & \\
\hline A nodorhynchus hyacinthinus (Latham, 1790) & Florence & 83 & 50 \\
\hline Brotogeris sp. & Taunay & 65 & 66 \\
\hline Pionus maximiliani (Kuhl, 1820) & Florence & 78 & 49 \\
\hline Tytonidae & & & \\
\hline Tyto alba (Scopoli, 1769) & Florence & 90 & 54 \\
\hline & Taunay & 67 & 57 \\
\hline Strigidae & & & \\
\hline O tus choliba (Vieillot, 1817) & Taunay & 57 & 51 \\
\hline Speotyto cunicularia (M olina, 1782) & Taunay & 58 & 51 \\
\hline Trochilidae & & & \\
\hline Lophornis magnifica (Vieillot, 1817) & Taunay & 54 & 49 \\
\hline Alcedinidae & & & \\
\hline Chloroceryle inda (L., 1766) & Florence & 91 & 54 \\
\hline Cotingidae & & & \\
\hline Cephalopterus ornatus Et. G eoffroy, 1809 & & & \\
\hline Procnias nudicollis (Vieillot, 1817) & Taunay & 53 & 49 \\
\hline Tyrannidae & & & \\
\hline Pyrocephalus rubinus (Boddaert, 1783) & Taunay & 52 & 49 \\
\hline Thraupidae & & & \\
\hline Stephanophorus diadematus (Temminck, 1823) & Taunay & 49 & 47 \\
\hline Tangara peruviana (Desmarest, 1806) & Taunay & 50 & 48 \\
\hline & & & \\
\hline Didelphidae & & & \\
\hline Caluromys philander (L., 1758) & Rugendas & 23 & 89 \\
\hline Chironectes minimus (Zimmermann, 1780) & Rugendas & 22 & 88 \\
\hline Didelphis albiventris Lund, 1840 & Taunay & 89 & 72 \\
\hline Didelphis a urita W ied, 1826 & ? Rugendas & 28 & 93 \\
\hline G racilinanus microtarsus (W agner, 1842) & Taunay & 82 & 67 \\
\hline Monodelphis domestica (W agner, 1842) & Florence & 102 & 60 \\
\hline Philander opossum (L., 1758) & Taunay & 90 & 73 \\
\hline Dasypodidae & & & \\
\hline Cabassous ta touay (Desmarest, 1804 ) & Taunay & 86 & 70 \\
\hline Dasypus novemcinctus L., 1758 & ? Rugendas & 24 & 90 \\
\hline Phyllostomidae & & & \\
\hline A rtibeus lituratus (0 Ifers, 1818) & Florence & 103 & 61 \\
\hline Chiroderma doriae Thomas, 1891 & ? Rugendas & 29 & 95 \\
\hline Platyrrhinus linea tus (Et. G eoffroy, 1810) & Taunay & 83 & 68 \\
\hline Callithrichidae & & & \\
\hline Callithrix argentata (L., 1771) & Taunay & 91 & 75 \\
\hline Callithrix a urita (Et. G eoffroy, 1812) & Rugendas & 9 & 79 \\
\hline & Rugendas & 32 & 96 \\
\hline Callithrix geoffroyi (Humboldt, 1812) & Rugendas & 33 & 97 \\
\hline Cebidae & & & \\
\hline A louatta fusca (Et. G eoffroy, 1812) & Taunay & 87 & 71 \\
\hline & Taunay & 88 & 71 \\
\hline Cebus albifrons (Humboldt, 1812) & Taunay & 92 & 75 \\
\hline Canidae & & & \\
\hline Cerdocyon thous (L., 1766) & Florence & 104 & 61 \\
\hline Felidae & & & \\
\hline Panthera onca (L, 1758) & Florence & 101 & 60 \\
\hline Procyonidae & & & \\
\hline & & & \\
\hline Cervidae & & & \\
\hline Mazama sp. & Taunay & 84 & 69 \\
\hline O zotocerus bezoarticus (L., 1758 ) & Florence & 100 & 60 \\
\hline Dasyproctidae & & & \\
\hline Dasyprocta azarae Lichtenstein, 1823 & Taunay & 81 & 67 \\
\hline Echimyidae & & & \\
\hline Euryzygomatomys spinosus (G. Fischer, 1814) & Taunay & 85 & 69 \\
\hline Leporidae & & & \\
\hline Sylvilagus brasiliensis (L., 1758) & Taunay & 80 & 67 \\
\hline
\end{tabular}




\begin{tabular}{|c|c|c|c|}
\hline \multicolumn{4}{|c|}{$\begin{array}{c}\text { Tabela } 2 \\
\text { ESPÉCIES IDENTIFICÁVEIS DE VERTEBRADOS REPRESENTADAS NOS ÁLBUNS DE LANGSDORFF: } \\
\text { ÉPOCA DE DESCRIÇÃO }\end{array}$} \\
\hline & Antes de 1830 & Depois de 1830 & \\
\hline Peixes fluviais & $9(28.1 \%)$ & $23(71.9 \%)$ & 32 \\
\hline Anfíbio & 2 & 1 & 3 \\
\hline Répteis & $20(71.4)$ & $8(26.6)$ & 28 \\
\hline Aves & $46(92.0)$ & $4(8.0)$ & 50 \\
\hline \multirow[t]{2}{*}{ M a míferos } & $20(83.3)$ & $4(16.7)$ & 24 \\
\hline & $97(70.8)$ & $40(29.2)$ & 137 \\
\hline
\end{tabular}

\subsection{Agassiz}

O encontro de Louis Agassiz e D. Pedro II foi uma convergência: um imperador que amava a intimidade dos sábios, e um sábio que amava a intimidade dos imperadores (pelo menos, dos ricos).

Agassiz, suíço-francês, começou a vida como geólogo, especificamente como glaciologista: ganhou rapidamente reputação por estudos pioneiros sobre as glaciações alpinas. Ainda muito jovem fez os peixes da expedição bávara, com o brilho que se sabe. A seguir publicou, entre 1833 e 1843, um tratado fundamental sobre peixes fósseis. Em 1850 emigrou para os Estados Unidos, onde fundou, na Universidade de Harvard, o Museum of Comparative Zoology (MCZ) que, apesar do nome sem sentido, foi e é uma instituição muito importante.

Agassiz era um conferencista abundante e apreciado. Tinha vida social intensa e mantinha relações pessoais com os grandes da política e, especialmente, das finanças. Desde o tempo em que, muito jovem, com seus 20 anos, estudara a coleção de Spix, acalentava o sonho de vir ao Brasil fazer pesquisa ictiológica de primeira mão. Acabou por montar uma expedição, custeada pelo milionário Nathaniel Thayer (o nome oficial era "Thayer Expedition to Brazil") e contando com entusiástico endosso de D. Pedro II. Veio em 1865.

Trouxe consigo um grupo de assistentes jovens e ainda inexperientes. (Alguns saíram para a fama, como o grande geólogo Frederick C. Hartt; os demais tiveram desempenho menor.) Com a intenção de cobrir a maior extensão territorial possível, dividiu sua equipe em subgrupos e distribuiu-os pelo país (Dick, 1977). Ficaram no campo até meados de 1866 , cerca de 14 meses ao todo.

O grosso das coleções foi conseguido na Amazônia, com total preponderância dos peixes, único grupo a que Agassiz se dedicou. Não se coletaram aves nem mamíferos: o preparador da expedição era fraco, os assistentes tinham tarefas e interesses próprios. Não havia no grupo um botânico, e não há praticamente notas ecológicas, apenas observações casuais de Agassiz, que via por todo lado vestígios de recentes glaciações (um dos erros mais egrégios da pesquisa no Brasil).

A meu ver, nunca zoólogo nenhum teve as condições de trabalho de que gozou Agassiz. Previamente avisados pela corte, os grandes fazendeiros faziam construir tanques e estocá-los com os peixes da região. Hospedavam a expedição. Agassiz escolhia os exemplares e seu artista, James Burkhardt, desenhava-os vivos. Essas aquarelas inéditas, da melhor qualidade, adornam hoje as paredes da diretoria do MCZ.

Na Amazônia, onde não havia fazendeiros ricos desejosos de agradar o imperador, teve Agassiz o concurso de um extraordinário oficial brasileiro, o major de engenheiros João Martins da Silva Coutinho. Vaqueano, pois tinha desempenhado missões militares na Amazônia (Garcia, 1922, p. 897), experiente, fino, dedicado, era um gerente ideal e companheiro de viagem ainda melhor. Os Agassiz referem-se a ele na narrativa da viagem com muito carinho.

Uma digressão. A narrativa é assinada pelo casal (Agassiz e Agassiz, 1868), mas foi 


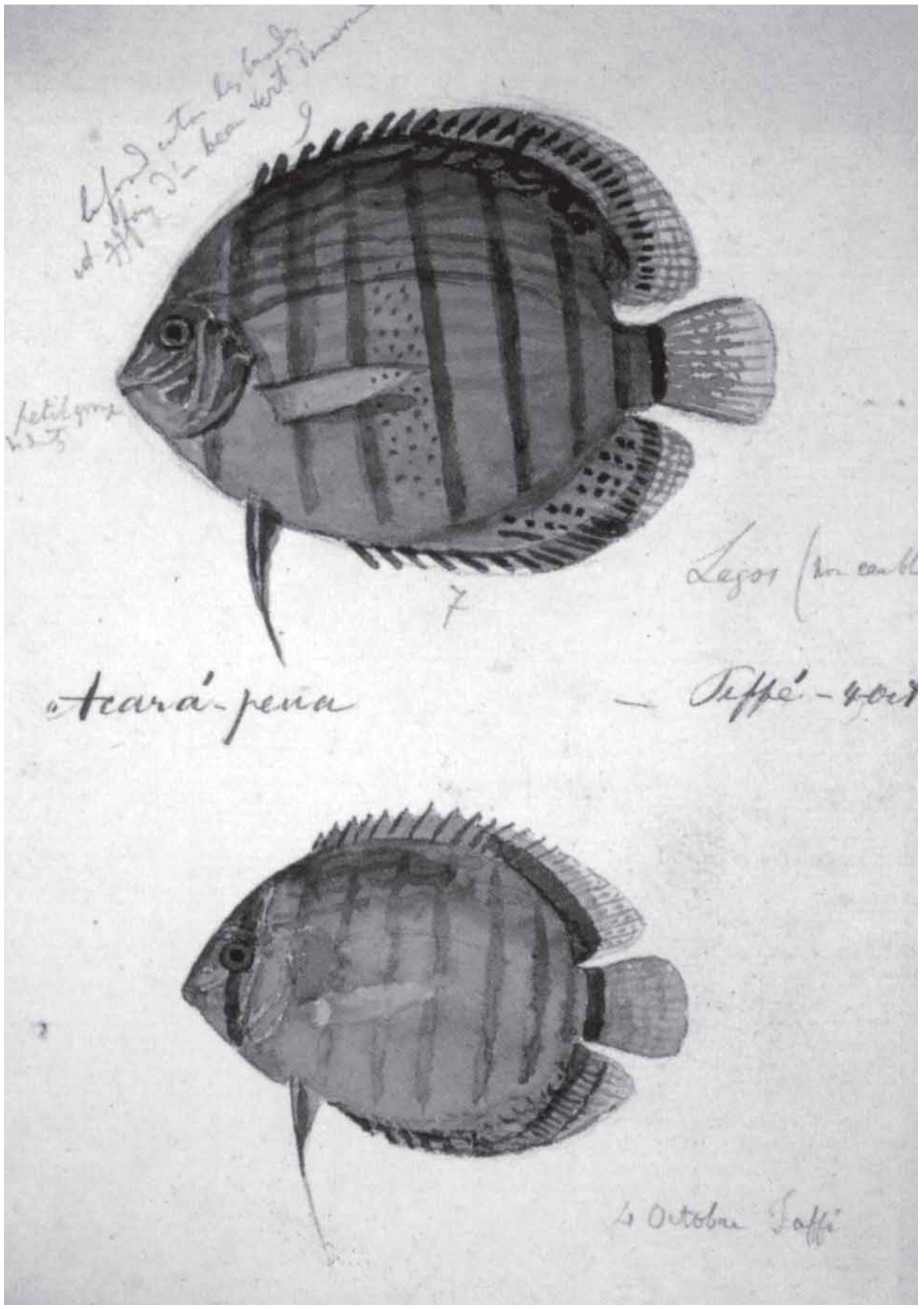




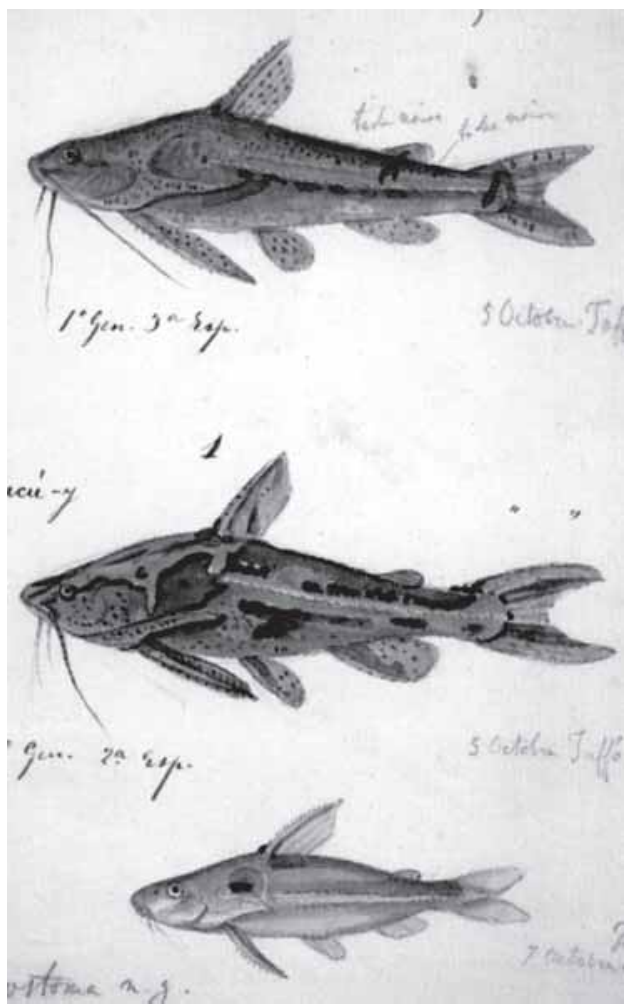

obviamente escrita pela mulher, Elisabeth Cary Agassiz, intelectual de seu próprio direito, fundadora do famoso e pioneiro Radcliffe College para moças, hoje fundido com a Universidade de Harvard. É uma narrativa clara, singela, simpática, mas também algo turística e muito convencional. É um estilo que não satisfaz o biólogo: quer-se algo com mais carne e sangue, e cheiro de chão. Por isso havia entre os zoólogos brasileiros um grande desejo de descobrir o "baú" do major Coutinho - seu arquivo pessoal, provavelmente contendo diários ou notas de campo, que se previam francos e interessantes.

Na década de 80 o baú foi descoberto, e a família, generosamente, permitiu a publicação do inventário (ver, na bibliografia, Inventário...). Foi uma terrível decepção. Não havia uma única nota sobre a expedição; em vez, farto material sobre estradas de ferro, aparentemente uma paixão do major. A Amazônia fora apenas "missão cumprida".

Como dito, os assistentes de Agassiz eram inexperientes - aliás, ele também era. As coleções, por motivos que nunca me foram explicados, foram recebidas e desempacotadas no museu, em Cambridge, Massachusetts, por um grupo de estudantes de Teologia. Diz a tradição oral no MCZ que nessa ocasião foram cometidas grandes barbaridades quanto à rotulagem dos exemplares.

Incorporada à seção de Ictiologia do MCZ, a coleção nunca foi estudada como um todo. Apenas uso eventual, tardio e pouco, foi feito de seus exemplares (por exemplo, Garman, 1913; Eigenmann, 1917). Na verdade, só muito recentemente o material recebeu curadoria adequada. Quando eu era aluno de pós-graduação no MCZ, o diretor do museu e meu orientador de tese, dr. A. S. Romer, contratou-me para dar um primeiro trato às localidades de Agassiz. Fiquei horrorizado, mas também fascinado. Havia, por exemplo, e entre muitos, um registro "Sarruarruhaia"; alguém escreveu "samambaia" com caligrafia angulosa, e o seminarista interpretou.

Como as coleções de Langsdorff, não tendo sido objeto de um estudo firme, que the marcasse a personalidade, a coleção de peixes de Agassiz tem hoje o mesmo valor que qualquer material avulso daquele tempo. Das regiões visitadas existem agora coleções bem preparadas e bem documentadas. A "Thayer Expedition”, apesar de Agassiz e de D. Pedro II, perdeu a vez na história.

\section{CONCLUSÃO}

A extensão e a duração das viagens dos primeiros naturalistas, compensando as deficiências técnicas da época, resultaram em uma sedimentação relativamente rápida do conhecimento da fauna brasileira. Por volta do terceiro quarto do século XIX os vertebrados do Brasil estavam melhor cadastrados do que, por exemplo, os dos Estados Unidos. A importância dos viajantes para a Zoologia em nível global foi das maiores.

Esse conhecimento não trouxe, porém, contribuição direta ao país. Não havia sequer germe de história natural, e esses materiais carreados para fora saíram da circulação cultural do Brasil. A zoologia brasileira veio a estabelecer-se no começo do século XX, fundada nos "Catálogos do Museu Britânico" que devidamente incorporavam a contribuição dos viajantes, diluída, porém, no tratamento catalográfico.
Jacques B urkhardt,

"Peixes

B rasileiros", aquarelas sobre

papel(1868),

M useum of

Comparative

Z oology, H arvard

University,

Cambridge 


\section{BIBLIOGRAFIA}

AB'SÁBER, A. N. "Os Domínios Morfoclimáticos na América do Sul. Primeira Aproximação”, in Geomorfologia (Inst. Geogr. Univ. S. Paulo), 52, 1977.

AGASSIZ, L. Ver SPIX, J. B. von, Selecta genera et species Piscium quos..., 1829.

- e AGASSIZ, E. C. A Journey in Brazil. Boston, Ticknor \& Fields, 1868, x + 540 p.

ALBERTIN, P. J. "Arte e Ciência no Brasil Holandês - Theatri Rerum Naturalium Brasiliae: um Estudo dos Desenhos", in Rev. Brasil. Zool., 3 (5), 1985, pp. 249-326.

ALLEN, J. A. "On the Maximilian Types of South American Birds in the American Museum of Natural History", in Bull. Amer. Mus. Nat. Hist., 2, 1889, pp. 209-76.

AMARAL, A. "Maximiliano, Príncipe de Wied", in Bol. Mus. Nac. Rio de Janeiro, 7 (3), 1931, pp. 187-210.

APPEL, T. A. The Cuvier-Geoffroy Debate. French Biology in the Decades before Darwin. New York and Oxford, Oxford University Press, 1987, (i) + 304 p.

AVILA-PIRES, F. D. "The Type Specimens of Brazilian Mammals Collected by Prince Maximilian zu Wied", in Amer. Mus. Novit., 2209, 1965, p. 121.

BALDUS, H. "Maximiliano, Príncipe de Wied-Neuwied", in Rev. Arq. Municip. S. Paulo, 74, 1941, pp. 283-91.

BETHENCOURT FERREIRA, J. “Trabalhos de Erpetologia do Museu Bocage. I e II.

Emydosaurios e Tartarugas da Colecção Antiga, Provenientes da Exploração do Dr. Alexandre Rodrigues Ferreira no Norte do Brasil (1783-1793)", in J. Sci. Mat. Fis. Nat. Acad. Sci. Lisboa, (3) 14, 1923, pp. 1-15, pls.

BOESEMAN, M. "The Vicissitudes and Dispersal of Albertus Seba's Zoological Specimens", in Zool. Meded. Leiden, 44 (13), 1970, pp. 177-206, pls.

BRITISH MUSEUM (Natural History). Catalogue of the Books, Manuscripts, Maps and Drawings in the British Museum (Natural History). Vol. II, E - K, pp. 501-1038. London, Trustees of the British Museum, 1904.

BOKERMANN, W. C. A. "Atualização do Itinerário da Viagem do Príncipe de Wied ao Brasil (1815-1817)", in Arq. Zool., S. Paulo, 10 (3), 1957, pp. 209-51.

BRANDT, J. F. "Mammalium Rodentium Exoticorum Novorum vel Minus Rite Cognitorum Musei Academici Zoologici Descriptio et Icones", in Mém. Acad. Sci. St. Petersburg, (6) 3 (2), 1835, pp. 357-442, pls.

CABRERA, A. "Catálogo de Mamíferos de América del Sur", in Rev. Mus. Arg. Ci. Nat.

"Bernardino Rivadavia", 4 (1), 1958, iv + 307 p. (1957).

CARVALHO, C. T. "Comentários sobre os Mamíferos Descritos e Figurados por Alexandre

Rodrigues Ferreira em 1790”, in Arq. Zool. S. Paulo, 12, 1965, pp. 7-70.

CARVALHO, J. Silva. Ver SILVA CARVALHO, J.

CASCUDO, L. C. O Príncipe Maximiliano de Wied-Neuwied no Brasil. Rio de Janeiro, Kosmos, 1977, 179 p.

CASTELNAU, F. de. Expédition dans les parties centrales de l'Amérique du Sud, de Rio de Janeiro a Lima, et de Lima au Para; exécutée par ordre du gouvernement français pendant les années 1843 a 1847 sous la direction de Francis de Castelnau. Histoire du voyage. 6 vols. (vols. 14 sobre o Brasil). Paris, P. Bertrand, 1850-51.

. Expedição às Regiões Centrais da América do Sul. 2 volumes. Tradução de Olivério M. de Oliveira Pinto. São Paulo, Companhia Editora Nacional (Biblioteca Pedagógica Brasileira, Série 5a Brasiliana, pp. 266-7), 1949.

- Animaux nouveaux ou rares recueillis pendant l'expédition dans les parties centrales de l'Amérique du Sud, de Rio de Janeiro a Lima et de Lima au Para; exécutée par ordre du gouvernement français pendant les années 1843 a 1847, sous la direction du Comte Francis de Castelnau. Tome Premier. Paris, P. Bertrand, 1855-56.

-. Animaux Nouveaux ou Rares Recueillis Pendant l'Expédition... Tome Second. Paris, P. Bertrand, 1855-56.

_. "Poissons", in F. Castelnau, Animaux Nouveaux ou Rares... Tome second. Paris, P. Bertrand, 1855-56.

—. "Relatorio Dirigido ao Ministro de Instrucção Publica pelo Sr. Castelnau, Encarregado de uma Commissão na America Meridional”, in Rev. Trimens. Hist. Geogr., 7, 2ae edição, 1866, pp. 196-203.

CHROSTOWSKI, T. "Sur les Types d'Oiseaux Néotropicaux du Musée Zoologique de l'Académie des Sciences de Petrograd", in Ann. Zool. Mus. Polon. Hist. Nat., 1 (1), 1921, pp. 9-30.

CHUR, L. A. (coord.). A Expedição Científica de G. I. Langsdorff ao Brasil-1821-1829. 2ae edição. Tradução de M. P. Braga. Brasília, Fundação Pró-Memória, 1981, 230 p.

CORRÊA FILHO, V. Alexandre Rodrigues Ferreira. Vida e Obra do Grande Naturalista Brasileiro. São Paulo, Companhia Editora Nacional (Série 5ạ, Brasiliana, vol. 144), 1939, 231 + (1) p. DES MURS, O. "Oiseaux", in F. Castelnau, Animaux Nouveaux ou Rares... Tome Premier, 185556.

DEVILLE, E. “Description de quelques Mammifères et Oiseaux Nouveaux de l'Amérique 
Méridionale", in Rev. Mag. Zool., (2) 1, 1849, pp. 55-8.

"Note sur Quatre Espèces Nouvelles d'Oiseaux Provenant de l'Expédition de M. Castelnau; le Conurus weddellii, C. jugularis, C. Luciani et Cultrides Pucheranii”, in Rev. Mag. Zool. (2) 3, 1851, pp. 209-13.

. "Observations Faites en Amérique du Sud sur les Moeurs de Différentes Espèces d'Oiseaux-Mouches, Suivies de Quelques Notes Anatomiques et de Moeurs sur l'Hoazin, le Caurale et le Savacou", in Rev. Mag. Zool. (2) 4, 1852a, pp. 209-26.

- "Notice sur le Genre Dactylomys, et Établissement d'un Genre Nouveau, Lasiuromys, Provenant de l'Expédition de M. de Castelnau", in Rev. Mag. Zool. (2) 4, 1852b, pp. 353-61.

- "Description d'un Nouveaux Genre de Rongeurs sous le nom de Lasiuromys", in P. Gervais, "Mammifères" (F. Castelnau, Animaux Nouveaux ou Rares ..., Tome Premier), 1856, pp. 104-6.

— e DES MURS, O. "Notice sur le Barbu Orangé du Pérou (Capito Peruvianus); sur le Barbu de la Guyane (C. erythrocephalus) et sur une Variété Intermédiaire ou Espèce Nouvelle $(C$. amazonicus?)", in Rev. Mag. Zool. (2) 1, 1849a, pp. 161-76.

e DES MURS, O. "Note sur une Nouvelle Espèce de Couroucou (Trogon ramoniana), et sur le Trogon meridionalis", in Rev. Mag. Zool. (2) 1, 1849b, pp. 331-3.

e SCLATER, P. L. "Description d'une Nouvelle Espèce de Cotinga Provenant de

l'Expédition de MM. de Castelnau et Deville dans l'Amérique du Sud", in Rev. Mag. Zool. (2) 4, 1852 , pp. 226-7.

DICK, M. M. Stations of the Thayer Expedition to Brazil 1865-1866. Breviora 444, 1977, 37 p. DUMÉRIL, A. M. C.; BIBRON, G. e DUMÉRIL, A. Erpétologie Générale ou Histoire Naturelle Complète des Reptiles. Vol. 7 (2). Paris, Librairie Encyclopédique de Roret, 1854, pp. xxii + 7811536.

EIGENMANN, C. H. "The American Characidae", in Mem. Mus. Comp. Zool. 43 (1), 1917, 102 p., pls.

EXPEDIÇÃO LANGSDORFF AO BRASIL 1821-1829. Vol. 1, Aquarelas e Desenhos de Rugendas, 154 p.; Vol. 2, Aquarelas e Desenhos de Taunay, 159 p.; Vol. 3, Aquarelas e Desenhos de Florence, 134 p. Rio de Janeiro, Alumbramento, 1988.

FEBVRE, L. e MARTIN, H.-J. O Aparecimento do Livro (original francês L'Apparition du Livre). São Paulo, Editora Unesp-Hucitec, 1992, 572 p.

FERREIRA, Alexandre Rodrigues. Ver RODRIGUES FERREIRA, Alexandre.

FERREIRA, J. Bethencourt. Ver BETHENCOURT FERREIRA, J.

FITTKAU, E. J. "Johann Baptist Ritter von Spix - Sein Leben und wissenschaftliches Werk", in E. J. Fittkau (ed.), Festschrift zu Ehren von Dr. Johann Baptist Ritter von Spix. Spixiana Suppl., 9, 1983, $441 \mathrm{p}$.

FITZINGER, L. "Miscellen: Lepidosiren paradoxus", in Not. Gebiet. Natur- u. Heilkunde, 1084, 1836, p. 90.

FITZINGER, L. J. F. J. Vorläufiger Bericht ueber eine hoechst interessante Entdeckung Dr. Natterer's in Brasil. Isis von Oken 379-380, 1837.

FLORENCE, H. "Esboço da Viagem Feita pelo Sr. de Langsdorff no Interior do Brasil, desde Setembro de 1825 até Março de 1829. Escripto em Original Francez pelo 2o Desenhista da Commissão Scientifica ... Traduzido por Alfredo d'Escragnolle Taunay", in Rev. Trimens. Inst. Hist. Geogr. Ethnogr. Brasil, 38 (1), pp. 355-469; 38 (2), pp. 231-301; 39 (2), pp. 157-82, 1875-76. . "De Porto Feliz a Cuyabá (1826-1827). (Diário de Viagem de um Naturalista da Expedição do Barão de Langsdorff)", in Rev. Mus. Paulista, 16, 1929, pp. 881-991. Tradução do Visconde de Taunay.

. Viagem Fluvial do Tietê ao Amazonas, de 1825 a 1829. Tradução do Visconde de Taunay. São Paulo, Melhoramentos, 1941, xxxvi +218 p., pls.

FOWLER, H. W. "A List of the Fishes Known from the Coast of Brazil", in Arq. Zool. S. Paulo, 3 (6), 1941, pp. 115-84.

—. "Os Peixes de Água Doce do Brasil", in Arq. Zool. S. Paulo, 6, pp. 1-628; 9, pp. 1-400, 1948-54.

GARCIA, Rodolfo. "Historia das Explorações Scientificas", in Instituto Historico e Geographico Brasileiro, Diccionario Historico, Geographico e Ethnographico do Brasil (Commemorativo do Primeiro Centenario da Independencia). Introducção geral. Primeiro volume (Brasil), 1922, pp. 856-910.

GARMAN, S. "The Plagiostomia (Sharks, Skates, and Rays)", in Mem. Mus. Comp. Zool., 36, 1913, xiii + 515 p.

GEOFFROY SAINT-HILAIRE, E. "Mémoire sur les Singes à main Imparfaite ou les Atlèles", in Ann. Mus. Nat. Hist. Nat. Paris, 7, 1806, pp. 260-73.

- "Sur l'Accroissement des Collections des Mammifères et des Oiseaux du Muséum d'Histoire Naturelle", in Ann. Mus. Hist. Nat. Paris, 13, 1809a, pp. 87-8.

- "Description de deux Singes d'Amérique, sous les Noms d'Ateles arachnoides et d'Ateles marginatus", in Ann. Mus. Nat. Hist. Nat. Paris, 13, 1809b, pp. 89-97.

—. "Tableau des Quadrumanes ou des Animaux Composant le Premier Ordre de la Classe des 
Mammifères", in Ann. Mus. Nat. Hist. Nat. Paris, 19, 1812, pp. 85-122.

GEOFFROY SAINT-HILAIRE, I. "Note sur Plusieurs Espèces Nouvelles de Mammifères, de l'Ordre des Primates", in C. R. Acad. Sci. Paris, 31, 1850, pp. 873-6.

. "Note sur Plusieurs Espèces Nouvelles de Mammifères Primates", in Rev. Mag. Zool., (2)

3, 1851a, pp. 20-4.

. Muséum d'Histoire Naturelle de Paris. Catalogue Méthodique de la Collection des

Mammifères de la Collection des Oiseaux et des Collections annèxes. Première partie. -

Mammifères. Catalogue des Primates. Paris, Gide et Baudry, 1851b, vii + 96 p.

"Primates", in P. Gervais, Mammifères (F. Castelnau, Animaux Nouveaux ou Rares...

Tome Premier), 1855-56, pp. 1-25.

e DEVILLE, E. "Note sur huit Espèces Nouvelles de Singes Américains, Faisant Partie des

Collections de MM. de Castelnau et Émile Deville", in C. R. Acad. Sci. Paris, 27, 1848, pp. 497-9. GERVAIS, P. "Anatomie", in F. Castelnau, Animaux Nouveaux ou Rares..., Tome Premier, 1855$56 \mathrm{a}$.

"Mammifères", in F. Castelnau, Animaux Nouveaux ou Rares..., Tome Premier, 1855-56b. "Énumération des Principales Espèces de Mammifères Recueillis Pendant l'Expédition

Exécutée dans les Parties Centrales de l'Amérique du Sud", in P. Gervais, "Mammifères" (F. Castelnau, Animaux Nouveaux ou Rares..., Tome Premier), 1855-56c, pp. 107-16.

" "Description Ostéologique de l'Hoazin, du Kamichi, du Cariama et du Savacou, Suivie de Remarques sur les Affinités Naturelles des Oiseaux", in P. Gervais, "Anatomie" (F. Castelnau,

Animaux Nouveaux ou Rares..., Tome Premier), 1856a, pp. 65-92.

"Remarques Ostéologiques sur les Genres Brachyure et Callitriche de la Tribu des Singes Américains", in P. Gervais, "Anatomie" (F. Castelnau, Animaux Nouveaux ou Rares..., Tome Premier), 1856b, pp.93-5.

"Ostéologie de la tête du Vastrès et du Mylétès", in P. Gervais, "Anatomie" (F. Castelnau, Animaux Nouveaux ou Rares..., Tome Premier), 1856c, pp. 96-8.

"Documents Zoologiques pour Servir a la Monographie des Cheiroptères Sud-américains", in P. Gervais, "Mammifères" (F. Castelnau, Animaux Nouveaux ou Rares..., Tome Premier), 1856d, pp. $25-88$

. "Description des Trois Espèces de Dauphins qui Vivent dans la Région du Haut Amazone", in P. Gervais, "Mammifères" (F. Castelnau, Animaux Nouveaux ou Rares..., Tome Premier), 1856e, pp. 89-94.

"Sur quelques Points de l'Histoire Zoologique de Sarigues et plus Particulièrement sur leur Système Dentaire", in P. Gervais, "Mammifères" (F. Castelnau, Animaux Nouveaux ou Rares..., Tome Premier), 1856f, pp. 95-103.

GOELDI, E. A. Ensaio sobre o Dr. Alexandre R. Ferreira. Pará (Belém), Alfredo Silva, 1895, 109 p.

. Alexandre Rodrigues Ferreira. Brasília, Editora da Universidade de Brasília, 1982, 80 p. (Contém, além do texto da publicação de 1895, uma apresentação e bibliografias de e sobre Alexandre.)

GROVES, C. P. "Order Primates", in D. E. Wilson e D.-A. M. Reeder (eds.), Mammal Species of the World. A Taxonomic and Geographic Reference. 2nd ed. Washington and London, Smithsonian Institution Press, 1993, pp. 243-77.

GÜNTHER, A. C. L. G. An Introduction to the Study of Fishes. Edinburgh, Adam and Charles Black, 1880, xvi $+720 \mathrm{p}$

GUICHENOT, A. "Reptiles", in F. Castelnau, Animaux Nouveaux ou Rares..., Tome Second., 1855-56, 96 p., pls.

HARTMANN, T. "A Contribuição da Iconografia para o Conhecimento de Índios Brasileiros do Século XIX", in Coleção Museu Paulista, Série de Etnologia, 1, 1975, 229 p.

HECKEL, J. "Johann Natterer's neue Flussfische Brasiliens nach den Beobachtungen und Mittheilungen des Entdeckers (Erste Abteilung, die Labroiden)", in Ann. Wien. Mus. Naturg., 2, 1840, pp. 327-470, pls.

HELLMAYR, C. E. "Revision der Spix'schen Typen brasilianischer Vögel”, in Abh. kgl. bayer. Akad. Wiss., 22, 1906, pp. 561-726.

. "Catalogue of the Birds of the Americas and the Adjacent Islands in Field Museum of Natural History. Part III, Pteroptochidae - Conopophagidae - Formicariidae", in Field Mus. Nat. Hist. Publ., 223 (Zool. Ser., 13), 1924, viii + 369.

HOFFMANSEGG, J. C. v. "Beischreibung vier Affenartiger Thiere aus Brasilien", in Mag. Ges. Naturf. Fr. Berlin, 1807, pp. 83-104.

HOOGMOED, M. S. e GRUBER, U. "Spix and Wagler Type Specimens of Reptiles and Amphibians in the Natural History Musea in München (Germany) and Leiden (The Netherlands)", in E. J. Fittkau (ed.), Festschrift zu Ehren von Dr. Johann Baptist Ritter von Spix. Spixiana Suppl., 9, 1983, 441 p., pp. 319-415.

HUMBOLDT, A. "Sur les singes qui habitent les rives de l'Orénoque, du Cassiquiare et du Rio Negro", in A. Humboldt e A. Bonpland, Recueil d'Observations de Zoologie Faites dans l'Océan Atlantique, dans l'intérieur du Nouveau Continent et dans la Mer du Sud Pendant les Années 1799, 
1800, 1801, 1802 et 1803. Premier volume. Paris, F. Schoell; G. Dufour, 1812, viii+ 368p., pp. 30535.

INTERNATIONAL COMMISSION ON ZOOLOGICAL NOMENCLATURE. International Code of Zoological Nomenclature Adopted by the XX General Assembly of the International Union of Biological Sciences. International Trust for Zoological Nomenclature in Association with British Museum (Natural History). London, University of California Press, Berkeley and Los Angeles, $1985, \mathrm{xx}+338 \mathrm{p}$.

INVENTÁRIO ANALÍTICO DO ARQUIVO JOÃO MARTINS DA SILVA COUTINHO. Projeto Arquivo Permanente do Museu Paraense Emilio Goeldi 1. Brasilia, Conselho Nacional de Desenvolvimento Científico e Tecnológico, CNPq; Belém, Museu Paraense Emilio Goeldi, s.d., 148 p. KOMISSAROV, B. N. "A Expedição do Acadêmico G. I. Langsdorff e seus Artistas ao Brasil", in Expedição Langsdorff ao Brasil 1821-1829, 1988, pp. 11-36.

KOOPMAN, K. "Order Chiroptera", in D. E. Wilson and D.-A. M. Reeder (eds.), Mammals Species of the World, a Taxonomic and Geographic Reference. 2nd ed. Washington and London, Smithsonian Institution Press, 1993, pp. 137-241.

KRAFT, R. "Die von J. B. v. Spix beschriebenen neotropischen Primaten und Chiropteren. Verzeichniss der in der Zoologischen Staatsammlung München aufbewahrten Typus-exemplare", in E. J. Fittkau (ed.), Festschrift zu Ehren von Dr. Johann Baptist Ritter von Spix. Spixiana Suppl., 9, 1983, 441 p., pp. 429-41.

KUHL, H. Beiträge zur Zoologie und vergleichenden Anatomie. Frankfurt a. M., Hermann, 1820, $232+151 \mathrm{p}$.

LAWRENCE, M. A. e GENETT, M. E. "Conserving a Wied-Neuwied Mammal Type: an Archival Container", in Curator, 31, 1988, pp. 53-60.

LICHTENSTEIN, M. H. K. "Die Werke von Marcgrave und Piso ueber die Naturgeschichte Brasiliens erläutert aus den wieder aufgefunden Originalzeichnungen", in Abh. K. Akad. Wiss. Berlin, 1814-15 (1818), pp. 202-22; 1816-17 (1819), pp. 155-78; 1820-21 (1822), pp. 237-54, pp. 267-88; 1826, pp. 49-65.

$$
\text { Estudo Crítico dos Trabalhos de Marcgrave e Piso sobre a História Natural do Brasil à }
$$

Luz dos Desenhos Originais. São Paulo, Brasiliensia Documenta, 2, 1961, 306 p. (Inclui um ensaio bio-bibliográfico sobre Lichtenstein, o texto em alemão, uma tradução portuguesa e comentários por Olivério Pinto.)

LIMA, Américo Pires de. Ver PIRES DE LIMA, Américo.

LINNAEUS, Carl, depois Carl von Linné. Systema Naturae per Regna Tria Naturae... Tomus I. Editio Decima, reformata. Holmiae, Laurentii Salvii, 1758, 824 p. (Cura Societatis Zoologicae Germanicae iterum edita, 1894).

LINNÉ, Carl von. Systema Naturae per Regna Tria Naturae... Editio Duodecima, reformata. Tomus I. Holmiae, Laurentius Salvius, 1766.

LISBOA, frei Cristóvão de. História dos Animais e Árvores do Maranhão. Estudo e notas do dr. Jaime Walter. Lisboa, Arquivo Histórico Ultramarino e Centro de Estudos Históricos Ultramarinos, 1967, xii + $158+$ (4) p., 221 pls. (fac-similar).

LOTUFO-NETO, F. e GENTIL, V. "Alcoholism and Phobic Anxiety - a Clinical-demographic Comparison”, in Addiction, 89, 1994, pp. 447-53.

MARCGRAVE. G. Historia Naturalis Brasiliae. Auspicio et Beneficio Illustriss. I. Mauritii Com. Nassau... non tantum Plantae et Animalia, sed et Indigenarum morbi, ingenia et mores describuntur et iconibus supra quingentas illustrantur. Lugdun. Batavorum, apud Franciscus Hackium et Amstelodami apud Lud. Elzevirium, 1648, $293+$ (4) p.

MARCGRAVE, J. História Natural do Brasil. Tradução de mons. José Procopio de Magalhães. São Paulo, Museu Paulista (edição comemorativa do Centenário da Imprensa Oficial do Estado de São Paulo), 1942, iv + (7) + 293 + (4) + civ p. (Inclui escorço biográfico por A. d'E. Taunay; comentários por A. J. Sampaio (Botânica), J. P. Carvalho e P. Sawaya (Peixes); P. Sawaya (Crustáceos); O. M. O. Pinto (Aves); P. Sawaya (Mamíferos, Répteis e Anfíbios).

MARTIUS, C. F. P. von. Wörtersammlung Brasilianischer Sprachen. Glossaria Linguarum Brasiliensium. Glossários de Diversas Lingoas e Dialectos, que fallao os Indios no Imperio do Brazil. Leipzig, Fiedrich Fleischer, 1867, xxi + 548 p.

MENDES, João Ribeiro. "Instruções Relativas a Viagem Philosophica Effectuada pelo Naturalista Dr. Alexandre Rodrigues Ferreira, nos Anos de 1783-92”, in Rev. Soc. Brasil. Geogr., 53, 1946, pp. 46-52.

MÉNÉTRIÈS, E. "Monographie de la Famille des Myiotherinae où Sont Décrites les Espèces qui Ornent le Musée de l'Académie Impériale des Sciences", in Mém. Acad. Sci. St. Petersbourg, (6) 3 (2) , 1835, pp. 443-543.

MIKAN, J. C. Delectus Florae et Faunae Brasiliensis. Vienna, Ant. Strauss, 1820-25, 47 p., pls. MITTERMEIER, R. A., MEDEM, F. and RHODIN, A. J. "Vernacular Names of South American Turtles", in Soc. St. Amph. Rept. Herp. Circ., 9, 1980, 44 p.

MOREIRA NETO, C. A. "Introdução", in Alexandre Rodrigues Ferreira, Viagem Filosófica ao Rio Negro, 1983, pp. 13-42.

NATTERER, J. "Lepidosiren paradoxa, eine neue Gattung aus der Familie der fischaenlichen 
Reptilien”, in Ann. Naturhist. Mus. Wien, 2, 1837, pp. 165-70.

"Beitrag zur näheren Kenntniss der südamerikanischen Alligatoren nach gemeinschaftliche Untersuchungen mit L.J. Fizinger", in Ann. Naturhist. Mus. Wien., 2, 1840, pp. 313-24.

NEIVA, Arthur. Esboço Histórico sobre a Botanica e Zoologia no Brasil. De Gabriel Soares de Souza, 1587, a 7 de Setembro de 1922. São Paulo, Soc. Impressora Paulista, 1929, 143 p. ("Publicado em 7 de Setembro de 1922, no numero commemorativo da centenario da Independencia do 'O Estado de São Paulo"”.)

PAPAVERO, N. Essays on the History of Neotropical Dipterology, with Special Reference to Collectors (1750-1905). 2 vols. São Paulo, Museu de Zoologia, Universidade de São Paulo, 197173

PELZELN, A. von. Zur Ornithologie Brasiliens. Resultate von Johann Natterers Reisen in den Jahren 1817 bis 1835. Wien, A. Pichler's Witwe \& Sohn, 1868-70, lix + 462 p. "Itinerarium von Natterer's Reisen in Brasilien von 1817-1835, appendix", in Zur Ornithologie Brasiliends, Resultate von J. Natterers Reisen in den Jahren 1817-35. Wien, A. Pichler's Witwe \& Sohn, 1871, lix +462 p., pp. i-xx.

"Brasilische Säugethiere. Resultate von Johann Natterer's Reisen in den Jahren 1817 bis 1835", in Verh. zool.-bot. Ges. Wien, 33 (Suppl.), 1883, pp. 1-136.

PIETERS, F. F. J. M. "Notes on the Menagerie and Zoological Cabinet of Stadholder William V of Holland, Directed by Aernout Vosmaer", in J. Soc. Bibl. Nat. Hist., 9 (4), 1980, pp. 539-63.

PINTO, O. M. O. "Catálogo das Aves do Brasil e Lista dos Exemplares que as Representam no Museu Paulista. Primeira Parte, Aves não Passeriformes e Passeriformes não Oscines, Excluida a Fam. Tyrannidae e seguintes", in Rev. Mus. Paulista, 22, 1938, xviii + 566p. pp. $13-7$.

"Introdução", in Maximiliano, Príncipe de Wied-Neuwied, Viagem ao Brasil, Brasiliana,

- Catálogo das Aves do Brasil e Lista dos Exemplares Existentes na Coleção do Departamento de Zoologia. Segunda Parte, Ordem Passeriformes (continuação): Superfamília Tyrannoidea e Sub-Ordem Passeres. São Paulo, Departamento de Zoologia, Secretaria da Agricultura, 1944.

. "Súmula Histórica e Sistemática da Ornitologia de Minas Gerais", in Arq. Zool. S.Paulo, 8 (1), 1952, pp. 1-51

. A Ornitologia do Brasil através das Idades (Século XVI a Século XIX). São Paulo,

Brasiliensia Documenta, 13, 1979, 117 p.

PIRES DE LIMA, Américo. O Doutor Alexandre Rodrigues Ferreira. Lisboa, Agência Geral do Ultramar, 1953, $426 \mathrm{p}$.

PONTES, R. S. S. "Biographia dos Brasileiros Distinctos por Lettras, Armas, Virtudes, etc.", in Rev. Trimens. Hist. Geogr., 2 (2 ed.) , 1858, pp. 501-12. (Contém um "Additamento" de Manoel Maria José da Costa e Sá sobre o espólio literário de Alexandre.)

RADDI, G. "Di Alcune Specie Nuovi di Rettili e Piante Brasiliane", in Atti. Soc. Ital. Sci., Modena, 18,1820 , pp. 1-39, pls.

. "Continuazione della Descrizione dei Rettili Brasiliani Indicati nella Memoria Inserita nello Secondo Fascicolo delle Memorie di Fisica del Precedente Volume XVIII", in Atti Soc. Ital. Sci., Modena, 19, 1822, pp. 56-73.

RAMIREZ, E. S. As Relações entre a Áustria e o Brasil, 1815-1889. Tradução e notas de Américo Jacobina Lacombe. São Paulo, Companhia Editora Nacional (Brasiliana, vol. 337), 1968.

RATZEL, F. "Max Prinz von Wied-Neuwied", in Allg. Deutsche Biogr., 22, 1885, pp. 559-64.

REICHHOLF, J. H. "Der Bestand an Typenmaterial der ornithologischen Aufsammlungen von J. B. von Spix in der Zoologische Staatsammlung München", in E. J. Fittkau (ed.), Festschrift zu Ehren von Dr. Johann Baptist Ritter von Spix. Spixiana Suppl., 9, 1983, 441 p., pp. 417-23.

REINHARDT, J. "Bidrag til Kundskab om Fuglefaunaen i Brasiliens Campos. Anden Halvdeel”, in Vid. Medd. Naturhist. For. Kjöbenhavn 1870 (21-28), pp. 315-457.

ROCHA, L. Viajantes Estrangeiros no Espírito Santo. Brasília, Editora de Brasília, 1971, 190 p. RODRIGUES FERREIRA, Alexandre. "Memoria sobre o Peixe Pirá-urucu", in Arch. Mus. Nac. Rio de Janeiro, 12, 1903a, pp. 155-8.

- "Memoria sobre o Peixe Boy e do Uso que lhe Dão no Estado do Grão Pará", in Arch. Mus. Nac. Rio de Janeiro, 12, 1903b, pp. 169-74.

"Memoria sobre Yurara-reté", in Arch. Mus. Nac. Rio de Janeiro, 12, 1903c, pp. 181-86.

."Roteiro das Viagens que Fez pelas Capitanias do Pará, Rio Negro, Mato Grosso e Cuiabá. Alexandre Rodrigues Ferreira, a quem Acompanharão os Desenhistas, Joseph Joachim Freire, Joachim Joseph Codina e o Jardineiro Botanico, Agostinho Joachim do Cabo", in Bol. Mus. Nac. Rio de Janeiro, 9 (2), 1933, pp. 103-18. . "Observações Geraes, e Particulares, sobre a Classe dos Mammaes Observados nos Territorios dos Trez Rios, das Amazonas, Negro e da Madeira: com as Descripções Circunstanciadas, que, de quazi todos Elles, Derão os Antigos, e Modernos Naturalistas, e Principalmente, com a dos Tapuyas", in Rev. Inst. Geogr. Hist. Bahia, 60, 1934, pp. 1-217.

. Viagem Filosofica pelas Capitanias do Grão Pará, Rio Negro, Mato Grosso e Cuiabá. 2 vols. Rio de Janeiro, Conselho Federal de Cultura, 1971.

-Viagem Filosófica ao Rio Negro. Belém, Museu Paraense "Emilio Goeldi”, 1983, 775 p. 
ROZE, J. A. "On the Synonymy and Type Specimens of the Coral Snakes Micrurus corallinus and M. ibiboboca (Marcgravii)", in Copeia (2), 1966, pp. 369-71.

SCHAUENSEE, R. M. de. The Birds of South America and their Distribution. Philadelphia, Academy of Natural Sciences, 1966, xvii +577 p.

SCHIFTER, H. "Johann Natterer und seine ornithologischen Entdeckungen in Brasilien, 18171835”, in Amerika - zur Entdeckung - Kulturpflanzen - lebensraum Regenwald, Kat. O.Ö. Landemus. (NF) 61, pp. 155-78, 1983.

SCHNEIDER, A. "Die Vogelbilder zur Historia Naturalis Brasiliae des Georg Marcgrave", in J. Ornith., 86 (1), 1938, pp. 74-106.

SAINT-HILAIRE. Ver GEOFFROY SAINT-HILAIRE.

SCHADEN, E. Resenha de J. Röder e H. Trimborn, 1954. "Maximilian Prinz zu Wied", in Rev. Ant., 3 (1), 1955, p. 76.

SCHWEIGGER, A. F. "Prodromus monographiae Cheloniorum auctore Schweigger", in Arch. Naturw. Math., 1, 1812, pp. 271-368, 406-58.

SEIBERT, P. "Die Vegetationsgebiete des Reiseweges von J.B.v. Spix und C.F. Ph. v. Martius aus heutiger Sicht", in E. J. Fittkau (ed.), Festschrift zu Ehren von Dr. Johann Baptist Ritter von Spix. Spixiana Suppl., 9, 1983, 441 p., pp. 63-80.

SHERBORN, C. D. Index Animalium sive Index nominorum quae ab A.D. MDCCLVIII generibus et speciebus animalium imposita sunt. Sectio prima, a calendis Januaris, MDCCLVIII usque ad finem Decembris MDCCC. Cambridge (U. K.), Typographia Academica, 1902, lix + 1.195 p.

. Index Animalium sive Index nominum quae ab A.D. MDCCLVIII generibus et speciebus Animalium imposita sunt. Sectio secunda a calendis Lanuariis, MDCCCI usque ad finem Decembris, MDCCCL. 9 vols. London, British Museum (Natural History), 1922.

e B. B. Woodward. "Dates of Publication of the Zoological and Botanical Portions of Some French Voyages - Part II", in Ann. Mag. Nat. Hist., (7) 8, 1901, pp. 161-4, 333-6, 491-4.

SICK, H. "Die Bedeutung von Johann Baptist von Spix für die Erfoeschung der Vogelwelt Brasiliens", in E. J. Fittkau (ed.), Festschrift zu Ehren von Dr. Johann Baptist Ritter von Spix. Spixiana Suppl., 9, 1983, 441 p., pp. 29-31.

. Ornitologia Brasileira. 2 vols. Brasília, Editora UnB/Linha Gráfica Editora, 1984.

SILVA, A. Tavares da. Ver TAVARES DA SILVA, A.

SILVA CARVALHO, J. "A Vinda de Geoffroy Saint-Hilaire a Lisboa”, in Bol. Acad. Sci. Lisboa (N.S.), 2, 1930, pp. 90-903.

SPIX, J. B. Simiarum et Vespertilionum Brasiliensium species novae, ou Histoire Naturelle des Singes et des Chauve-Souris observées et recueillies pendant le voyage dans l'intérieurs du Brésil exécuté par ordre de S. M. le Roi de Bavière dans les années 1817, 1818, 1819, 1820, Publiée par Jean de Spix. Monachii, Franc. Seraph. Hübschmann, 1823, viii + 72 p., 38 pls.

. Avium species novae quas in itinere per Brasiliam annis MDCCCXVII-MDCCCXX jussu et auspiciis Maximiliani Josephi I. Bavariae Regis suscepto collegit et descripsit Dr. J. B. de Spix. Monachii, Franc. Ser. Hübschmann. 1824a, Vol. 1: (8) + 90 p., 91 pls.; Vol. 2: (4) + 85 p., 109 pls. - Animalia nova sive species novae Testudinum et Ranarum quas in itinere per Brasiliam annis MDCCCXVII-MDCCCXX jussu et auspiciis Maximiliani Josephi I. Bavariae Regis suscepto collegit et descripsit Dr. J. B. de Spix. Monachii, Franc. Seraph. Hübschmann, 1824b, 53 p., 17 + 22 pls.

․․ Serpentum Brasiliensium species novae ou Histoire Naturelle des Serpens, recueillies et observées pendant le voyage dans l'intérieur du Brésil dans les années 1817, 1818, 1819, 1820, exécuté par ordre de Sa Magesté le Roi de Bavière, publiée par Jean de Spix, écrite d'après les notes du voyageur par Jean Wagler. Monachii, Franc. Seraph. Hübschmann, 1824c, viii + 75 p., 26 pls.

- Animalia nova sive species novae Lacertarum quas in itinere per Brasiliam annis MDCCCXVII-MDCCCXX jussu et auspiciis Maximiliani Josephi I. Bavierae Regis sucepto collegit et descripsit Dr. J. B. de Spix. Leipsig, T. O. Weigel, 1825, 26 p., 28 pls.

. Selecta genera et species Piscium quos in itinere per Brasiliam annis MDCCCXVIIMDCCCXX jussu et auspiciis Maximiliani Josephi I. Bavariae Regis Augustissimi peracto collegit et pingendos curavit Dr. J. B. de Spix, digessit, descripsit et observationibus anatomicis illustravit Dr. L. Agassiz, praefactus est et edidit itineris socius Dr. C. F. Ph de Martius. Monachii, C. Wolf, 1829, xvi + ii + 136 p., pls 1-76, A-F.

. Species novae Ranarum quas in itinere annis MDCCCXVII-MDCCCXX per Brasiliam

jussu et auspiciis Maximiliani Josephi I. Bavariae Regis Augustissimi suscepto collegit et descripsit Dr. Joannes Bapt. de Spix. Operis a Spixio anno MDCCCXXIV primum editi tabulas revisit, denuo imprimendas et emendatis coloribus imbuendas curavit Dr. Car. Frid. Phil. de Martius. Monachii, Impensis Editoris, 1840a, 29 p., 22 pls.

. Species novae Testudinum quas in itinere annis MDCCCXVII-MDCCCXX per Brasiliam jussu et auspiciis Maximiliani Josephi I. Bavariae Regis Augustissimi suscepto collegit at descripsit Dr. Joannes Bapt. de Spix. Operis a Spixio anno MDCCCXXIV primum editi tabulas revisit, denuo imprimendas et emendatis coloribus imbuendas curavit Dr. Car. Frid. Phil. de Martius. Monachii, Impensis Editoris, $1840 \mathrm{~b}, 24$ p., 17 pls. 
e MARTIUS, C. F. P. von. Reise in Brasilien auf Befehl Sr. Majestät Maximilian Joseph I. Königs von Baiern in den Jahren 1817 bis 1820 gemacht und beschrieben von Dr. Joh. Bapt. von Spix und Dr. Carl Friedr. Phil. von Martius. Vol. 1 (München, 1823, bei M. Lindauer): xiv +412 pp.; Vol. 2 (München, 1828, bei I. J. Lentner): xviii + 413-884; Vol. 3 (München, 1831, beidem Verfasser; Leipzig, in Comm. bei Friedr. Fleischer): 1vi + 885-1.388 + 40 p. Atlas: 41 pls., 12 mapas.

—. Viagem pelo Brasil. Tradução brasileira promovida pelo Instituto Histórico e Geográfico Brasileiro para a comemoração do seu centenário. Tradutora, d. Lucia Furquim Lahmeyer, bibliotecária do Instituto; revisores, o dr. B.F. Ramiz Galvão e o prof. Basilio de Magalhães (que foi também o anotador). Rio de Janeiro, Imprensa Nacional, 1938. Vol 1: xxxv + 389 p.; Vol. 2: 567 p.; Vol. 3: $x x x v+389$ p.

STRAUCH, A. Das zoologische Museum der Kaiserlichen Akademie der Wissenschaften zu St. Petersburg in seinem fünfzigjährigen Bestehen. St. Petersburg, Akademie der Wissenschaften, 1889, iv+ 372 p., pls.

STRESEMANN, E. Die Entwicklung der Ornithologie von Aristoteles bis zur Gegenwart. Berlin, F. W. Peters, 1951, xv + $431 \mathrm{p}$. . Ornithology from Aristotle to the present. Translated by Hans J. and Cathleen Epstein.

Edited by G. William Cottrell. With a foreword and an epilogue on American Ornithology by Ernst Mayr. Cambridge, Massachusetts and London, Harvard University Press, 1975, xii + 432p.

TASTEVIN, C. "Grammatica da Lingua Tupy", in Rev. Mus. Paulista, 13, 1923a, pp. 535-98. "Vocabulario Tupy-Portuguez", in Rev. Mus. Paulista, 13, 1923b, pp. 599-686.

_. "Nomes de Plantas e Animaes em Lingua Tupy", in Rev. Mus. Paulista, 13, 1923c, pp. 687-764.

TAUNAY, A. E. "Jorge Marcgrave, de Liebstadt (1610-1644). Escorço Biográfico", in Comentários a Jorge Marcgrave, Historia Natural do Brasil, 9 v., 1942, pp. i-xxxvi.

TAVARES DA SILVA, A. "O Cientista Luso-brasileiro Dr. Alexandre Rodrigues Ferreira”, in Bol. Soc. Geogr. Lisboa (65) 3-4, 1947, pp. 117-88.

TEROFAL, F. "Die Fischausbeute der Brasilien-Expedition 1817-1820 von J. B. v. Spix und C. F. Ph. v. Martius", in E. J. Fittkau (ed.), Festschrift zu Ehren von Dr. Johann Baptis Ritter von Spix. Spixiana Suppl., 9, 1983, 441 p., pp. 313-7.

THEATRUM RERUM NATURALIUM BRASILIAE. Brasil Holandês. Deutch-Brazil. Vol. 1, Icones Aquatilium, Icones Volatilium (191 p.). Vol. 2. Icones Animalium, Icones Vegetabilium (255 p.). Rio de Janeiro, Editora Index, 1993.

VANZOLINI, P. E. "The Scientific and Political Contexts of the Bavarian Expedition to Brasil. Introduction", in K. Adler (ed.), Herpetology of Brasil, by J. B. von Spix and J. C. Wagler, facsimilar reprint, Society for the Study of Amphibians and Reptiles, 1981, pp. ix-xxix.

- A Supplement to the Ornithological Gazetteer of Brazil. São Paulo, Museu de Zoologia da Universidade de São Paulo, 1992, 252 p.

. "As Viagens de Johann Natterer no Brasil, 1817-1835", in Papéis Avulsos Zool. São Paulo, 38 (3), 1993, pp. 17-60.

. As Viagens de Alexandre Rodrigues Ferreira pelo Brasil, 1783-1791 (no prelo).

e CARVALHO, C. M. "Two Sibling and Sympatric Species of Gymnophthalmus in

Roraima, Brasil (Sauria, Teiidae)”, in Papéis Avulsos Zool. São Paulo, 37 (12), 1991, pp. 173-226. e MYERS, C. W. 'The Herpetological Collection of Maximilian, Prince of Wied-Neuwied (1792-1867), with Special Reference to Brasilian Materials", in Amer. Mus. Novit. (no prelo). VIEIRA, C. O. C. "Lista Remissiva dos Mamíferos do Brasil", in Arq. Zool., S. Paulo, 8 (11), 1995, pp. 341-474.

WAGENER, Z. Zoobiblion, Livro de Animais do Brasil. Tradução de Olivério Pinto e Alfredo de Carvalho. Comentários zoológicos de Olivério Pinto. Comentários botânicos de D. Bento José Pickel, O. S. B. Comentários etnográficos de Egon Schaden. "Selbstbiographie". São Paulo, Brasiliensia Documenta, 1964, 4.443 p.

WAGLER, J. Ver SPIX, J. B., Serpentum Species novae..., 1824c.

WIED, Karl Viktor Prinz zu. "Maximilian Prinz zu Wied, seine Leben und seine Reisen", in

Maximilian Prinz zu Wied, Unveröffentliche Bilder und Handschriften zur Völkerkunde Brasiliens, 1954, pp. 13-25.

WIED-NEUWIED, Maximilian, Prinz zu. "Ueber die Cobra Coral oder Cobra Corass der brasilianer", in Nova Acta. Acad. Caes. Leop.- Carol., 10 (1), 1820, pp. 105-10, 1 pl.

- Reise nach Brasilien in den Jahren 1815 bis 1817. 2 vols. Frankfurt a. M., H. L. Brönner, 1820-21.

. Abbildungen zur Naturgeschichte Brasiliens. Weimar, 1822-31.

. Beiträge zur Naturgeschichte von Brasilien. 4 vols. Weimar, Gr. H. S. priv. LandesIndustrie- Comptoirs, 1825-33.

- - Viagem ao Brasil. Tradução de Edgar Süssekind de Mendonça e Flavio Poppe de Figueiredo, refundida e anotada por Oliverio Pinto. São Paulo, Companhia Editora Nacional (Brasiliana Grande Formato, Biblioteca Pedagógica Brasileira, Série 5, vol. 1), $1940,511 \mathrm{p}$. 